\title{
APLICAÇÃO DE ÁGUA CARBONATADA EM ABOBRINHA CULTIVADA EM SOLO COM E SEM COBERTURA PLÁSTICA
}

\author{
WELLINGTON FARIAS ARAÚJO
}

\footnotetext{
Tese apresentada à Escola Superior de Agricultura "Luiz de Queiroz”, Universidade de São Paulo, para a obtenção do título de Doutor em Agronomia, área de Concentração: Irrigação e Drenagem.
}

P I R A C I C A B A

Estado de São Paulo - Brasil

Janeiro - 2002 


\title{
APLICAÇÃO DE ÁGUA CARBONATADA EM ABOBRINHA CULTIVADA EM SOLO COM E SEM COBERTURA PLÁSTICA
}

\author{
WELLINGTON FARIAS ARAÚJO
}

Engenheiro Agrônomo

Orientador: Prof. Dr. TARLEI ARRIEL BOTREL

Tese apresentada à Escola Superior de Agricultura "Luiz de Queiroz", Universidade de São Paulo, para a obtenção do título de Doutor em Agronomia, área de Concentração: Irrigação e Drenagem.

P I R A C I C A B A

Estado de São Paulo - Brasil

Janeiro - 2002 


\section{Dados Internacionais de Catalogação na Publicação (CIP) DIVISÃO DE BIBLIOTECA E DOCUMENTAÇÃO - ESALQ/USP}

Araújo, Wellington Farias

Aplic ação de água carbonada em a bobrinha cultivada em solo com e sem cobertura plástic a / Wellington Farias Araújo. - - Piracica ba, 2002.

$86 \mathrm{p}$.

Tese (doutorado) - Escola Superior de Agricultura Luiz de Queiroz, 2002. Bibliografia.

1. Abobrinha 2. Dióxido de carbono 3. Imigação porgoteja mento 4. Plastic ultura I. Título

CDD 635.62

"Permitida a cópia total ou parcial deste documento, desde que citada a fonte - $\mathrm{O}$ autor" 
A todos os brasileiros, especialmente

aos que vivem da agricultura.

\section{DEDICO}

Aos meus pais, Benjamim e Diomar (in

memorian), ao meu tio Farias, à minha esposa Rozânia e às minhas filhas Artemize e Vitória.

\section{DEDICO}

A você leitor!!!

OFEREÇO 


\section{AGRADECIMENTOS}

A Deus, que me concedeu o dom da vida.

À Universidade Federal de Roraima (UFRR), que me liberou para cursar este doutorado.

Ao Departamento de Engenharia Rural da Escola Superior de Agricultura "Luiz de Queiroz", pela oportunidade de aprendizagem, pelo convívio e pelo apoio a este trabalho.

À CAPES/PICDT, pela concessão da bolsa de estudo.

À FAPESP, pelo financiamento do projeto de pesquisa, o que resultou nesta tese.

Ao colega de trabalho, Prof. Dr. Regynaldo Arruda Sampaio, pelo apoio manifestado, ainda em Roraima, e que se intensificou durante a realização deste curso.

Ao Prof. Dr. Tarlei Arriel Botrel, pela orientação e, sobretudo, pelos momentos de convívio e pela mostra de simplicidade.

Ao Prof. Dr. Ricardo Ferraz de Oliveira, pelo apoio no empréstimo de materiais para realização deste trabalho e pela sua organização a ser seguida por todos. 
Aos Professores Dr. Rubens Duarte Coelho, Dr. Marcos Vinicius Folegatti, Dr. Sérgio Duarte Nascimento, Dr. José Antônio Frizzone, Dr. Quirino Augusto C. Carmello e Dr. João Tessarioli Neto, pelo apoio e sugestões durante o doutorado.

Aos demais professores da ESALQ, que contribuíram com minha formação acadêmica e não se furtaram a me ajudar durante a realização do curso.

Ao Dr. Antônio Ismael Cardoso, professor da UNESP/Botucatu, pelas informações sobre a cultura da abobrinha.

Em especial, ao colega Thales Vinícius de Araújo Viana e sua esposa, Lúcia, pelo apoio e pela amizade durante o convívio em Piracicaba.

Aos Colegas, Aderson Soares Andrade Júnior, Marco Conceição, Ronaldo Resende e Valdemício Ferreira de Sousa, pela amizade e apoio durante o curso. Aos demais colegas do Curso de Pós-Graduação, Adriana, Alexandre, Almiro, Anderson, Ariolvaldo, Cristina, Ênio, Fátima, Jarbas, Juan, Leonardo, Maurício, Marcelo, Moretti, Quelmo, René Porfiro, Roberto Atarassi, Silvana e Tamara, que me auxiliaram nesse trabalho.

Aos funcionários do departamento de Engenharia Rural da ESALQ, Antônio, César, Hélio e Lino, pela valiosa colaboração.

Finalmente, a todos aqueles que de uma forma ou de outra contribuíram para a realização deste trabalho. 


\section{SUMÁRIO}

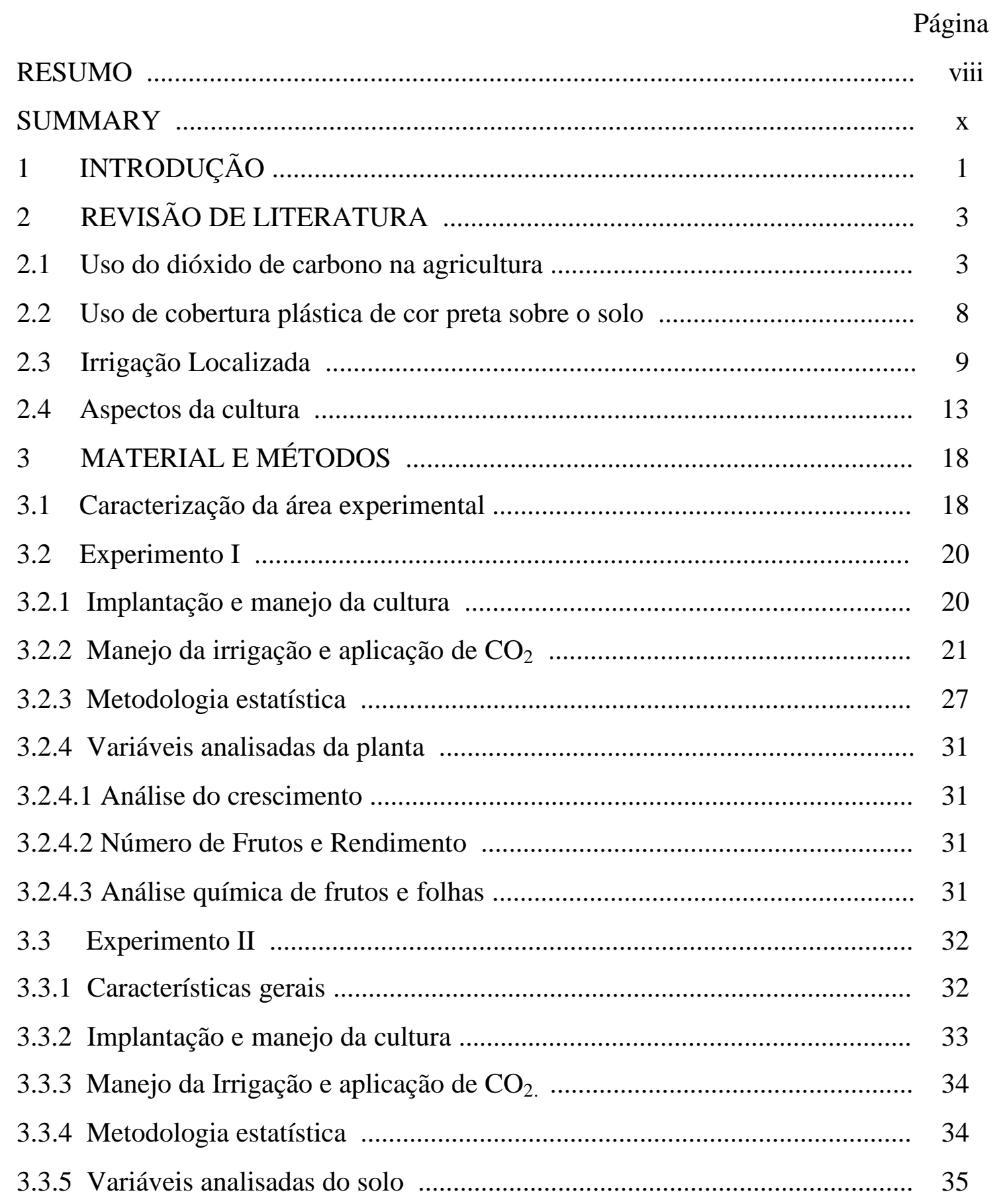


3.3.6 Variáveis analisadas da planta …………………................................ 35

3.3.6.1 Análise do crescimento e da absorção de nutrientes pela cultura ............ 35

3.3.6.2 Número de frutos e rendimento ............................................................. 36

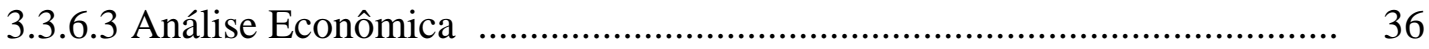

4 RESULTADOS E DISCUSS ÃO......................................................... 38

4.1 Experimento I ............................................................................... 38

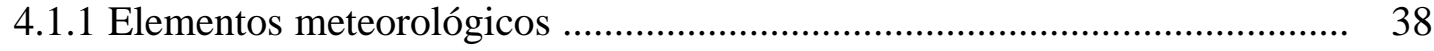

4.1.2 Manejo da irrigação .......................................................................... 40

4.1.3 Uso da água carbonatada ...................................................................... 42

4.1.4 Análise de Crescimento............................................................................. 45

4.1.5 Número de frutos e Rendimento .............................................................. 48

4.1.6 Análise da solução do solo ....................................................................... 51

4.1.7 Análise das Folhas e dos Frutos ........................................................... 52

4.2 Experimento II _......................................................................... 54



4.2.2 Manejo da Irrigação ................................................................................. 56

4.2.3 Uso da água carbonatada .................................................................... 58

4.2.4 Análise de crescimento ......................................................................... 60

4.2.4.1 Área foliar aos 64 DAT .................................................................... 60

4.2.4.2 Massa de material seco aos 64 DAT ………………………………...... 61

4.2.5 Análise da solução do solo ......................................................................... 64

4.2.5 Absorção de nutrientes ............................................................................. 65

4.2.7 Avaliação dos teores de nutrientes nos frutos .............................................. 69

4.2.8 Número de frutos e rendimento .............................................................. 71

4.3 Avaliação econômica …………………………………………………... 74



REFERÊNCIAS BIBLIOGRÁFICAS .......................................................... 78 


\title{
APLICAÇÃO DE ÁGUA CARBONATADA EM ABOBRINHA CULTIVADA EM SOLO COM E SEM COBERTURA PLÁSTICA
}

\author{
Autor: Wellington Farias Araújo \\ Orientador: Prof. Dr. Tarlei Arriel Botrel
}

\section{RESUMO}

A técnica de aplicação de dióxido de carbono na água de irrigação é recente no Brasil, apresentando-se como alternativa promissora para o aumento da produtividade e para a otimização dos equipamentos de irrigação já instalados. Aliado a isso, o uso da cobertura plástica sobre o solo aumenta a temperatura deste e o mantém com umidade elevada por mais tempo, o que pode contribuir para a melhoria na produtividade e na qualidade dos frutos. A cultura da abobrinha de moita (Cucurbita pepo L.) constitui uma opção de plantio para os produtores de olerícolas, por possuir boa aceitação no mercado e poder ser cultivada o ano todo. O objetivo deste trabalho foi estudar o efeito de quatro doses de dióxido de carbono, dissolvido na água de irrigação, e do uso, ou não, da cobertura plástica do solo, sobre o desempenho da cultura da abobrinha. Dois experimentos de campo foram instalados durante o ano de 2000, um com cultivo de maio a julho e outro, de setembro a dezembro na área experimental do Departamento de Engenharia Rural da Escola Superior de Agricultura "Luiz de Queiroz"/ USP em Piracicaba, Brasil. Foi utilizado o delineamento experimental de blocos completos ao acaso, em parcelas subdivididas, com três repetições. Os tratamentos basearam-se na combinação de quatro doses de água carbonatada (parcelas), com e sem cobertura plástica de polietileno preto sobre o solo (subparcelas). Para o primeiro experimento, foram utilizadas as seguintes doses: $0,59,148,274 \mathrm{~kg} \mathrm{ha}^{-1} \mathrm{de}$ $\mathrm{CO}_{2}$, enquanto, para o segundo, foram utilizados: $0,71,199,365 \mathrm{~kg} \mathrm{ha}^{-1} \mathrm{de}^{\mathrm{CO}_{2}}$, aplicados via água de irrigação. No primeiro experimento, com temperaturas médias do 
ar mais amenas, a área foliar, a massa de material seco da parte aérea e das raízes foram influenciadas tanto pelas doses de $\mathrm{CO}_{2}$, quanto pela cobertura plástica do solo. Isso proporcionou incrementos no número de frutos e na produção de abobrinha, sendo ajustados ao fenômeno modelos quadráticos. O maior rendimento foi de $15.435 \mathrm{~kg} \mathrm{ha}^{-1}$, com o uso de $58,4 \mathrm{~kg} \mathrm{ha}^{-1}$ de $\mathrm{CO}_{2}$, associado à cobertura plástica do solo, sendo $65 \%$ superior ao do tratamento-testemunha, que foi de $9.328 \mathrm{~kg} \mathrm{ha}^{-1}$. No segundo experimento, com temperaturas médias do ar mais elevadas, o rendimento e o número de frutos também foram influenciados tanto pela cobertura plástica, quanto pelas doses de $\mathrm{CO}_{2}$ adicionada à água de irrigação. $\mathrm{O}$ maior rendimento foi de $47.098 \mathrm{~kg} \mathrm{ha}^{-1}$, com uma dosagem de $100 \mathrm{~kg} \mathrm{ha}^{-1}$ de $\mathrm{CO}_{2}$ para o solo nu. O conteúdo de nutrientes no fruto apresentou variação de acordo com a idade, sendo que as primeiras colheitas apresentaram teores mais elevados, o que, contudo, não tem relação com a água carbonatada e/ou com a cobertura plástica do solo. Os nutrientes presentes nos frutos em quantidades decrescentes, independente dos tratamentos, foram: $\mathrm{K}>\mathrm{N}>\mathrm{P}>\mathrm{Ca}>$ $\mathrm{Mg}>\mathrm{Fe}>\mathrm{Zn}>\mathrm{Mn}>\mathrm{B}$. Analisado aos 76 dias após o transplantio, o conteúdo de nutrientes em toda a planta foi influenciado pela água carbonatada e pela cobertura do solo. 


\title{
APPLICATION OF CARBONATED WATER IN SUMMER SQUASH CULTIVATED IN SOIL WITH AND WITHOUT PLASTIC MULCH
}

\author{
Author: Wellington Farias Araújo \\ Adviser: Prof. Dr. Tarlei Arriel Botrel
}

\section{SUMMARY}

The technique of carbonated water is recent in Brazil. It is coming as a promising alternative to optimization irrigation equipments already installed. The use of plastic mulch increases soil temperature and soil moisture levels. Both techniques can contribute to improve fruit yield and its quality. Summer squash (Cucurbita pepo L.) is a good option for horticulturists because of its good market acceptance and it can be cultivated all year. Two experiments were conducted under field conditions to determine the effects of four carbon dioxide levels, dissolved in irrigation water, and plastic mulch on summer squash performance. The experiments were installed during the year of 2000, one with cultivation from May to August and other, from September to December in the experimental area at Agricultural Engineering Department of Escola Superior de Agricultura "Luiz de Queiroz"/ USP, in Piracicaba, Brazil. All plots were arranged in a randomized complete blocks in a split plot design with three replications. The treatments were based on the combination of four levels of $\mathrm{CO}_{2}$ in the irrigation water with and without plastic mulch. In the first experiment, the levels of carbonated water used were: $0,59,148,274 \mathrm{~kg} \mathrm{ha}^{-1}$ of $\mathrm{CO}_{2}$. For the second experiment, it was used: 0,71 , $199,365 \mathrm{~kg} \mathrm{ha}^{-1}$ of $\mathrm{CO}_{2}$. In the first experiment, the leaf area, the dry matter above ground and roots were influenced by levels of $\mathrm{CO}_{2}$ applied in the water and plastic 
mulch. They influenced the summer squash fruits number and fruit yield. Quadratic models were fitted to the phenomenon. The highest yield was $15,435 \mathrm{~kg} \mathrm{ha}^{-1}$ applying $58 \mathrm{~kg} \mathrm{ha}^{-1}$ of $\mathrm{CO}_{2}$ associated with plastic mulch. In this case, the yield was $65 \%$ greater than control treatment. In the second experiment, the fruits number and the fruit yield were both influenced by levels of carbonated water and plastic mulch. However, the highest fruit yield was $47,098 \mathrm{~kg} \mathrm{ha}^{-1}$, and it was obtained applying $100 \mathrm{~kg} \mathrm{ha}^{-1}$ of $\mathrm{CO}_{2}$ in a bare soil. The nutrients concentration in the fruits varied according to the age, without any relationship with the treatments. The nutrients order in the fruits was the following: $\mathrm{K}>\mathrm{N}>\mathrm{P}>\mathrm{Ca}>\mathrm{Mg}>\mathrm{Fe}>\mathrm{Zn}>\mathrm{Mn}>\mathrm{B}$. At 76 days after transplant, the nutrients content in the plant was influenced by carbonated water and plastic mulch. 


\section{INTRODUÇÃO}

A abobrinha, designação dada ao fruto de cultivares de abóbora pertencentes às espécies Cucurbita pepo e C. moschata, apresenta uma importância econômica considerável, principalmente no centro sul do país (Camargo, 1981). As vantagens do seu cultivo são o ciclo curto e a possibilidade do plantio ao longo de todo o ano (Filgueira, 2000).

As hortaliças constituem um grupo de plantas com características de cultivo intensivo do solo, com dois ou três ciclos por ano, requerendo irrigação e o emprego de fertilizantes. Seus preços de mercado apresentam variações sazonais, podendo ser agregados valores, como modificações na embalagem de comercialização e a melhoria na qualidade dos produtos, aumentando, assim, a capacidade de retorno do investimento.

A irrigação pode viabilizar uma produção contínua em ambientes abertos e a fertirrigação está sendo difundida no campo, pela sua praticidade e eficiência. $O$ uso da cobertura plástica do solo com polietileno ("mulch") tem sido recomendado para uma série de culturas e já faz parte de certos pacotes tecnológicos, juntamente com a irrigação, como para a cultura do morango.

Nos Estados Unidos da América, um dos maiores produtores de abobrinha, o uso de mulch, a irrigação e a fertirrigação são práticas essenciais para se obterem bons rendimentos e melhoria na qualidade do produto (Bhella \& Kwolek, 1984; Lamont Jr., 1996).

A aplicação de $\mathrm{CO}_{2}$, via água ou via ar, tem sido testada com relativo sucesso em hortaliças, em frutíferas e em plantas ornamentais. Embora não seja uma técnica nova, já que os primeiros trabalhos de utilização de $\mathrm{CO}_{2}$ na agricultura datam do 
começo do século XX, sua adoção, para uso geral, ainda não tem sido recomendada. A utilização dessa técnica, em ambiente protegido, se está tornando cada vez mais viável economicamente. Porém, em condições de campo sua utilização ainda é questionada (Moore, 1990).

O objetivo deste trabalho foi estudar os efeitos de quatro doses de dióxido de carbono, injetadas na água de irrigação, associadas à técnica da cobertura plástica sobre o solo (mulch) na cultura da abobrinha, buscando-se a melhoria na qualidade dos frutos e o aumento na produção. Como objetivo secundário, buscou-se conhecer a absorção de nutrientes para a referida cultura, o que pode auxiliar no manejo da fertirrigação.

Consideraram-se as seguintes hipóteses:

- o uso de água carbonatada aumenta a absorção de nutrientes pela planta e promove aumento na produtividade;

- o uso da cobertura plástica no solo aumenta a absorção de nutrientes pela planta e promove aumento na produtividade;

- é viável economicamente a aplicação do gás carbônico via água de irrigação e o uso da cobertura plástica;

- as concentrações de $\mathrm{CO}_{2}$ no ar, no dossel da planta, são modificadas pelo uso do $\mathrm{CO}_{2}$ aplicado via água de irrigação, sendo maior o incremento com a utilização da cobertura plástica sobre o solo (mulch);

- a taxa de absorção de nutrientes pela cultura é alterada com o uso de água carbonatada, associado à cobertura plástica sobre o solo (mulch). 


\section{REVISÃO DE LITERATURA}

\subsection{Uso do dióxido de carbono na agricultura}

A concentração de dióxido de carbono na atmosfera aumentou em cerca de 30\% durante os últimos 200 anos, passando de $280 \mathrm{mg} \mathrm{L}^{-1}$ para mais de $360 \mathrm{mg} \mathrm{L}^{-1}$. Estima-se que, no futuro, essa concentração atingirá entre 600 e $800 \mathrm{mg} \mathrm{L}^{-1}$ (Kimball et al., 1994). O aumento da concentração de $\mathrm{CO}_{2}$ na superfície tem provocado alterações temporais e espaciais nas precipitações e na evaporação, através do chamado efeito estufa (Amthor, 1998). Esse fato tem despertado nos cientistas, o desejo de conhecer melhor o desempenho das culturas, quando submetidas a ambientes enriquecidos com $\mathrm{CO}_{2}$, buscando-se fazer inferências sobre a qualidade dos produtos e o seu rendimento nessas atmosferas modificadas.

Uma das primeiras referências ao enriquecimento do ambiente pelo uso do $\mathrm{CO}_{2}$ para as plantas, data de 1918, sendo a técnica denominada de fertilização aérea com dióxido de carbono (Moore, 1990). As fontes de $\mathrm{CO}_{2}$ utilizadas eram o querosene e o propano, cuja combustão no interior de estufas gerava subprodutos altamente tóxicos para os vegetais, como o propileno, o etileno, o monóxido de carbono e o óxido de

enxofre. A utilização de $\mathrm{CO}_{2}$ puro, o advento de equipamentos eficazes de medição e de métodos mais eficientes de carbonatação renovaram o interesse por essa linha de pesquisa.

A absorção de $\mathrm{CO}_{2}$ pela planta é realizada quase totalmente por difusão, através dos estômatos nas folhas. O suprimento de água, de luz em quantidade e em qualidade, de temperatura, de disponibilidade de nutrientes para a planta e de concentração de $\mathrm{CO}_{2}$ atmosférico são os principais fatores ambientais que interferem na 
abertura e no fechamento dos estômatos e, conseqüientemente, nos processos de trocas gasosas e de fotossíntese (Hall \& Rao,1980). A absorção de carbono pode ser realizada também pelas raízes e tem sido relatada por vários autores em diversas culturas (Arteca et al., 1979; Arteca \& Poovaiah, 1982; Baron \& Gorski, 1986).

Metodologias têm sido desenvolvidas para estudar as respostas de plantas cultivadas e de comunidades vegetais ao incremento no $\mathrm{CO}_{2}$ atmosférico. $\mathrm{O}$ principal problema é a simulação de um ambiente de exposição no qual somente a concentração de $\mathrm{CO}_{2}$ seja alterada (Jones, 1993).

A partir de 1980, a maioria das pesquisas foram conduzidas em ambientes controlados, incluindo-se o uso de cubetas para folhas e o suprimento de $\mathrm{CO}_{2}$ em câmaras de crescimento e em casas-de-vegetação, com clima modificado. As cubetas permitem determinar as taxas de intercâmbio de $\mathrm{CO}_{2}$ ou $\mathrm{O}_{2}$ e água, porém essa metodologia não possibilita o controle de longa duração do ambiente em torno das plantas (Allen et al., 1992).

Elevados níveis de $\mathrm{CO}_{2}$ podem ser aplicados diretamente em casas-devegetação, e, associados a um adequado suprimento hídrico e nutricional, otimizam a produção intensiva de hortaliças e frutas (Allen et al., 1992).

Outro sistema desenvolvido para pesquisar plantas com altos níveis de $\mathrm{CO}_{2}$ são as câmaras de topo aberto. Estudos realizados com essas câmaras tomaram impulso significativo nas duas últimas décadas, com o objetivo de avaliar os efeitos do gás sobre as respostas fisiológicas e a produtividade em diferentes espécies vegetais (Allen, 1990; Drake et al., 1998). Praticamente todas as espécies vegetais têm sido expostas a elevados níveis de $\mathrm{CO}_{2}$ nesse tipo de câmara, ou sob outra forma, e, de modo geral, apresentaram incremento na taxa de fixação do carbono, na biomassa da parte aérea e das raízes e na produção (Idso \& Idso, 1994).

Reinert et al. (1997) obtiveram aumentos de $24 \%$ na produtividade do tomateiro, com tratamentos com até $675 \mu \mathrm{mol} \mathrm{L} \mathrm{L}^{-1}$ de $\mathrm{CO}_{2}$, em ambientes controlados.

Vessey et al. (1990) estudaram o efeito da elevação da concentração do $\mathrm{CO}_{2}$ sobre a soja. Os autores observaram incrementos na matéria seca de cerca de 31 e $45 \%$, para os níveis de $\mathrm{CO}_{2}$ de 650 e $900 \mu \mathrm{L} \mathrm{L}^{-1}$, respectivamente. A elevação na 
concentração de $\mathrm{CO}_{2}$ também ocasionou um aumento nos níveis de $\mathrm{N}$ total e na área foliar, mas não no número de folhas. A resistência estomática cresceu e o sistema radicular apresentou diminuição.

Em experimento de campo, Hartz et al. (1991) estudaram o efeito da aplicação de $\mathrm{CO}_{2}$ via ar, sobre a abobrinha. Os autores observaram produções até $20 \%$ superiores às das plantas submetidas ao tratamento sem o uso de gás carbônico, com um aumento de custos inferior a $10 \%$.

Independente do modo de aplicação de $\mathrm{CO}_{2}$, pesquisas têm buscado conhecer o comportamento das culturas frente ao meio, com concentração de gás carbônico elevada, ou modificada pelo uso do gás. Em geral, o aumento nos níveis de $\mathrm{CO}_{2}$ resulta em um enriquecimento do ar, levando a um aumento na fotossíntese (Harper et al., 1973), no crescimento de raízes (Chaudhuri et al., 1990), no crescimento das plantas (Vessey et al.,1990), na alteração da razão raiz/parte aérea (Mudrik et al., 1997) e no rendimento das culturas (Hopen \& Oebker, 1975; Idso \& Idso ,1994).

Idso \& Idso (1994) apresentaram uma ampla revisão dos trabalhos de pesquisa feitos nos 10 anos anteriores: com aplicação de $\mathrm{CO}_{2}$, observaram aumento no crescimento e na produção de plantas, sobretudo em plantas submetidas a algum tipo de estresse.

Alternativas para a aplicação do $\mathrm{CO}_{2}$ sobre a cultura têm sido estudadas. Nakayama \& Bucks (1980) aplicaram água carbonatada pelo sistema subsuperficial em trigo e obtiveram aumento de $20 \%$ na produção e uma redução no $\mathrm{pH}$ do solo em 1,5 unidade.

Guri et al. (1999) aplicaram uma concentração de $\mathrm{CO}_{2}$ de 400 ppm em solução nutritiva e obtiveram aumentos de $10 \%$ na produção de pimentão, com incremento na área foliar e no peso dos frutos.

D`Andria et al. (1993) estudaram as modificações no solo e no estado nutricional do tomateiro, quando a irrigação foi feita com água carbonatada. Os autores observaram um conteúdo maior de cátions na planta. A concentração de nutrientes no fruto foi se modificando de acordo com o período de colheita. Inicialmente, conteúdos maiores de $\mathrm{Zn}, \mathrm{Ca}, \mathrm{Fe}, \mathrm{Mn}$ foram observados nos frutos dos tratamentos com água 
carbonatada. Posteriormente, os teores de $\mathrm{Zn}$ e Mn foram similares aos da testemunha, enquanto $\mathrm{Cu}$ e Fe foram menores nas últimas colheitas. Para a mesma cultura, Novero et al. (1991) observaram aumentos significativos no teor de $\mathrm{Zn}$ presente nas folhas, tendo a produção total aumentado em 15,9\%, com a utilização de água carbonatada. Mauney \& Hendrix (1988) reportaram que o $\mathrm{Zn}$ e o Mn apresentaram concentrações maiores nas plantas de algodão irrigadas com água carbonatada.

Normalmente, os trabalhos científicos têm analisado o efeito de ambientes modificados sobre a cultura, comparando-se um meio modificado com o uso do $\mathrm{CO}_{2}$ com outro sem a adição do gás. Raros são os experimentos que têm trabalhado com diferentes doses do gás, principalmente adicionado via água de irrigação.

Storlie \& Heckman (1996a) analisaram em experimento de campo, o efeito de doses de $\mathrm{CO}_{2}\left(0 ; 0,396 ; 0,804\right.$ e 1,2 $\left.\mathrm{g} \mathrm{L}^{-1}\right)$ na água de irrigação sobre a cultura de pimentão. Os autores constataram uma pequena elevação nos níveis de $\mathrm{CO}_{2}$ do ar durante a irrigação, porém não obtiveram aumentos de produção ou alteração na qualidade do fruto. Também sugeriram que a associação entre o sistema de irrigação localizada, utilizando água carbonatada e mulch, promovem manutenção do $\mathrm{CO}_{2}$ no dossel da planta por mais tempo e aumentos na longevidade das raízes, pela inibição do etileno. Sobre os teores de $\mathrm{CO}_{2}$ no dossel da cultura, observa-se que os ventos promovem o arraste do gás, fazendo com que o ar praticamente não mostre elevações nos teores de $\mathrm{CO}_{2}$ em experimentos com o gás. Rezende (2001) comenta, em seu experimento com aplicação de $\mathrm{CO}_{2}$ via ar, que, para elevação dos teores do gás em ambiente protegido, foi necessário que o local permanecesse fechado; caso contrário, as concentrações de $\mathrm{CO}_{2}$ no ambiente interno permaneciam semelhantes às do ambiente externo.

Hartz \& Holt (1991) estudaram o efeito de doses de $\mathrm{CO}_{2}(0 ; 0,5$ e $1,0 \mathrm{~g} \mathrm{~L}^{-1}$ ) na água de irrigação sobre as plantas de tomate e pepino e não constataram aumentos de produção em nenhuma delas.

Ibrahim (1992) avaliou o efeito de doses de $\mathrm{CO}_{2}(0 ; 50 ; 150 ; 200 \mathrm{ppm})$, via água de irrigação, sobre pepino, verificando um efeito linear positivo entre doses e 
produção. Houve uma melhoria na qualidade do fruto e um maior acúmulo de $\mathrm{P}, \mathrm{Zn}, \mathrm{Mn}$ e Fe na planta.

A aplicação de $\mathrm{CO}_{2}$, via água de irrigação, apresenta uma vantagem adicional: a maximização do uso do sistema de irrigação, tal como ocorre na quimigação, onde fungicidas, inseticidas, herbicidas são vinculados à água de irrigação, de forma que, em uma única operação, o agricultor possa fazer uso de vários produtos, visando à maior produtividade e à redução dos custos.

Storlie \& Heckman (1996b) sugerem que o uso da água carbonatada não tem sido ainda recomendado comercialmente, devido às poucas pesquisas realizadas em campo e ao desconhecimento de certos mecanismos de ação, que promovem resultados diversos, dependendo das condições ambientais.

Vindo de encontro a essa idéia, Hartz \& Holt (1991) estudaram o efeito do $\mathrm{CO}_{2}$, aplicado via água de irrigação, sobre as plantas de tomateiro e da abóbora em campo. Os autores não observaram efeitos significativos sobre as produções e sugeriram que isso ocorreu devido à interferência de fatores ambientais sobre os tratamentos com água carbonatada.

No Brasil, Pinto (1997) obteve um incremento de $27,3 \%$ na produtividade do melão cultivado em estufa, com a aplicação diária de $\mathrm{CO}_{2}$ via água de irrigação, sendo utilizados, no total, cerca de $50 \mathrm{~kg} \mathrm{ha}^{-1}$ do gás. Cararo (2000) trabalhou com aplicação de $\mathrm{CO}_{2}$, via água de irrigação, em ambiente protegido na cultura do tomateiro e obteve um incremento de $8,7 \%$ na produção, de $11,5 \%$ no peso dos frutos de tamanho pequeno e de $7,8 \%$ no material seco dos frutos.

Storlie \& Heckman (1996b) citam os possíveis mecanismos que levam a cultura ao incremento da produção, quando se trabalha com água carbonatada: i) incremento na absorção de alguns elementos pela planta; ii) enriquecimento do sistema solo-ar com $\mathrm{CO}_{2}$, inibindo a atividade de etileno e melhorando a atividade do sistema radicular; iii) absorção direta de $\mathrm{CO}_{2}$ pela raiz; iv) enriquecimento em torno da planta com $\mathrm{CO}_{2}$, estimulando à fotossíntese. 


\subsection{Uso de cobertura plástica de cor preta sobre o solo}

Em relação à cobertura plástica do solo, Makishima \& Miranda (1992) comentam que a evapotranspiração pode ser reduzida de 5 a $10 \%$ principalmente na fase inicial da cultura, quando a evaporação tem predomínio sobre a transpiração. Segundo os autores, a cobertura plástica também tem influência sobre a distribuição das raízes, estimulando-as a serem mais superficiais, possivelmente pelo maior acúmulo de umidade na superfície.

A temperatura na camada superficial do solo fica cerca de $5^{\circ} \mathrm{C}$ mais elevada com a cobertura plástica em relação ao solo nu, propiciando uma maior absorção de água e de nutrientes e, conseqüentemente, um maior crescimento em períodos de baixas temperaturas (Bhella \& Kwolek, 1984; Abdul-Baki et al., 1992). Geralmente, a temperatura média diária do ar, medida $5 \mathrm{~cm}$ acima da cobertura plástica, é até $2^{0} \mathrm{C}$ mais elevada em relação à temperatura do ar no solo sem cobertura (Tsekleev et al., 1993).

Bhella (1988) comenta que há uma redução na competição por luz e nutrientes entre a planta cultivada e as ervas daninhas, e uma menor lixiviação de nutrientes, principalmente $\mathrm{N}$ e K. O autor também observou maiores concentrações de Zn e Ca no pecíolo da melancia cultivada sob cobertura plástica do solo, em relação àquela cultivada em solo nu. Sweeney et al. (1987) reportaram aumento de teores de N em tomateiro cultivado em solo coberto com polietileno. Há, ainda, relatos da diminuição da incidência de certas doenças, como a murcha de esclerócio e de pragas do solo (Garnaud, 1974) .

Sanders (1996) comenta que nas culturas de tomate, pimentão, abobrinha, e berinjela, têm sido utilizado o mulch, com aumento significativo na produção, precocidade e melhoria na qualidade dos frutos. $\mathrm{O}$ autor cita algumas va ntagens do uso do plástico, tais como: aumento na temperatura do solo, redução na compactação do solo, redução na lixiviação de nutrientes, redução na evaporação, antecipação na colheita, produção mais limpa e aumento do crescimento. Há algumas desvantagens, tais como aumento no custo de produção, maior cuidado no manejo diário, para se ter maior 
durabilidade do plástico, e aumento nos custos para remoção, quando for necessário um novo preparo do solo.

Lamont Jr. (1996) comenta sobre uma melhor eficiência do uso de água e da absorção de nutrientes. O autor sugere que o uso do plástico induz a adoção de outras tecnologias, como o uso da irrigação localizada e da fertirrigação, incrementando a produção.

Mormeneo \& Cantamutto (1999) observaram aumentos significativos nas temperaturas médias com o uso do mulch preto, em relação ao solo nu, da ordem de $3,7^{\circ} \mathrm{C}$ a $4,1^{\circ} \mathrm{C}$ durante o verão na Argentina. Esses autores observaram precocidade no desenvolvimento de diferentes culturas hortícolas. Outros autores também verificaram antecipação no ciclo e na produção com o uso da cobertura plástica do solo (Bhella \& Kwolek, 1984; Bhella, 1988; Ibarra et al., 2001).

\subsection{Irrigação Localizada}

No Brasil, dentre os métodos de irrigação pressurizados, a aspersão convencional predomina sobre os demais nas áreas irrigadas, porém a irrigação por gotejamento vem ganhando espaço no Brasil e em todo o mundo. Estima-se que nos

próximos dez anos não só as novas áreas irrigadas utilizarão esse método, como haverá uma reconversão de $30 \%$ das áreas irrigadas por aspersão, para localizada, ou seja, por gotejamento e microaspersão (Christofidis, 2001).

Bernardo (1995) cita as vantagens do sistema localizado, apresentando maior eficiência no uso da água, na adubação, no controle fitossanitário e mo uso de mão-de-obra. Silva \& Marouelli (1998) comentam, entretanto, que nenhum método é considerado ideal, devendo sua escolha ser baseada na viabilidade técnica e econômica do projeto para cada caso específico.

O princípio básico da irrigação é suprir de água o sistema solo-planta, de modo a satisfazer a demanda evapotranspiratória da cultura. Nos sistemas de irrigação por gotejamento, o turno de rega é pequeno, o que mantém a umidade do solo na zona radicular próxima à "capacidade de campo" e, em conseqüência, a planta transpira 
continuamente em seu potencial máximo, o que é uma característica peculiar deste método de irrigação (Bernardo, 1995).

O termo "capacidade de campo" representa a quantidade de água retida pelo solo, depois que o excesso se tenha drenado livremente e a taxa de movimento descendente se tenha reduzido acentuadamente; todavia Reichardt (1988) acrescenta que esse é um processo dinâmico do solo, e não uma característica intrínseca de sua matriz. Até o presente momento, ainda não há um consenso quanto à conceituação de capacidade de campo e das medidas que possam representá-la, porém valores clássicos citam tensões de água de $10 \mathrm{kPa}$ a $33 \mathrm{kPa}$, já, trabalhos recentes recomendam o uso de tensões de $6 \mathrm{kPa}$ a $10 \mathrm{kPa}$ (Reichardt, 1988; Souza \& Reichardt, 1996; Silva \& Marouelli ,1998).

Dois métodos básicos são recomendados para o manejo nas irrigações por gotejamento: um baseado no solo e outro, no clima, podendo-se ainda fazer uma combinação entre ambos (Bernardo, 1995; Hartz, 1996). Há métodos que utilizam a planta, como no uso da termometria e do fluxo de seiva; entretanto são mais restritos à pesquisa.

Segundo Bernardo (1995), em sistemas de irrigação localizados, já se tornou comum o uso da irrigação com base no clima, com o uso da evaporação do Tanque Classe A. Tal método é bastante utilizado e recomendado pela FAO, embora existam inúmeros outros, com medição direta (lisímetro e balanço hídrico do solo), ou com a estimativa da lâmina de irrigação, utilizando-se elementos meteorológicos (Doorenbos \& Pruitt, 1997). O tanque classe A fornece uma medida do efeito integrado da radiação solar, do vento, da temperatura e da umidade relativa do ar sobre a evaporação de uma superfície livre de água. De modo similar, as plantas respondem a essas variáveis climáticas, embora muitos fatores podem produzir efeitos diferentes na transpiração da cultura.

A relação entre a evapotranspiração de uma cultura (ETc) e a estimada pelo tanque classe A é dada pela equação 1 ( Doorenbos \& Pruitt, 1997):

$$
\mathrm{ETc}=\mathrm{ECA} . \mathrm{Kp} . \mathrm{Kc}
$$


em que: ECA é a evaporação ocorrida pelo tanque classe A; Kp e Kc são coeficientes de ajustes do tanque e da cultura, respectivamente.

O Kp depende basicamente das condições de bordadura em volta do tanque e de elementos do clima, tais como umidade relativa e velocidade do vento. $\mathrm{O}$ valor de Kp é freqüentemente adotado como igual a 0,7; enquanto Kc depende da cultura a ser irrigada e seu estádio de desenvolvimento (Pereira et al. , 1997). Os valores de Kc devem servir apenas como referência, uma vez que eles podem variar com a cultivar, com as condições locais de plantio, o solo, o clima, os tratos culturais e o manejo da irrigação (Hartz, 1996).

Segundo Bernardo (1995), nem toda superfície do solo é molhada em sistemas de irrigação localizados, resultando numa menor quantidade de água evaporada dessa superfície. Assim, costuma-se introduzir, na equação 1, um coeficiente de redução $(\mathrm{Kr})$, baseado na fração da área ocupada pela cultura em relação ao seu espaçamento, resultando na equação 2:

$$
\mathrm{ETc}=\mathrm{Kp} \cdot \mathrm{Kc} \cdot \mathrm{Kr} \cdot \mathrm{ECA}
$$

Várias são as fórmulas para a estimativa do coeficiente de redução $(\mathrm{Kr})$, sendo as mais utilizadas a de Pizarro (1986) e a de Keller \& Bliesner (1990), equações 3 e 4, respectivamente:

$$
\begin{aligned}
& \mathrm{Kr}=0,1+\mathrm{GC} \\
& \mathrm{Kr}=0,1 .(\mathrm{GC})^{0,5}
\end{aligned}
$$

nelas GC representa a estimativa da taxa de projeção da copa.

O manejo da irrigação pode ser feito via solo, principalmente por meio de tensiômetros, sensores de umidade, TDR ou sonda de nêutrons. Os tensiômetros apresentam vantagens sobre os demais, no seu manuseio e instalação, além de serem de 
baixo custo. Porém apresentam como desvantagem principal o fato de refletirem uma leitura pontual, portanto muito influenciada pela variabilidade espacial dos solos (Gomide, 1998).

As olerícolas são culturas geralmente de ciclo curto, bastante dependentes do ambiente e susceptíveis às deficiências hídricas, possibilitando pouca margem de erro para que o manejo não se torne inadequado, com reflexos negativos na produção. Dessa forma, a irrigação é fundamental como fator de diminuição de riscos de rendimentos e de melhoria na qualidade do produto. Nessas culturas, quando se utiliza cobertura plástica sobre o solo (mulch), é usualmente empregada a irrigação localizada por gotejamento, para se obter o benefício máximo dos métodos (Lamont Jr., 1996); associada a essas práticas de cultivo, está a fertirrigação (Bhella, 1988; Hartz, 1996).

Derwerken \& Wilcox-Lee (1988) avaliaram o efeito de vários métodos de irrigação, com e sem o uso da cobertura plástica do solo, na cultura do pimentão. Os autores verificaram produção máxima, quando combinaram irrigação localizada com a cobertura do solo, sendo que as tensões foram sempre maiores que $10 \mathrm{kPa}$ a $15 \mathrm{~cm}$ de profundidade.

Locascio \& Smajstrla (1996) estudaram o efeito da reposição de água ao solo baseada em frações da água evaporada do tanque classe A, em três anos de cultivo com tomateiro. Durante o período seco, produções maiores foram obtidas com irrigações de 0,75 e 1,0 vez a leitura do tanque. Para o período úmido, não foram observadas diferenças significativas entre os tratamentos.

Especificamente para abobrinha, Bhella \& Kwolek (1984) estudaram o efeito da irrigação localizada e da cobertura plástica por dois anos. A cultura apresentou desenvolvimento melhor, antecipação no ciclo e aumento significativo na produção. Os autores atribuíram os resultados ao melhor controle das ervas daninhas, à redução na perda de nutrientes, à melhor retenção do calor e da umidade nos tratamentos com mulch. 


\subsection{Aspectos da cultura}

As cucurbitáceas incluem 118 gêneros e cerca de 825 espécies, valorizadas devido a seu valor alimentício e culinário, principalmente algumas espécies do gênero Cucurbita (abóbora, abobrinha), Cucumis (melão, pepino), Sechium (chuchu) e Citrullus (melancias) (Paris, 1996).

O principal produto olerícola das plantas do gênero Cucurbita é o fruto, podendo ser consumido na forma imatura (abobrinha) cozida, como salada, ou na forma madura (abóbora) cozida com açúcar (doces) ou sal (quibebes), podendo-se também comer refogados os ponteiros de ramas (cambuquira) e as flores empanadas. As sementes torradas são consideradas suplementos protéicos, contendo entre 30 e $37 \%$ de proteína bruta (Informe Agropecuário, 1982).

A abobrinha é a designação dada ao fruto de cultivares de aboboreira, pertencentes às espécies Cucurbita pepo L., com hábito de crescimento moita, ou $C$. moschata Duch, com hábito de crescimento rasteiro. A cultura apresenta mportância econômica, principalmente no centro sul do Brasil (Camargo, 1981). As grandes vantagens do seu cultivo são o ciclo curto e a possibilidade do plantio ao longo de todo o ano (Filgueira, 2000). A abobrinha possui frutos com formato cilíndrico, levemente afilados, na direção do pedúnculo. No ponto comercial, suas dimensões variam entre 15 e $20 \mathrm{~cm}$ de comprimento e de 4 a $6 \mathrm{~cm}$ de diâmetro, pesando de 200 a $250 \mathrm{~g}$. A cultivar do tipo italiano, caserta, é a mais tradicional representante do grupo, com frutos de formato cilíndrico/cônico e coloração verde clara com estrias verde escuras. O início da colheita ocorre entre 45 e 60 dias após o plantio, podendo prolongar-se por mais 60 dias. Ressalta-se, ainda, que colheitas freqüentes favorecem a produtividade (Filgueira, 2000).

O gênero Cucurbita é nativo do continente americano (Estados Unidos e México). O material foi levado à Europa, posteriormente, sendo melhorado em termos de precocidade e de produtividade. Hoje, esse continente responde por 1/3 da produção mundial. A espécie Cucurbita pepo é representada por seis grupos, baseados nas 
dimensões do fruto, sendo um dos principais grupos zucchini, cujo termo é o diminutivo do italiano zucca, país onde a cultura ganhou grande expressividade (Paris, 1996).

No Brasil, segundo o Censo Agropecuário de 1996, foram produzidas cerca de 68.833,9 t de abobrinha, sendo a região Sudeste a responsável por cerca de $72 \%$ da produção nacional (IBGE, 2001). O Estado de São Paulo é um dos maiores produtores dessa hortaliça, endo produzido, em 1999, cerca de 37.140 t do produto numa área cultivada de 3.781 ha, ocupando o quinto lugar em área cultivada dentre os frutos olerícolas naquele ano (Camargo Filho \& Mazzei, 2000).

O cultivo das hortaliças no Estado de São Paulo, nos anos noventa, expandiu em $41 \%$ sua área e aumentou em $53 \%$ a produção. Dentre as hortaliças, o grupo dos frutos olerícolas, onde se insere a abobrinha, apresenta um consumo relativamente constante ao longo do ano, mas tem uma menor produção no outono e inverno, devido à redução na área de cultivo, gerando assim um aumento dos preços nesse período (Camargo Filho \& Mazzei, 2000). Cardoso (1998) afirma que a abobrinha atinge maior preço em fevereiro e no período de maio a setembro, com valores mais que o dobro dos praticados em outubro/novembro.

Quanto ao rendimento, Silva et al. (1988), em Viçosa, MG, obtiveram 18,08 $\mathrm{tha}^{-1}$, considerando uma população de 12.500 plantas de abobrinha tipo caserta, num ciclo de 69 dias. Lunardi et al. (1999) obtiveram produtividade de $28 \mathrm{t} \mathrm{ha}^{-1}$ para um ciclo de 70 dias nas condições de Botucatu, SP. Maroto (1995), na Espanha, comentou que, sob condições ótimas de cultivo, podem ser obtidas de $30 \mathrm{t} \mathrm{ha}^{-1}$ a $50 \mathrm{t} \mathrm{ha}{ }^{-1}$, podendo, em alguns casos, ser atingida a produção de $100 \mathrm{t} \mathrm{ha}^{-1}$, sendo primordiais para a obtenção de produções elevadas as condições ambientais e fitossanitárias. A literatura cita vários trabalhos que contabilizam a produção por prazo de, no máximo, 30 dias de colheita (Stansell \& Smittle, 1992; Hartz et al., 1991), embora também sejam encontrados outros que adotam períodos maiores (Bhella \& Kwolek, 1984; Clough et al., 1992). Isso dificulta a comparação de rendimentos de abobrinha entre trabalhos científicos, quando não se conheçe por quantos dias a produção foi colhida. Todavia Filgueira (2000) sugere bons rendimentos entre 10 e $20 \mathrm{t} \mathrm{ha}^{-1}$. 
Em termos de temperatura, Serrana $^{1}$ (1979), citado por Maroto (1995), coloca como $8^{\circ} \mathrm{C}$ a temperatura basal da cultura, sendo a temperatura mínima para a germinação de $15,5^{\circ} \mathrm{C}$ e a temperatura ótima para o cultivo, entre $25^{\circ} \mathrm{C}$ e $35^{\circ} \mathrm{C}$. Já Lorenz \& Maynard (1988) sugerem como faixa de temperatura ideal entre $18{ }^{\circ} \mathrm{C}$ e $24{ }^{\circ} \mathrm{C}$. Filgueira (2000) afirma que a cultura produz melhor sob temperaturas amenas, não tolerando geadas.

Para um manejo adequado da irrigação, é necessário conhecerem-se algumas características da cultura, tais como a profundidade do sistema radicular e seu coeficiente de cultivo $(\mathrm{Kc})$.

A abobrinha apresenta sistema radicular superficial e necessita de irrigações freqüentes para ter bons rendimentos (Filgueira, 2000). Fontes \& Lima (1993) comentam que o sistema radicular é do tipo fasciculado, concentrado na porção superficial, apresentando, entretanto, grande crescimento lateral. A falta de água, além de diminuir a produção, causa deformação no fruto (Trani \& Raij, 1996). Stansell \& Smittle (1992) observaram bons rendimentos, quando as plantas foram submetidas a potenciais mátricos do solo entre a capacidade de campo ( $8 \mathrm{kPa}$ ) e $25 \mathrm{kPa}$. Cocucci et al. (1976) sugerem que o crescimento do fruto é controlado diretamente pela disponibilidade de água.

Para a região de Botucatu, SP, Klosowski et al. (1999) propuseram os coeficientes de cultivo (Kc) para abobrinha (Cucurbita pepo L. cv. Caserta), utilizando um conjunto de lisímetros de nível de lençol freático constantes a $37 \mathrm{~cm}$ de profundidade, sendo que a evapotranspiração de referência (ETo) foi definida com grama (Paspalum notatum Flügge). Os autores estabeleceram Kc semanais após o plantio, que variaram de 0,68 a 1,96, e comentaram que os valores foram altos, devido à ETo ter sido relacionada com grama, e não com equações empíricas, como normalmente é feito. Entretanto convém salientar que o espaçamento utilizado pela cultura foi de $1,0 \mathrm{~m}$ X 1,5m, superior aos recomendados por Filgueira (2000) para a cultura. Isso expõe mais o solo, fazendo com que o processo de evaporação seja maior que nas condições do espaçamento recomendado, elevando os valores de evapotranspiração de cultivo (ETc),

\footnotetext{
${ }^{1}$ SERRANO, Z. cultivo de hortalizas en invemadeiro. Ed. Aedos. Barcelona, 1979
} 
conseqüentemente os valores de Kc obtidos. Esse motivo, talvez, expresse mais o ocorrido que a hipótese levantada pelos autores.

Não se encontrou outro trabalho na literatura sobre $\mathrm{Kc}$ em abobrinha. Entretanto, para abóbora, pepino e melão, plantas da mesma família, os valores de Kc variam de 0,7 a 1,0; 0,9 a 1,0; 0,5 a 1,2, respectivamente (Doorenbos \& Pruitt, 1997). Hartz (1996) ressalta que as variações na densidade de plantio, no tipo de condução do experimento e no cálculo da ETo podem gerar erros nos valores de Kc. É conveniente ressaltar-se que o cálculo de ETo, por equações empíricas ou pelo tanque Classe A, nem sempre reflete a evapotranspiração real da cultura na condição climática estudada, exigindo adaptações.

Nota-se que uma adubação adequada é fundamental para a obtenção de bons rendimentos, podendo-se fazer ajustes nos valores recomendados de adubo, de acordo com a produção que se quer atingir e com o estado nutricional da cultura, o que normalmente é feito pela diagnose foliar.

Trani \& Raij (1996) recomendam que, para se obter maior eficiência na diagnose foliar, é importante seguir as instruções de coleta de folhas da melhor maneira possível; ressaltam também que os teores de nutrientes nas folhas diferem, dependendo da época de amostragem, da posição e de diferenças nas cultivares. Trabalhos sobre avaliação do estado nutricional e do material exportado por colheita pela cultura da abobrinha são escassos.

Mills \& Jones Junior (1996) apresentam uma tabela com valores médios de nutrientes em folhas de abobrinha, baseada em amostragem de folhas totalmente expandidas e colhidas antes da produção. Os teores são os seguintes: 40 a $60 \mathrm{~g} \mathrm{~kg}^{-1}$ para $\mathrm{N} ; 3$ a $5 \mathrm{~g} \mathrm{~kg}^{-1}$ para $\mathrm{P} ; 30$ a $50 \mathrm{~g} \mathrm{~kg}^{-1}$ para $\mathrm{K} ; 12$ a $25 \mathrm{~g} \mathrm{~kg}^{-1}$ para Ca; 3 a $10 \mathrm{~g} \mathrm{~kg}^{-1}$ para $\mathrm{Mg} ; 50$ a $200 \mathrm{mg} \mathrm{kg}^{-1}$ para Fe; 50 a $250 \mathrm{mg} \mathrm{kg}^{-1}$ para Mn; 25 a $75 \mathrm{~m} \mathrm{~g} \mathrm{~kg}^{-1}$ para B; 10 a $25 \mathrm{~m} \mathrm{~g} \mathrm{~kg}^{-1}$ para $\mathrm{Cu}$ e 20 a $200 \mathrm{~m} \mathrm{~g} \mathrm{~kg}^{-1}$ para $\mathrm{Zn}$.

A média da concentração de macronutrientes em frutos de abobrinha foi de 28,6 $\mathrm{g} \mathrm{kg}^{-1}$ de $\mathrm{N} ; 7,89 \mathrm{~g} \mathrm{~kg}^{-1}$ de P; 45,2 $\mathrm{g} \mathrm{kg}^{-1}$ de $\mathrm{K} ; 3,8 \mathrm{~g} \mathrm{~kg}^{-1}$ de Ca ; 4,1 $\mathrm{g} \mathrm{kg}^{-1}$ de $\mathrm{Mg}$ e $1,77 \mathrm{~g} \mathrm{~kg}^{-1}$ de $\mathrm{S}$, enquanto de micronutrientes foi $22 \mathrm{mg} \mathrm{kg}$ de B; 13,5 mg $\mathrm{kg}$ de $\mathrm{Cu} ; 100$ mg kg de Fe; 45 mg kg de Mn; 58 mg kg de Zn (Furlani et al., 1978). 
Knott $^{2}$ (1966), citado por Fontes \& Lima (1993), indicou que, para uma produtividade de $19 \mathrm{t} \mathrm{ha}^{-1}$, houve um consumo de nutrientes de $83 \mathrm{~kg} \mathrm{ha}^{-1}$ de $\mathrm{N} ; 7 \mathrm{~kg} \mathrm{ha}^{-1}$ de P; $94 \mathrm{~kg} \mathrm{ha}^{-1}$ de K; $13 \mathrm{~kg} \mathrm{ha}^{-1}$ de Ca e $16 \mathrm{~kg} \mathrm{ha}^{-1}$ de Mg.

Especificamente para a abobrinha, não foram encontrados trabalhos relatando a marcha de absorção de nutrientes ao longo do ciclo vital, o que poderia auxiliar no manejo da fertirrigação. Entretanto Cardoso (1998) preconiza a utilização de adubo com cálcio, principalmente para os frutos novos, recomendando o uso de $10 \mathrm{~g}$ de nitrato de cálcio por planta a cada 10 a 15 dias, iniciando-se uma semana após o transplante.

Hartz \& Hochmuth (1996) trazem em seu trabalho sobre manejo da fertilidade de vegetais irrigados por sistema localizado, um calendário de fertirrigação para abobrinha, onde sugerem taxas de injeção de 1,1 a 2,2 $\mathrm{kg} \mathrm{ha}^{-1} \mathrm{dia}^{-1}$ de $\mathrm{N}$ e de 0,9 a $1,8 \mathrm{~kg} \mathrm{ha}^{-1} \mathrm{dia}^{-1}$ de $\mathrm{K}$, sendo ela dependente da temperatura, que vai influenciar no desenvolvimento da cultura. Porém o total de nutrientes utilizado é independente das condições climáticas. Os autores comentam que, para alguns grupos, como o das cucurbitaceas, a extrapolação de um programa de fertirrigação de uma cultura para outra é possível.

Os valores apresentados na literatura, referentes à extração de nutrientes por planta, são variáveis, devido, principalmente, às condições experimentais em que foram obtidos. Assim, a marcha de absorção, expressa através de curvas de absorção de nutrientes em função da idade da planta, é desejável para o conhecimento da época em que elas absorvem os nutrientes em maiores proporções, tornando possível conhecer-se a época mais propícia para a adubação (Fontes \& Lima, 1993). Segundo Malavolta (1976), existem três maneiras principais de se estudar a marcha de absorção, sendo a mais freqüente a colheita no campo da planta inteira em épocas determinadas, e depois o cálculo das quantidades de nutrientes presentes na planta.

\footnotetext{
${ }^{2}$ KNOTT,J. E. Hnadbook for vegetable growers. New York: Jonh Willey \& Sons. 1996
} 


\section{MATERIAL E MÉTODOS}

\subsection{Caracterização da área experimental}

Dois experimentos foram conduzidos, um no período de 23 maio a 2 de agosto, e outro de 19 de setembro a 5 de dezembro de 2000 na fazenda Areão, pertencente à Escola Superior de Agricultura "Luiz de Queiroz" (ESALQ) da Universidade de São Paulo (USP) em Piracicaba, SP, cujas coordenadas geográficas de referência são: latitude $22^{\circ} 42^{\prime} 30^{\prime \prime} \mathrm{S}$, longitude $47^{\circ} 38^{\prime} \mathrm{W}$ e altitude de $580 \mathrm{~m}$.

O clima da região, segundo a classificação de Köppen, é do tipo Cwa, mesotérmico, subtropical úmido, com estiagem no inverno. A precipitação média anual é de $1250 \mathrm{~mm}$, sendo concentrada, predominantemente, de novembro a fevereiro. A temperatura média do ar é $20,8^{\circ} \mathrm{C}$, com mínima em torno de $10^{\circ} \mathrm{C}$ (julho) e máxima em torno de $30^{\circ} \mathrm{C}$ (janeiro). A umidade relativa média do ar é 69\% (Ometto, 1989).

O solo da área experimental é classificado como Terra Roxa Estruturada (Alfisol) série Luiz de Queiroz, com declividade média de 2\%. A análise química e física do solo foram feitas para as profundidades de $0-20 \mathrm{~cm}$ e $20-40 \mathrm{~cm}$ (Tabela 1). Com base na análise do solo, e seguindo-se recomendação de adubação sugerida por Trani \& Raij (1996), aplicourse o calcáreo dolomítico, com a seguinte composição: 39\% de $\mathrm{CaO}$ e $13 \%$ de $\mathrm{MgO}$ e PRNT 91\%, na quantidade de 3,0 $\mathrm{t} \mathrm{ha}^{-1}$, cinco meses antes do plantio. Decorrido esse período, uma nova análise do solo foi feita nas mesmas profundidades anteriores (Tabela 2). A massa específica do solo na área experimental foi de $1225 \mathrm{~kg} \mathrm{~m}^{-3}$ na camada de $0-10 \mathrm{~cm}, 1397 \mathrm{~kg} \mathrm{~m}^{-3}$ na camada de $10-20 \mathrm{~cm}$ e de $1368 \mathrm{~kg} \mathrm{~m}^{-3}$ na camada de $20-30 \mathrm{~cm}$. 
Tabela 1. Análise química e física do solo da área antes da instalação do primeiro experimento. Piracicaba, SP. 1999.

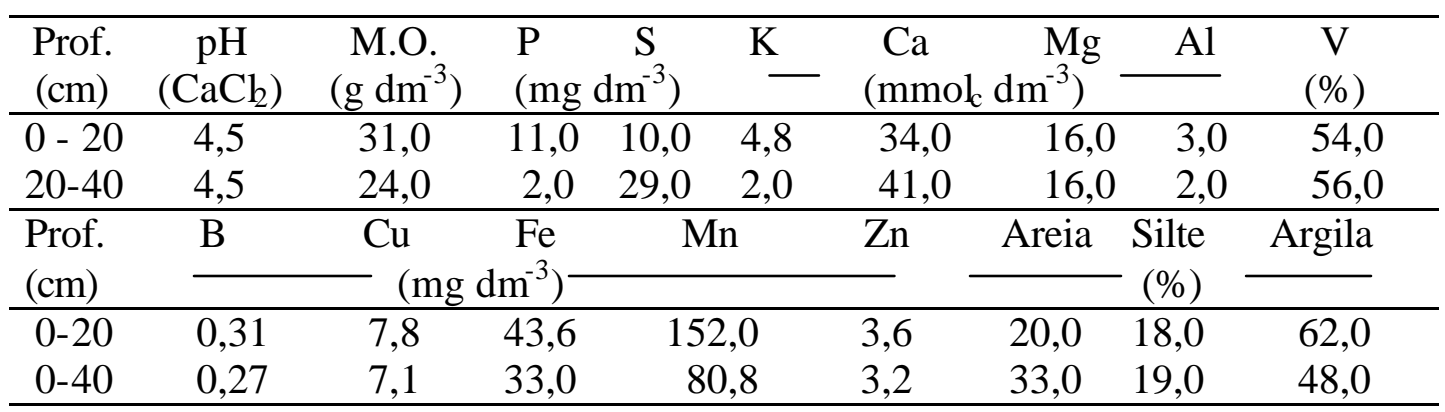

Tabela 2 . Análise química e física do solo da área experimental após a correção do solo. Piracicaba, SP. 2000.

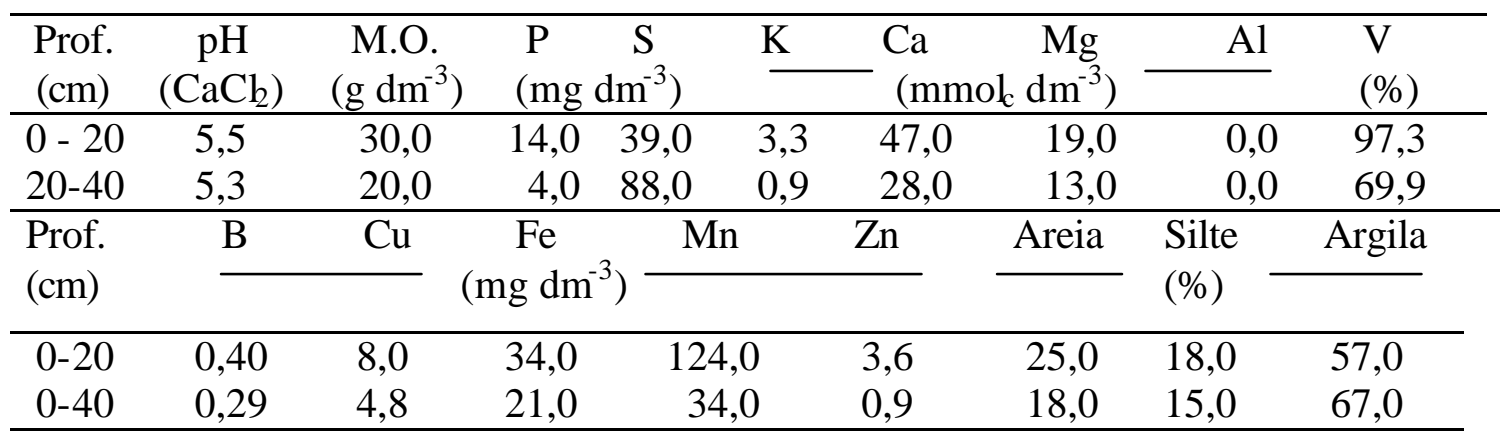

A água utilizada para irrigação foi proveniente do próprio sistema de bombeamento de água potável da cidade de Piracicaba. Na Estação de Tratamento de Água (ETA), é feita uma análise diária de pH, condutividade elétrica (CE), dureza, sólidos totais e elementos químicos, cujas médias dos valores mensais se encontram na Tabela 3.

Os teores de Mn e Fe na água, possíveis causadores de entupimento nos


respectivamente; acima deles poder-se-ia gerar algum grau de entupimento (Ayers \& Westcost, 1991). As outras características não mostraram limitação ao uso da água para irrigação durante o período experimental. 
Tabela 3 . Análise química da água utilizada na irrigação. 2000. Piracicaba, SP. *

\begin{tabular}{lccccc}
\hline Características & Unidade & \multicolumn{4}{c}{ Resultados nos meses de } \\
\cline { 3 - 6 } & & 0,00 & 0,00 & 0,01 & 0,00 \\
\cline { 3 - 6 } Manganês & $\left(\mathrm{mg} \mathrm{L}^{-1}\right)$ & 0,02 & 0,03 & 0,03 & 0,03 \\
Ferro total & $\left(\mathrm{mg} \mathrm{L}^{-1}\right)$ & 31,0 & 23,0 & 38,0 & 54,0 \\
Cloreto & $\left(\mathrm{mg} \mathrm{L}^{-1}\right)$ & 45,0 & 58,0 & 93,0 & 105,0 \\
Dureza total & $\left(\mathrm{mg} \mathrm{L}^{-1} \mathrm{de} \mathrm{CaCO}_{3}\right)$ & 8,2 & 8,0 & 7,8 & 7,8 \\
pH & & 0,17 & 0,19 & 0,23 & 0,26 \\
CE & $\left(\mathrm{dS} \mathrm{m}^{-1}\right)$ & 174,0 & 181,0 & 215,0 & 215,0 \\
Sólidos totais & $\left(\mathrm{mg} \mathrm{L}^{-1}\right)$ & &
\end{tabular}

* FONTE: SEMAE/ETA - Capim Fino. Piracicaba (SP).

\subsection{Expe rimento I}

\subsubsection{Implantação e manejo da cultura}

A abobrinha (Cucurbita pepo L.), tipo caserta, CAC melhorada, foi semeada em 10 de maio em bandejas de isopor. Após dois dias da germinação, as mudas foram pré-imunizadas com uma estirpe fraca do vírus PRSV-W (Papaya ringspot virus type $W$ ) e transplantadas para o local definitivo no espaçamento de 1,0 m entre linhas e 1,0 m entre plantas, quatro dias após a imunização, em 23 de maio.

Seguindo-se a recomendação de adubação sugerida por Trani \& Raij (1996), foram aplicados $40 \mathrm{~kg} \mathrm{ha}^{-1} \mathrm{de} \mathrm{N}, 400 \mathrm{~kg} \mathrm{ha}^{-1}$ de $\mathrm{P}_{2} \mathrm{O}_{5}, 100 \mathrm{de} \mathrm{kg} \mathrm{ha}^{-1} \mathrm{~K}_{2} \mathrm{O}$, aplicados na forma de uréia, superfosfato simples e cloreto de potássio, respecitvamente. Também foram utilizados $2 \mathrm{~kg}$ de esterco curtido de gado na cova de plantio, uma semana antes do transplante. A adubação indicada para cobertura, de 100 a $150 \mathrm{~kg} \mathrm{ha}^{-1}$ de $\mathrm{N}$ e 60 a $120 \mathrm{~kg} \mathrm{ha}^{-1}$ de $\mathrm{K}_{2} \mathrm{O}$, foi feita via água de irrigação, tendo sido utilizados uréia e nitrato de cálcio como fontes de $\mathrm{N}$ e cloreto de potássio como fonte de $\mathrm{K}$.

O método da pressão diferencial, com um tanque de derivação de fluxo, foi empregado para a injeção do fertilizante na água de irrigação. A calibração do tanque, com capacidade para 75 litros, ocorreu conforme a recomendação da FAO, simplificada por Shani (1981), que consistiu em passar pelo tanque de fertilizantes uma quantidade de solução igual ou superior a quatro vezes o seu volume, sendo regulado 
para se ter um tempo de aplicação de 20 minutos. A uréia e o nitrato de potássio foram utilizados como adubos aplicados a cada dois dias, a partir do 14ํㅜ dia após o transplante (DAT), com término aos 52 DAT. O parcelamento dos fertilizantes foi de $20 \%, 35 \%$, $30 \%$ e $15 \%$ da quantidade total, baseado no programa de fertirrigação para abobrinha proposto por Hartz \& Hochmuth (1996). O adubo correspondente a cada percentual foi distribuído em cinco aplicações consecutivas. Posteriormente, no dia 6 de julho (44 DAT), fertirrigoutse com nitrato de cálcio, pois começaram a surgir sintomas de "fundo preto" nos frutos, tendo sido feitas cinco aplicações.

O controle fitossanitário foi feito por meio de pulverizações, utilizandose, principalmente, Deltamethrin, Malathion, Fenthion, Imidacloprid e Thiovit e capinas manuais, sempre que se fizeram necessárias.

\subsubsection{Manejo da irrigação e aplicação de $\mathrm{CO}_{2}$}

A água foi aplicada a partir de três caixas, com capacidade para $1.000 \mathrm{~L}$ cada, conectadas entre si e reguladas por um bóia, de forma que a capacidade armazenada total era de 3.000 L. Uma das caixas era ligada à motobomba, com vazão máxima de $2,4 \mathrm{~m}^{3} \mathrm{~h}^{-1}$, altura manométrica de $900 \mathrm{kPa}$, potência de $1 \mathrm{HP}$ e rotação de $3450 \mathrm{rpm}$.

Conectada à motobomba, foi instalada uma tubulação de PVC rígido de 20mm e a esta um hidrômetro, para se ter uma melhor determinação do volume de água aplicado. Um desvio foi feito na tubulação, de modo a permitir a injeção de fertilizantes no sistema, por meio de um tanque de derivação. A água provinda desse sistema foi subdividida em quatro saídas, onde ocorria a injeção de $\mathrm{CO}_{2}$, de acordo com cada tratamento (Figura 1 ).

A água era conduzida até as parcelas através de tubulações de polietileno flexível preto de $20 \mathrm{~mm}$ de diâmetro. Na entrada de cada parcela, foi instalado um regulador de pressão, de modo a assegurar ao sistema uma uniformidade de pressão. $\mathrm{O}$ regulador estava conectado a uma tubulação de PVC rígido de $32 \mathrm{~mm}$ de diâmetro, perfurada lateralmente a cada metro, onde era colocado um anel de borracha de vedação 
e a ele conectada a fita com os tubogotejadores queengill. Estes foram instalados na superfície do solo, possuindo as seguintes características: 16,5mm de diâmetro interno, espessura da parede de $0,25 \mathrm{~mm}$, pressão de serviço recomendada entre $50 \mathrm{kPa}$ e $70 \mathrm{kPa}$, vazão nominal de $4,0 \mathrm{~L} \mathrm{~h}^{-1} \mathrm{~m}^{-1}$ ou $0,44 \mathrm{~L} \mathrm{~h}^{-1}$ por emissor.

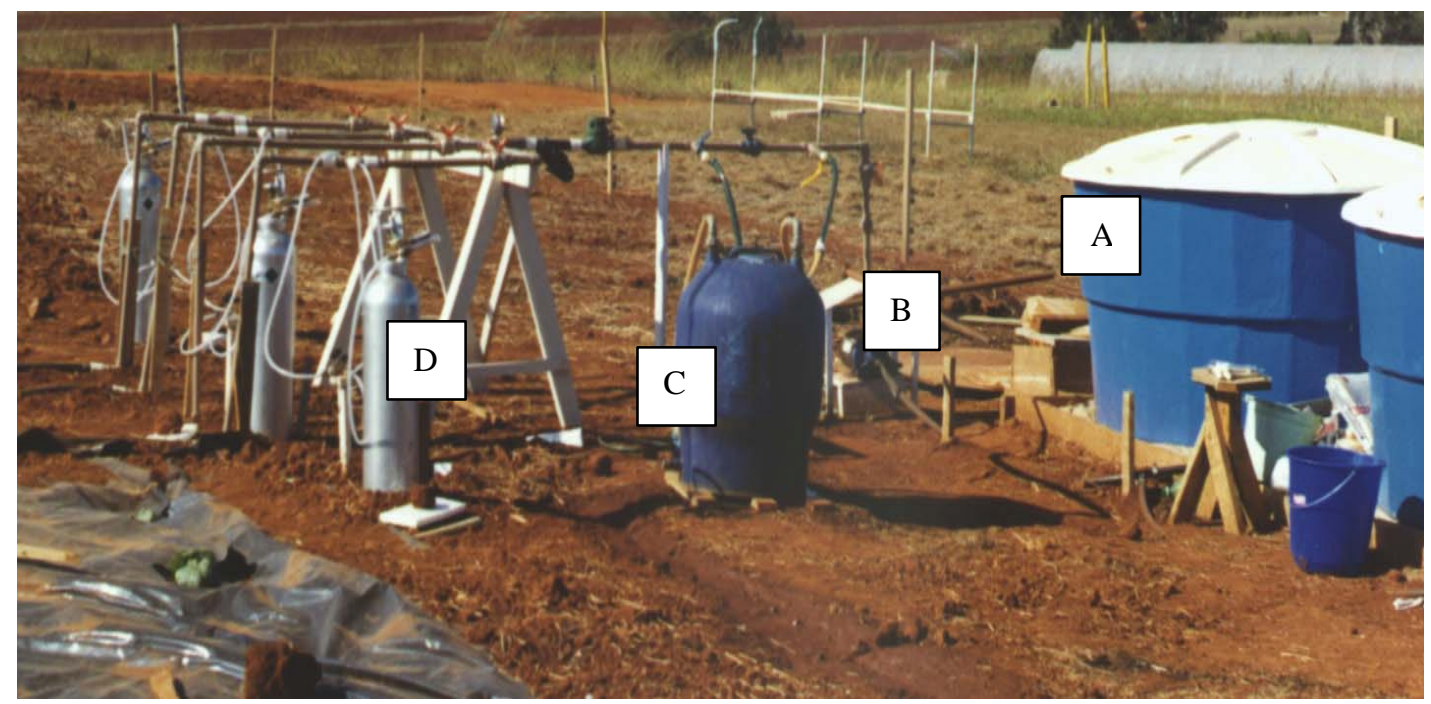

Figura 1- Cabeçal de controle mostrando a caixa d'água (A), a motobomba (B), o tanque de derivação (C) e os cilindros contendo o dióxido de carbono (D).

Para o manejo da irrigação, a água foi reposta diariamente ao solo, estimada com base na leitura do tanque evaporimétrico do tipo Classe A, instalado próximo ao local do experimento, conforme a Equação 5:

$$
\mathrm{ETcg}=\mathrm{Kc} \cdot \mathrm{Kp} \cdot \mathrm{Kr} \cdot \mathrm{ECA}
$$

em que:

ETcg - evapotranspiração da cultura sob irrigação localizada, $\mathrm{mm} \mathrm{dia}^{-1}$;

Kc - coeficiente da cultura , em função do estádio fenológico, adimensional ; 
Kp - coeficiente do tanque, adimensional $(0,72)^{3}$;

$\mathrm{Kr}$ - fator de redução, admensional e

ECA - evaporação do tanque classe A, mm.

Adotaram-se, como coeficiente de cultura $(\mathrm{Kc})$ até aos $35 \mathrm{DAT}$, os valores citados por Klosowski et al. (1999) para abobrinha: 0,68 a 0,82 nesses 35 dias; para o ciclo total, o Kc varia de 0,68 a 1,96. Posteriormente, optourse por um Kc baseado em Doorenbos \& Pruitt (1997) para a cultura da abóbora, de 0,7 para todo o ciclo, exceto para o período entre 45 e 68 DAT, de 0,9 .

O fator de redução (Kr) foi calculado pela Equação 6, citada por Keller \& Bliesner (1990).

$$
\mathrm{Kr}=0,1 .(\mathrm{GC})^{0,5}
$$

em que:

$\mathrm{Kr}$ - Fator de redução, adimensional e no máximo igual a 1;

GC - Taxa de projeção da copa.

Dez plantas foram escolhidas aleatoriamente a cada semana, para o cálculo de GC. A Tabela 4 indica os valores de GC observados, os fatores de redução (Kr) calculados pela equação (6) e o período em que eles foram adotados. A irrigação foi baseada no tanque classe A, sendo a umidade do solo monitorada por seis baterias de tensiômetros, metade delas instaladas em subparcelas com cobertura plástica e as outras, em subparcelas com o solo nu. Os tensiômetros foram posicionados a $10 \mathrm{~cm}$ de profundidade e foram lidos diariamente antes das irrigações. Procuroutse irrigar a cultura, de modo a manter-se o solo sempre próximo de tensões entre $6 \mathrm{kPa}$ e $10 \mathrm{kPa}$, a $10 \mathrm{~cm}$ de profundidade. Uma metodologia semelhante foi utilizada por Bhella \& Kwolek (1984), para o manejo da irrigação localizada, com o uso de mulch em abobrinha.

\footnotetext{
${ }^{3}$ SENTEHAS, P.C.; COELHO FILHO, M.A.; VILLA NOVA, N.A. et. al. Coeficiente do tanque Classe A (Kp) para a estimativa diária da evapotranspiração de referência. In: Cong. Bras. de Agro., 11,Florianópolis. CD-ROM. 1999.
} 
O tempo de irrigação foi calculado pela expressão:

$$
\mathrm{Ti}=\underline{60} \cdot \underline{\mathrm{ETcg}} \cdot \mathrm{Dg} \cdot \mathrm{Dl}
$$

(Ef . qg)

em que :

Ti - tempo de irrigação, min;

ETcg - evapotranspiração calculada pela equação 1, mm;

Dg - distância entre os gotejadores , 0,11m;

Dl - distância entre as linhas de gotejadores , 1,0 m;

Ef - eficiência do sistema de irrigação, considerada de $95 \%$ e

qg - $\quad$ vazão do gotejador, $0,44 \mathrm{~L} \mathrm{~h}^{-1}$.

Tabela 4. Valores da taxa de projeção da copa (GC) observados em 10 plantas, fator de redução $(\mathrm{Kr})$ de evapotranspiração da abobrinha e os períodos em que foram adotados. Piracicaba-SP.2000.

\begin{tabular}{ccc}
\hline GC (\%) & Kr & Período de adoção \\
\hline 10 & 0,3 & 23 de maio a 15 de junho \\
20 & 0,4 & 16 a 27 de junho \\
50 & 0,7 & 28 de junho a 14 de julho \\
100 & 1,0 & 15 de julho ao final do experimento \\
\hline
\end{tabular}

$\mathrm{O}$ sistema de aplicação de $\mathrm{CO}_{2}$ foi composto por três cilindros, um para cada tratamento. Havia uma válvula junto ao cilindro, um fluxômetro para quantificar a dose de $\mathrm{CO}_{2}$ a ser injetada e um injetor do tipo venturi, ligado à tubulação de água, que introduzia o gás na água de irrigação.

A aplicação de água carbonatada teve início aos 6 DAT e findou aos 66 DAT. Para a quantificação do total de dióxido de carbono aplicado, cada tratamento possuía seu próprio cilindro, que foi pesado no início e no final de cada experimento. A diferença de peso resultou no total de gás aplicado, posteriormente transformado para $\mathrm{kg} \mathrm{ha}^{-1}$. O tempo de aplicação do gás variou em função da lâmina de irrigação, tendo 
início quando ocorria a pressurização do sistema de irrigação, e término, com o fim da aplicação da lâmina de água.

O enriquecimento de dióxido de carbono no ambiente foi monitorado pelo analisador de $\mathrm{CO}_{2}$ LI-800 (LI-COR, Lincoln, Nebraska.), buscando-se verificar se a quantidade de $\mathrm{CO}_{2}$ do ambiente era modificada, e por quanto tempo esse $\mathrm{CO}_{2}$ ficava efetivamente disponível à cultura.

Para a utilização do aparelho analisador de $\mathrm{CO}_{2}$, foi necessária a instalação de uma bomba de sucção, inserida num tubo fechado de PVC de 0,1m de diâmetro, que captava ar somente por uma mangueira de $0,01 \mathrm{~m}$, junto à copa da cultura e o mandava para o interior do analisador de $\mathrm{CO}_{2}$, alimentado por uma bateria de 12 Volts. O analisador quantificava o nível de gás carbônico presente na tubulação e emitia um sinal analógico, transformado, em seguida, na forma digital, pelo multímetro. $\mathrm{O}$ aparelho foi previamente calibrado com uma concentração de $\mathrm{CO}_{2}$ conhecida antes das medidas. As medidas foram efetuadas a $15 \mathrm{~cm}$ de altura, em relação à superfície, e dentro da copa de uma planta, no centro da parcela (Figura 2). As leituras foram feitas antes de acionado o sistema de irrigação, durante a irrigação e após 5, 20 e 40 minutos do término da irrigação, em todos os tratamentos. Cada tratamento possuía uma mangueira que permanecia por 2 minutos ligada ao aparelho. Decorrido esse tempo, três leituras eram feitas, com intervalos de 10 segundos, e contabilizadas as suas médias, passando-se a fazer a leitura em outro tratamento.

Semanalmente, cerca de $300 \mathrm{ml}$ da água de irrigação eram coletados na fonte e diretamente nos gotejadores, para a análise de seu $\mathrm{pH}$ e da sua condutividade elétrica (CE), em dS m ${ }^{-1}$. 

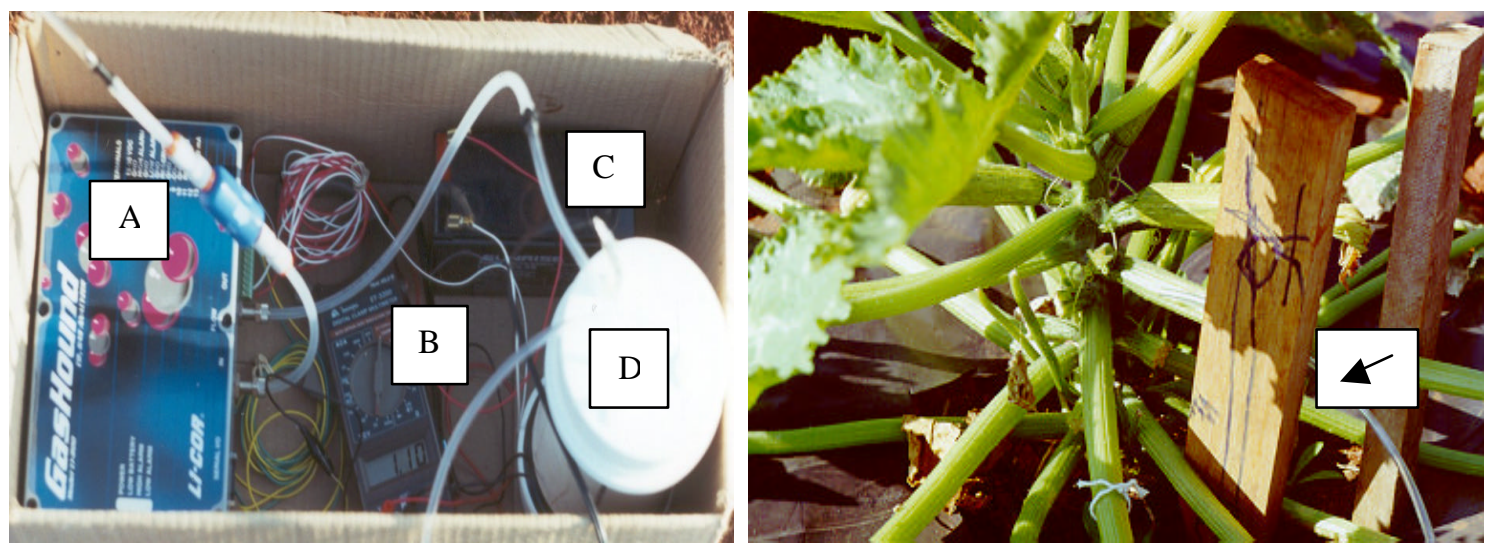

Figura 2 - Analisador de $\mathrm{CO}_{2}$ LI-800 (A), multímetro (B), bateria de 12 Volts (C) e recipiente de PVC contendo a bomba de sucção (D) e a mangueira que captava o ar junto à planta a cerca de $15 \mathrm{~cm}$ do solo.

A temperatura do solo foi monitorada de duas formas: por meio de geotermômetros, colocados a $10 \mathrm{~cm}$ de profundidade em todas as subparcelas, e com termômetro de máxima e mínima nas subparcelas com mulch e sem mulch sobre o solo, como termômetro de relva $a^{4}$ Esse termômetro foi protegido com isopor, para evitar a radiação direta sobre ele. O objetivo dessa determinação foi observar um possível efeito da temperatura sobre a cultura e o solo. As leituras dos geotermômetros e dos termômetros de relva foram feitas uma vez por dia, às 10:00, pouco antes do início das irrigações.

Foi colocado um extrator de solução do solo, de cápsula porosa, a $15 \mathrm{~cm}$ de profundidade em cada subparcela. Para facilitar o movimento de solução para os extratores, era aplicado um vácuo, com o uso de uma seringa, numa tensão em torno de $70 \mathrm{kPa}$. Semanalmente, o conteúdo dessa solução do solo era retirado de cada extrator e eram feitas as leituras de seu $\mathrm{pH}$ e da CE. Ao final do experimento, uma mesma quantidade de solução foi retirada dos tratamentos e analisada quimicamente.

\footnotetext{
${ }^{4}$ Termômetro de relva trata-se de um termômetro de mínima que é colocado sobre o solo gramado, objetivando conhecer-se a intensidade de geada.(Tubelis,A. \& Nascimento,F.J.L. Meteorologia Descritiva. p. 193.1992)
} 


\subsubsection{Metodologia estatística}

O modelo matemático para a análise da variância (ANOVA) das variáveis estudadas foi o delineamento em blocos ao acaso, com parcelas subdivididas (split plot), com três repetições. As parcelas constaram das doses de $\mathrm{CO}_{2}$ e as subparcelas, das coberturas de solo; com e sem uso da cobertura plástica de polietileno com 150 micras sobre o solo (mulch).

Cada subparcela teve 5,0 $\mathrm{m}$ de largura e 5,0 $\mathrm{m}$ de comprimento, com cinco fileiras de plantas espaçadas 1,0 m entre si. Os canteiros contavam com 25 plantas, sendo 9 consideradas como área útil.

A expressão matemática que descreve o delineamento é a seguinte:

$$
\mathrm{y}_{\mathrm{ijk}}=\mathrm{m}+\mathrm{D}_{\mathrm{i}}+\mathrm{B}_{\mathrm{j}}+\mathrm{e}_{\mathrm{ij}}+\mathrm{C}_{\mathrm{k}}+(\mathrm{DC})_{\mathrm{ik}}+\varepsilon_{\mathrm{ijk}}
$$

onde:

$\mathrm{y}_{\mathrm{ijk}} \quad$ - valor observado referente à iésima dose de $\mathrm{CO}_{2}$, no j-ésimo bloco, na k-ésima cobertura;

m - fator fixo, estimado pela média geral;

$\mathrm{D}_{\mathrm{i}} \quad$ - efeito da i-ésima dose de $\mathrm{CO}_{2}, \mathrm{i}=1,2,3,4$;

$B_{j} \quad$ - efeito do j-ésimo bloco, $\mathrm{j}=1,2,3$;

$\mathrm{e}_{\mathrm{ij}} \quad$ - erro aleatório correspondente às parcelas (variação do acaso sobre as observações da iésima dose de $\mathrm{CO}_{2}$ no j-ésimo bloco);

$\mathrm{C}_{\mathrm{k}} \quad$ - efeito da k-ésima cobertura, $\mathrm{k}=1,2$;

$(\mathrm{DC})_{\mathrm{ik}}$ - efeito da interação da i-ésima dose de $\mathrm{CO}_{2}$ com a k-ésima cobertura;

$\varepsilon_{\mathrm{ijk}} \quad$ - erro aleatório correspondente às subparcelas (variação do acaso sobre as observações da iésima dose de $\mathrm{CO}_{2}$, k-ésima cobertura, no j-ésimo bloco).

$\mathrm{Na}$ parcela, para a definiçãa das doses de $\mathrm{CO}_{2}$, o primeiro procedimento foi calcular-se a vazão média do sistema de irrigação, que foi de $0,15 \mathrm{~L} \mathrm{~s}^{-1}$. Com base 
em informações prévias de como aumentar a concentração de $\mathrm{CO}_{2}$ na água sem, no entanto, saturá-la com o gás, procurou-se injetar $\mathrm{CO}_{2}$ na tubulação, nas dosagens de $22,7 \mathrm{~mL} \mathrm{~s}^{-1}, 45,5 \mathrm{~mL} \mathrm{~s}^{-1}$ e $68,3 \mathrm{~mL} \mathrm{~s}^{-1}$. Para isso, contoutse com o auxílio do fluxímetro que regulou a vazão de gás a ser injetado na tubulação. Posteriormente, uma aferição foi feita, utilizando-se uma proveta graduada de $200 \mathrm{ml}$, que era imersa em água, aonde o gás, proveniente do cilindro de $\mathrm{CO}_{2}$ com pressão de $300 \mathrm{kPa}$, era desviado por uma mangueira. Por fim, o tempo para preenchimento total da proveta com o gás era cronometrado. No final do experimento, com a pesagem dos cilindros de $\mathrm{CO}_{2}$, foi feita uma conversão do total aplicado para $\mathrm{kg} \mathrm{ha}^{-1}$.

A subparcela caracterizourse pela cobertura, ou não, do solo com plástico de polietileno preto, com 150 micra de espessura, sendo representada pela letra "M".

Os tratamentos apresentaram as seguintes descrições:

0 - tratamento sem cobertura, sem adição de $\mathrm{CO}_{2}$;

$0 \mathrm{M}$ - tratamento com cobertura e sem a adição de $\mathrm{CO}_{2}$;

300 - tratamento sem cobertura com uso de $59 \mathrm{~kg} \mathrm{ha}^{-1}$ de $\mathrm{CO}_{2}$;

$300 \mathrm{M}$ - tratamento com cobertura e com uso de $59 \mathrm{~kg} \mathrm{ha}^{-1} \mathrm{de}_{\mathrm{CO}_{2}}$;

600 - tratamento sem cobertura e com uso de $148 \mathrm{~kg} \mathrm{ha}^{-1} \mathrm{de}_{\mathrm{CO}_{2}}$;

$600 \mathrm{M}$ - tratamento com cobertura e com uso de $148 \mathrm{~kg} \mathrm{ha}^{-1}$ de $\mathrm{CO}_{2}$;

900 - tratamento sem cobertura e com uso de $274 \mathrm{~kg} \mathrm{ha}^{-1} \mathrm{de}^{\mathrm{CO}_{2}}$;

$900 \mathrm{M}$ - tratamento com cobertura e com uso de $274 \mathrm{~kg} \mathrm{ha}^{-1}$ de $\mathrm{CO}_{2}$;

O esquema de análise de variância das variáveis estudadas e a distribuição dos tratamentos no campo são apresentados na Tabela 5 e na Figura 3, respectivamente. 
Tabela 5 . Esquema de análise de variância e o teste F para as variáveis analisadas

\begin{tabular}{|c|c|c|c|c|}
\hline $\begin{array}{l}\text { Causas de } \\
\text { Variação }\end{array}$ & $\begin{array}{c}\text { G.L } \\
.\end{array}$ & S.Q. & Q.M. & $\mathrm{F}^{*}$ \\
\hline Blocos & 2 & SQ Blocos & QM Blocos & \\
\hline Doses de $\mathrm{CO}_{2}$ & 3 & SQ Doses & QM Doses & $\begin{array}{c}\text { QM Doses/QM } \\
\operatorname{Res}(\mathrm{A})\end{array}$ \\
\hline Resíduo (A) & 6 & SQ Res. (A) & QM Res. (A) & - \\
\hline (Parcelas) & (11) & SQ Parcelas & - & - \\
\hline Cobertura & 1 & SQ Cobert. & QM Cobert. & $\begin{array}{c}\text { QM Cobert./QM } \\
\operatorname{Res}(\mathrm{B})\end{array}$ \\
\hline Doses*Cobertura & 3 & SQ da interação & QM da interação & $\begin{array}{c}\text { QM da interação/ } \\
\text { QMRes(B) }\end{array}$ \\
\hline Resíduo (B) & 8 & SQ Res. (B) & QM Res. (B) & - \\
\hline Total & 23 & SQ Total & - & - \\
\hline
\end{tabular}

* Os efeitos dos blocos e dos tratamentos foram testados até $10 \%$ de probabilidade.

Dado o fator Cobertura (utilização ou não de mulch) ser qualitativo, sempre que o teste $\mathrm{F}$ detectou diferença significativa entre suas médias ou entre as médias da interação (dentro de cada dose), o detalhamento da análise foi feito através do próprio teste $\mathrm{F}$, já que se trata de apenas duas coberturas, considerando, também, um nível mínimo de significância de $10 \%$ ( $\mathrm{p} \leq 0,10)$. Já para o fator Doses e suas interações (doses dentro de cada cobertura), como se trata de fator quantitativo, foi feito um detalhamento da análise da variância por meio do estudo do comportamento da variável, em função das doses de $\mathrm{CO}_{2}$, utilizando-se a análise de regressão e o ajuste de curvas que tenham um significado biológico. O modelo foi escolhido, com base no maior valor do coeficiente de determinação $\left(\mathrm{R}^{2}\right)$ e na significância estatística dos coeficientes pelo teste t. Para as variáveis que não obtiveram uma distribuição normal, os valores foram transformados para $\log \mathrm{x}$. 


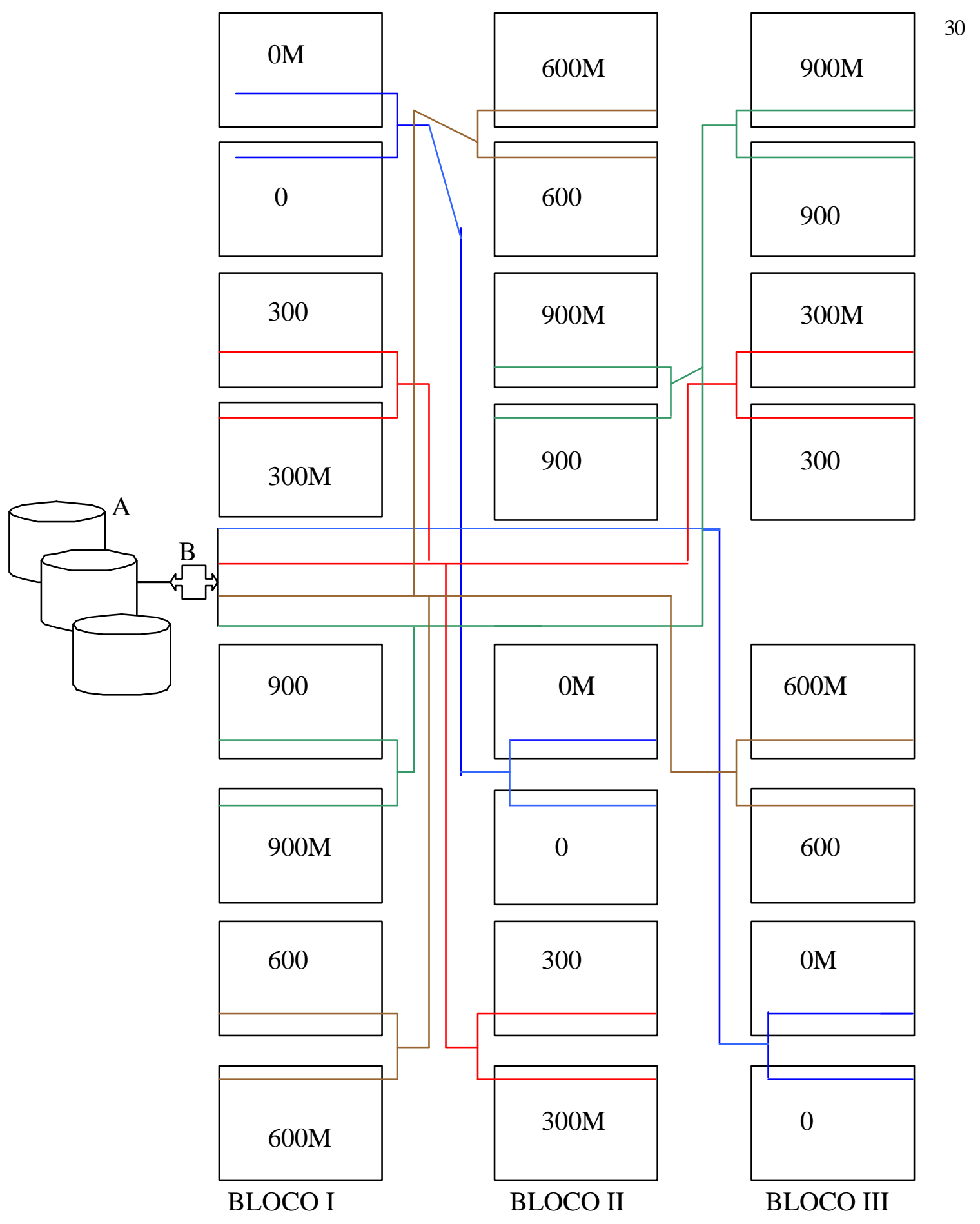

Figura 3- Esquema da área experimental, mostrando os tratamentos (0, 0M, 300, 300M, 600, 600M, 900 e 900M), as caixas de água (A), o cabeçal de controle (B) e a exemplificação da irrigação entre as parcelas. 


\subsubsection{Variáveis analisadas da planta}

\subsubsection{Análise do crescimento}

Durante o trabalho de campo, três plantas de cada tratamento foram escolhidas para a determinação da área foliar, no final do experimento aos 68 DAT. A área foliar foi estimada usando-se o método não destrutivo, proposto por Araújo et al., 2000 .

Posteriormente, ao final do ciclo, essas mesmas plantas foram retiradas e levadas à estufa de circulação forçada entre $65^{\circ} \mathrm{C}$ e $70^{\circ} \mathrm{C}$ por 48 horas, para a obtenção da massa de material seco, tanto da parte aérea quanto da raiz e para o cálculo da razão entre a parte aérea e as raízes.

\subsubsection{Número de frutos e rendimento}

Durante a fase de produção, os frutos foram retirados diariamente no ponto comercial, quantificados e pesados individualmente, em cada colheita. $\mathrm{O}$ rendimento foi estimado em $\mathrm{kg} \mathrm{ha}^{-1}$ para cada tratamento. A colheita prolongou se por 30 dias, após a primeira.

\subsubsection{Análise química de frutos e folhas}

Cerca de 20 folhas foram escolhidas por parcela para a análise química. A folha coletada foi a quarta do ápice para baixo, sendo retirada no início da fase de floração, numa adaptação de Trani \& Raij (1996). Posteriormente, as amostras foram levadas ao laboratório, lavadas e submetidas à secagem em estufa de circulação forçada de ar, com temperatura entre $65{ }^{\circ} \mathrm{C}$ e $70^{\circ} \mathrm{C}$ por 48 horas para a obtenção da massa de material seco. As análises químicas de folhas e de quatro frutos de cada tratamento foram realizadas de acordo com a metodologia proposta por Sarruge \& Haag (1974). 


\subsection{Experimento II}

\subsubsection{Características gerais}

Após o primeiro experimento, subamostras do solo foram retiradas em todas as unidades experimentais e agrupadas segundo cada tratamento, de modo a constituírem uma só amostra. Elas foram analisadas quimicamente e serviram como base para a recomendação de adubação do experimento II, seguindo recomendação de Trani \& Raij (1996) (Tabela 6).

O solo foi previamente preparado e, conforme a recomendação de adubação, foram aplicados, nas linhas de transplante, $40 \mathrm{~kg} \mathrm{ha}^{-1} \mathrm{de} \mathrm{N}, 400 \mathrm{~kg} \mathrm{ha}^{-1} \mathrm{de}$ $\mathrm{P}_{2} \mathrm{O}_{5}, 100$ de $\mathrm{kg} \mathrm{ha}^{-1} \mathrm{~K}_{2} \mathrm{O}$; foram utilizados como adubos a uréia, o superfosfato simples e o cloreto de potássio, respectivamente. Numa adaptação do programa de fertirrigação recomendado por Hartz \& Hochmuth (1996), parte da adubação indicada para a cobertura foi feita via água de irrigação, utilizando-se um tanque de derivação de fluxo com capacidade para 75 litros. Como adubos, foram utilizados a uréia e o nitrato de potássio, aplicados a cada dois dias, a partir do $23^{-}$DAT, no caso, no dia 5 de outubro. O parcelamento das doses foi de $20 \%, 38 \%$ e $42 \%$ da quantidade total, sendo que a aplicação de cada percentual (dose) foi dividida em seis partes iguais. Posteriormente, aos 29 DAT, por ocasião do início da colheita, usourse nitrato de cálcio, em cinco aplicações, buscando-se evitar o surgimento de "fundo preto" nos frutos. No total, foram

aplicados cerca de $91 \mathrm{~kg} \mathrm{ha}^{-1}$ de $\mathrm{N} ; 66 \mathrm{~kg} \mathrm{ha}^{-1}$ de $\mathrm{K}_{2} \mathrm{O}$ e $22 \mathrm{~kg} \mathrm{ha}^{-1}$ de Ca, via fertirrigação. 
Tabela 6 . Análise química do solo da área antes da instalação do segundo experimento. Piracicaba,SP. 2000.



\subsubsection{Implantação e manejo da cultura}

A abobrinha (Cucurbita pepo L.), tipo caserta, híbrido novita, foi semeada em bandejas de isopor em 6 de setembro. Após dois dias da germinação, as mudas foram pré-imunizadas com uma estirpe fraca do vírus PRSV-W (Papaya ringspot virus type $W$ ) e transplantadas no local definitivo no espaçamento de 1,0 m entre linhas e 1,0 m entre plantas, quatro dias após a imunização, no dia 20 de setembro.

O controle fitossanitário e o manejo de irrigação foram feitos de forma semelhante à do primeiro experimento. A aplicação das doses de $\mathrm{CO}_{2}$, via água de irrigação, teve início dia 30 de setembro, 10 DAT, e fim aos 65 DAT. 


\subsubsection{Manejo da irrigação e aplicação de $\mathrm{CO}_{2}$}

Para o manejo da irrigação, a água foi reposta ao solo, estimada com base no tanque evaporimétrico do tipo classe A, e sempre que a tensão do solo indicava $10 \mathrm{kPa}$ pelo tensiômetro instalado a $10 \mathrm{~cm}$ de profundidade.

Para a aplicação do $\mathrm{CO}_{2}$ utilizou-se o mesmo procedimento do primeiro experimento.

Para o cálculo da taxa de projeção da copa (CG), dez plantas foram escolhidas aleatoriamente a cada semana. A Tabela 7 indica os valores de CG medidos, o fator de redução $(\mathrm{Kr})$ calculado pela equação (2) e o período em que eles foram adotados.

Tabela 7. Valores da taxa de projeção da copa (CG) observados em 10 plantas, fator de redução $(\mathrm{Kr})$ de evapotranspiração da abobrinha e período em que foram adotados. Piracicaba-SP.2000

\begin{tabular}{ccc}
\hline CG $(\%)$ & Kr & Período de adoção \\
\hline 10 & 0,3 & 19 a 30 de setembro \\
25 & 0,5 & 1 a 11 de outubro \\
50 & 0,7 & 12 a 20 de outubro \\
100 & 1,0 & 21 de outubro ao final do experimento \\
\hline
\end{tabular}

O Kc foi de 0,7 para todo o ciclo, exceto para o período entre 30 e 40 DAT, quando foi de 0,9, com base nas considerações de Doorenbos \& Pruitt (1997) para a cultura da abóbora.

\subsubsection{Metodologia estatística}

O modelo matemático para a análise de variância (ANOVA) foi o delineamento em blocos ao acaso com parcelas subdivididas (split plot), com três 
repetições. As parcelas constaram das doses de $\mathrm{CO}_{2}$ e as subparcelas, das coberturas de solo (com e sem uso da cobertura plástica de polietileno de cor preta e com 150 micras de espessura, denominado mulch).

Os procedimentos de cálculos, a forma de aplicação e a aferição da injeção do gás foram semelhantes aos do primeiro experimento. Porém as doses de $\mathrm{CO}_{2}$, aplicadas via água em $\mathrm{kg} \mathrm{ha}^{-1}$, foram maiores em função do maior volume de água utilizado neste experimento, sendo os tratamentos definidos como:

0 - tratamento sem cobertura, sem adição de $\mathrm{CO}_{2}$;

$0 \mathrm{M}$ - tratamento com cobertura e sem a adição de $\mathrm{CO}_{2}$;

300 - tratamento sem cobertura com uso de $71 \mathrm{~kg} \mathrm{ha}^{-1}$ de $\mathrm{CO}_{2}$;

$300 \mathrm{M}$ - tratamento com cobertura e com uso de $71 \mathrm{~kg} \mathrm{ha}^{-1} \mathrm{de} \mathrm{CO}_{2}$;

600 - tratamento sem cobertura e com uso de $199 \mathrm{~kg} \mathrm{ha}^{-1}$ de $\mathrm{CO}_{2}$;

$600 \mathrm{M}$ - tratamento com cobertura e com uso de $199 \mathrm{~kg} \mathrm{ha}^{-1}$ de $\mathrm{CO}_{2}$;

900 - tratamento sem cobertura e com uso de $365 \mathrm{~kg} \mathrm{ha}^{-1}$ de $\mathrm{CO}_{2} \mathrm{e}$ $900 \mathrm{M}$ - tratamento com cobertura e com uso de $365 \mathrm{~kg} \mathrm{ha}^{-1}$ de $\mathrm{CO}_{2}$;

A disposição do experimento no campo foi semelhante a do primeiro experimento.

\subsubsection{Variáveis analisadas do solo}

Em cada subparcela, foi colocado um extrator de solução, de cápsula porosa, a $15 \mathrm{~cm}$ de profundidade. Semanalmente, eram coletadas amostras dessa solução e determinavam-se o $\mathrm{pH}$ e a condutividade elétrica (CE) em $\mathrm{dS} \mathrm{m}^{-1}$.

\subsubsection{Variáveis analisadas da planta}

\subsubsection{Análise do crescimento e da absorção de nutrientes pela cultura}

Durante o experimento de campo, uma planta representativa por subparcela foi retirada aos 17 DAT, 28 DAT, 64 DAT e 76 DAT, para a análise dos 
macro e micronutrientes contidos nas folhas, nos pecíolos, nos caules e nos frutos, seguindo-se a metodologia de Sarruge \& Haag (1974). O objetivo foi conhecerem-se os efeitos dos tratamentos na absorção desses nutrientes. Posteriormente, essas mesmas plantas foram levadas à estufa de circulação forçada com temperatura entre 65 e $70^{\circ} \mathrm{C}$, para a obtenção da massa de material seco da parte aérea.

Para as plantas retiradas aos 64 DAT, procedeu-se à determinação da área foliar com o analisador LI-3100 (LI-COR, Lincoln, Nebraska). Nesse mesmo período, as raízes das plantas foram retiradas e submetidas a secagem, para a obtenção da massa de material seco. De posse de tais dados, procedeu-se ao cálculo da razão percentual entre a massa de material seco da parte aérea e a das raízes.

\subsubsection{Número de frutos e rendimento}

Os frutos foram colhidos diariamente no ponto comercial e pesados individualmente em cada colheita. $\mathrm{O}$ rendimento foi estimado em $\mathrm{kg} \mathrm{ha}^{-1}$ para cada tratamento.

\subsubsection{Análise econômica}

A estimativa dos custos operacionais e das exigências físicas dos fatores de produção de abobrinha italiana foram fornecidos pelo Sindicato Rural de Mogi das Cruzes, para o ano de 1999, sendo o valor de $\mathrm{R} \$ 4.546,63$ por hectare. As despesas com o uso da cobertura plástica e a adição de $\mathrm{CO}_{2}$, via irrigação, foram estimadas com base nos gastos feitos no projeto. Para o emprego do $\mathrm{CO}_{2}$, foram considerados dois cilindros com 25 L do gás, reguladores de pressão e fluxômetro para custos fixos, resultando em $\mathrm{R} \$ 1.400,00$; para custos variáveis foi considerada a recarga do $\mathrm{CO}_{2}$ de $\mathrm{R} \$ 2,50$ o $\mathrm{kg}$ do gás, enquanto, para custos anuais de reposição e manutenção, foram considerados abraçadeiras, mangueiras, tubo injetor, no valor de $\mathrm{R} \$ 200,00$. O custo da cobertura

plástica foi de $\mathrm{R} \$ 0,35$ por $\mathrm{m}^{2}$, adicionado à mão-de-obra para sua instalação, no valor de $\mathrm{R} \$ 160,00$. 
Os preços do quilograma de abobrinha foram calculados com base em levantamento de preços dos produtos agrícolas, feito nos boletins mensais fornecidos pela CEAGESP (2001), abrangendo os anos de 1995 a 1999. Foram considerados três valores por quilograma do produto vendido no atacado, para a abobrinha de classificação Extra A, sendo de $\mathrm{R} \$ 0,24$, o menor valor ; $\mathrm{R} \$ 0,38$, o valor médio e $\mathrm{R} \$ 0,51$, o maior valor.

Os custos fixos foram corrigidos pelo fator de recuperação de capital (FRC) conforme a equação apresentada por Bernardo (1995). Para o cálculo da depreciação dos custos fixos, foram consideradas uma vida útil de 10 anos e uma taxa de juros de $12 \%$ ao ano. A análise da viabilidade econômica para os dois experimentos foi feita utilizando-se a razão benefício custo, que mostra ser o projeto economicamente viável, quando o valor é maior que 1. 


\section{RESULTADOS E DISCUSSÃO}

\subsection{Experimento I}

\subsubsection{Elementos meteorológicos}

Os dados meteorológicos, observados durante o experimento, revelaram temperaturas mínimas absolutas muito baixas (Tabela 8). Segundo a ESALQ (2001), as temperaturas mínimas absolutas, observadas em maio, apresentam média histórica de $6,5^{\circ} \mathrm{C}$, enquanto, no ano de 2000 , foram verificadas as mais baixas temperaturas dos últimos 21 anos. Esses valores ocorreram logo após o transplante das mudas, provocando danos à cultura e uma redução no "stand". Posteriormente, foram observadas temperaturas baixas, quando as plantas já estavam na fase de produção, provocando danos às folhas (Figura 4). A literatura é unânime em afirmar que a cultura tolera temperaturas amenas, entretanto não suporta as geadas (Camargo, 1981; Filgueira, 2000; Maroto, 1995).

As temperaturas de relva apresentaram valores mínimos sempre superiores, nas parcelas com cobertura plástica, em comparação ao solo nu, enquanto a temperatura máxima foi equivalente. Isso indica uma menor amplitude térmica com o uso do plástico (Figura 5), mas a cobertura plástica sobre o solo não foi capaz de evitar danos na cultura devido às baixas temperaturas, embora tenha mantido o solo mais aquecido.

Com as leituras dos geotermômetros a $10 \mathrm{~cm}$ de profundidade, procedeut se ao cálculo da variação de temperatura entre os posicionados nas subparcelas, com mulch, e os das subparcelas, sem mulch, observando-se uma variação de até $4,8{ }^{\circ} \mathrm{C}$. 
Resultados similares foram obtidos por Abdul-Baki et al.(1992), que observaram um aumento de cerca de $5^{\circ} \mathrm{C}$ com o uso do mulch. Mormeneo \& Cantamutto (1999) observaram aumentos de temperaturas médias significativas, com o uso do mulch, na ordem de $3,7^{\circ} \mathrm{C}$ e $4,1^{\circ} \mathrm{C}$, durante o verão na Argentina. Sampaio (1996) observou que as temperaturas máximas e mínimas foram mais elevadas e os gradientes entre elas foram menores no solo com mulch.

A primeira colheita ocorreu aos 41 DAT e a última, aos 72 DAT. Aparentemente, não foi observada antecipação no ciclo nos tratamentos com mulch. Contrariamente, alguns pesquisadores observaram adiantamento das fases de culturas hortícolas, com o uso do mulch (Bhella, 1988; Sandres, 1996; Mormeneo \& Cantamutto,1999; Ibarra et al., 2001).

Tabela 8 . Elementos climáticos observados na área durante o primeiro experimento. Fazenda Areão. Piracicaba, SP. 2000.

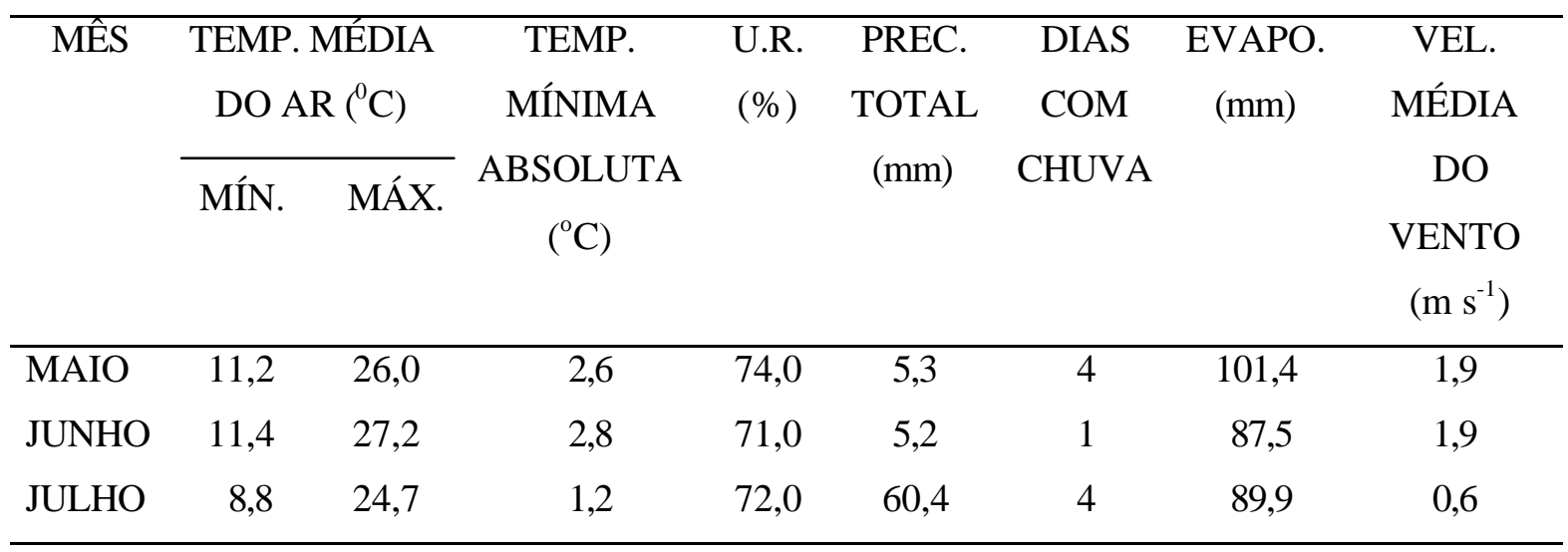



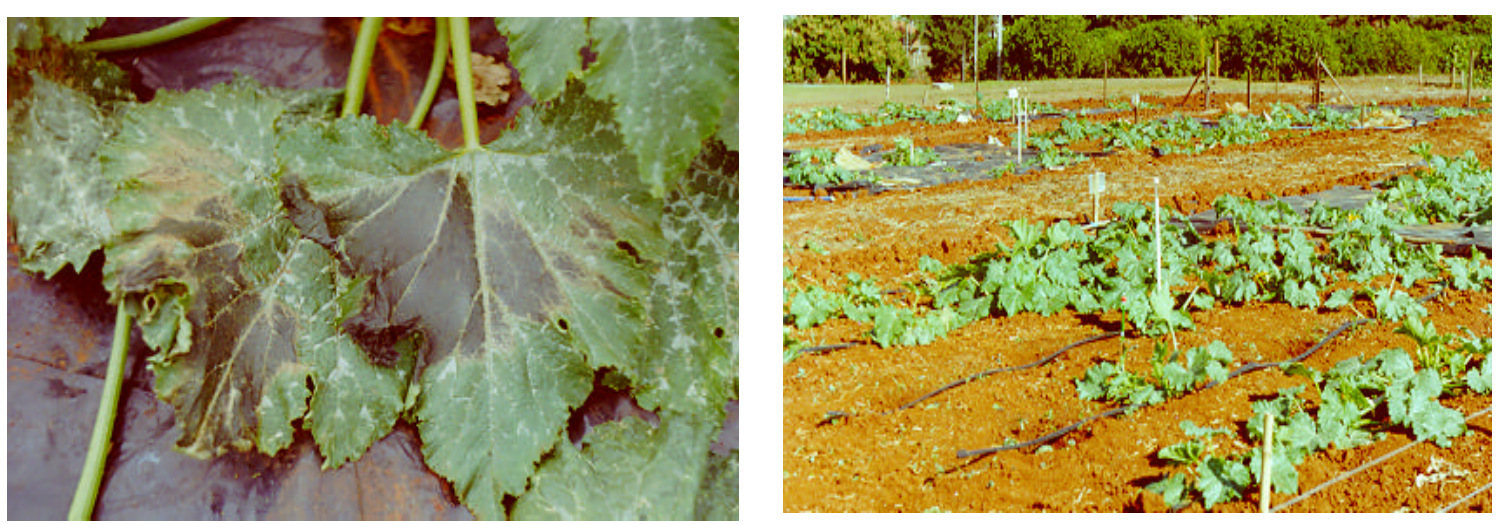

Figura 4 - Danos causados na abobrinha devido às baixas temperaturas do ar. Observamse queimas nas folhas e redução no "stand" .



Figura 5 - Valores diários de temperaturas de relva máxima e mínima observados durante o primeiro experimento. Piracicaba, SP. 2000.

\subsubsection{Manejo da irrigação}

Para o manejo da irrigação, utilizaram-se até os 35 DAT, os valores de Kc, citados por Klosowski et al. (1999) para a abobrinha. Entretanto, tais valores, que variam de 0,68 a 1,96 para todo o ciclo, mostraram-se altos, o que levou à aplicação excessiva de água no experimento. Isso foi detectado pelo monitoramento feito com os 
tensiômetros. Os próprios autores comentam que os valores excessivos de Kc se devem aos cálculos feitos em relação à evapotranspiração de referência, obtida em grama, e à manutenção de um lençol freático constante. Devido a essa constatação, a partir dos 36 DAT, optou-se por um Kc de 0,7 para todo o ciclo, com base em Doorenbos \& Pruitt (1997) para a cultura da abóbora, exceto para o período entre 45 e 68 DAT, que foi de 0,9 .

A lâmina de água aplicada à cultura, durante o ciclo de cerca de 70 dias, foi de $110,0 \mathrm{~mm}$. No período, o total de chuvas foi de $65,6 \mathrm{~mm}$, resultando num total de 175,6 mm. O total evaporado pelo tanque Classe A, de 23 de maio a 31 de julho, foi de $197,6 \mathrm{~mm}$.

Adotou-se, como critério, a manutenção do solo para a cultura sempre próximo à capacidade de campo. Com base nas tensões observadas na Figura 6, verificase que o solo permaneceu com potenciais um pouco superiores a $-6 \mathrm{kPa}$ na maior parte do período de cultivo, evidenciando uma aplicação de água excessiva. O solo sob cobertura plástica apresentou sempre leituras de potenciais superiores às do solo nu. Entretanto não foram observados danos fitossanitários à cultura, sendo que as elevações drásticas de leituras de potencial coincidiram com as precipitações ocorridas no período.

Cocucci et al. (1976) sugeriram que maiores produções de frutos da abobrinha estão diretamente relacionadas a uma melhor disponibilidade de água. $\mathrm{Na}$ literatura, os trabalhos sobre cobertura plástica apresentam evidências de maior retenção de umidade, quando comparadas aos do solo nu (Bhella, 1988; Sandres, 1996; Sampaio, 1996; Mormeneo \& Cantamutto,1999; Ibarra et al., 2001). 




Figura 6 - Leitura dos tensiômetros (- kPa) a $10 \mathrm{~cm}$ de profundidade, nas parcelas sob cobertura plástica (Mulch) e sob solo nu, durante o período experimental.

\subsubsection{Uso da água carbonatada}

No momento da irrigação, a água dos gotejadores e a contida na caixa d'água (fonte), a qual abastecia o experimento, foram coletadas para leituras do $\mathrm{pH}$ e da CE (Figura 7).

Houve uma redução no $\mathrm{pH}$ da água dos tratamentos que utilizavam o $\mathrm{CO}_{2}$, em virtude da formação de ácido carbônico. No geral, essas reduções estiveram sempre ligadas às doses de $\mathrm{CO}_{2}$, ou seja, as doses maiores promoveram maiores reduções no $\mathrm{pH}$. Em termos médios, ao longo do experimento, os valores do $\mathrm{pH}$ na água foram de 7,5;7,3;6,8;6,0 e 5,7 para a fonte e os tratamentos 0, 300, 600 e 900, respectivamente. Resultados semelhantes foram evidenciados por outros autores, quando ocorreram reduções no $\mathrm{pH}$ da água com a adição de $\mathrm{CO}_{2}$ (Mauney \& Hendrix, 1988; D’Andria et al., 1993; Moore, 1990; Hartz \& Holt ,1991; Guri et al.,1999). 
Enoch \& Olesen (1993) comentaram que, do $\mathrm{CO}_{2}$ aplicado, somente $1 \%$ forma ácido carbônico, o qual se transforma em $\mathrm{HCO}_{3}{ }^{-}$e $\mathrm{CO}_{3}{ }^{2}$, reduzindo o $\mathrm{pH}$ da água; o restante permanece dissolvido na água e deixa o solo na forma de gás. Isso sugere que a importância maior do uso do $\mathrm{CO}_{2}$ seja o enriquecimento da atmosfera. Entretanto Storlie \& Heckman (1996b) sugeriram que o benefício potencial da água carbonatada seja a redução temporária do $\mathrm{pH}$ no solo, o que disponibilizaria nutrientes para a planta. Baker (1988) citou que outro benefício da redução do pH seria o aumento da atividade de certos microorganismos do solo.

A condutividade elétrica (CE) da água proveniente dos gotejadores dos tratamentos e da fonte apresentou valores semelhantes, exceto aos 17, 34 e 43 DAT, estando essa diferença associada à fertirrigação (Figura 7). No geral, a água da fonte apresentou uma CE de 0,275 dS $\mathrm{m}^{-1}$. Ayers \& Westcot (1991) comentam que a água de irrigação deve possuir pH entre 6,5 e 8,4 e CE maior que $0,2 \mathrm{dS} \mathrm{m}^{-1}$; caso contrário, ou seja, águas com valores de $\mathrm{pH}$ e $\mathrm{CE}$ fora dessa faixa podem causar desequilíbrios nutricionais na cultura e problemas físicos ao solo. Nesse caso, os autores sugerem uma análise mais completa da água.
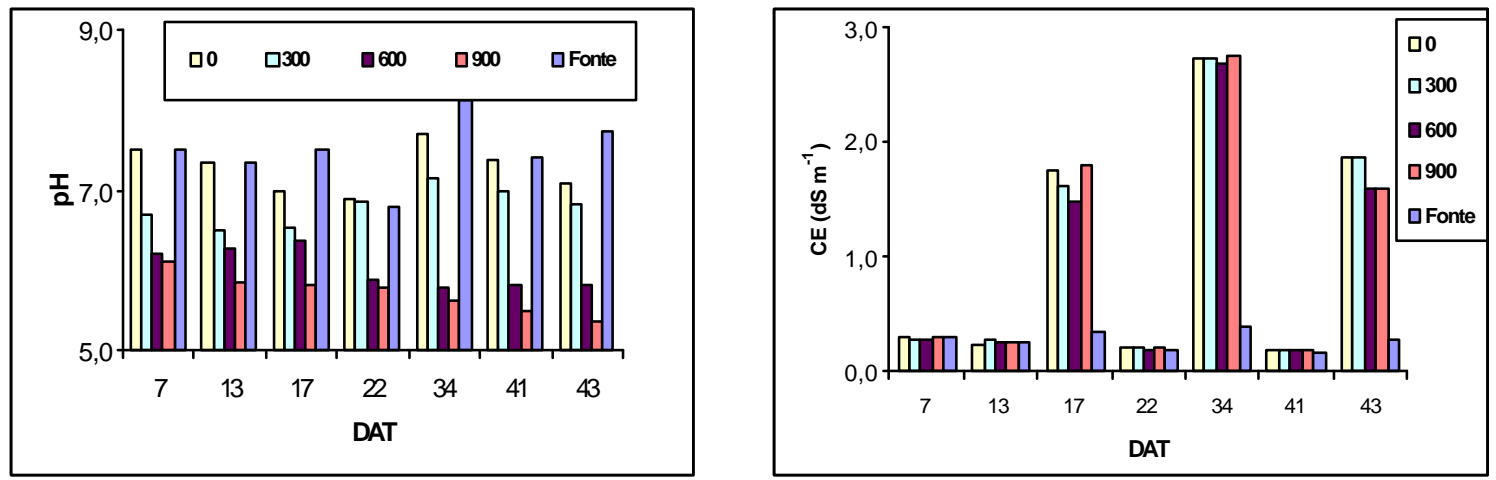

Figura 7 - Valores de $\mathrm{pH}$ e $\mathrm{CE}\left(\mathrm{dS} \mathrm{m}^{-1}\right)$ da água coletada na fonte e nos gotejadores dos tratamentos 0, 300, 600, 900, durante a aplicação de água carbonatada no experimento. 
Os teores de $\mathrm{CO}_{2}$ no ar pouco se alteraram com a adição de água carbonatada nas parcelas, (Figura 8). Em geral, os níveis observados durante o período ficaram acima de $420 \mathrm{mg} \mathrm{L}^{-1}$, superiores, portanto, aos $360 \mathrm{mg} \mathrm{L}^{-1}$ que normalmente se supõe existirem no ar (Vitousek, 1991). Isso pode ser atribuído ao aumento nos níveis de $\mathrm{CO}_{2}$ na atmosfera, devido ao período de realização do experimento coincidir com a época de queimadas na região, em virtude da colheita da cana-de-açúcar. No dia 21 de julho, os teores de $\mathrm{CO}_{2}$ no ar apresentaram uma elevação, com a adição de $\mathrm{CO}_{2}$ na água de irrigação, nos tratamentos, após a irrigação, entretanto, essa elevação foi de, no máximo, $7 \%$.

Em outra medida, dia 27 de julho, alguns tratamentos também apresentaram a mesma tendência de aumento, durante a irrigação. Vê-se que os valores se elevaram com a adição da água carbonatada, mas que não atingiram teores altos em nenhum dos tratamentos (Figura 8). Alguns trabalhos reportam sobre os níveis de $\mathrm{CO}_{2}$ aéreo com o uso da água carbonatada: Novero et al. (1991) observaram elevação nos níveis de $\mathrm{CO}_{2}$ aéreo a $1 \mathrm{~cm}$ e a $15 \mathrm{~cm}$ de altura, em relação à superfície do solo, quando da aplicação de água carbonatada.
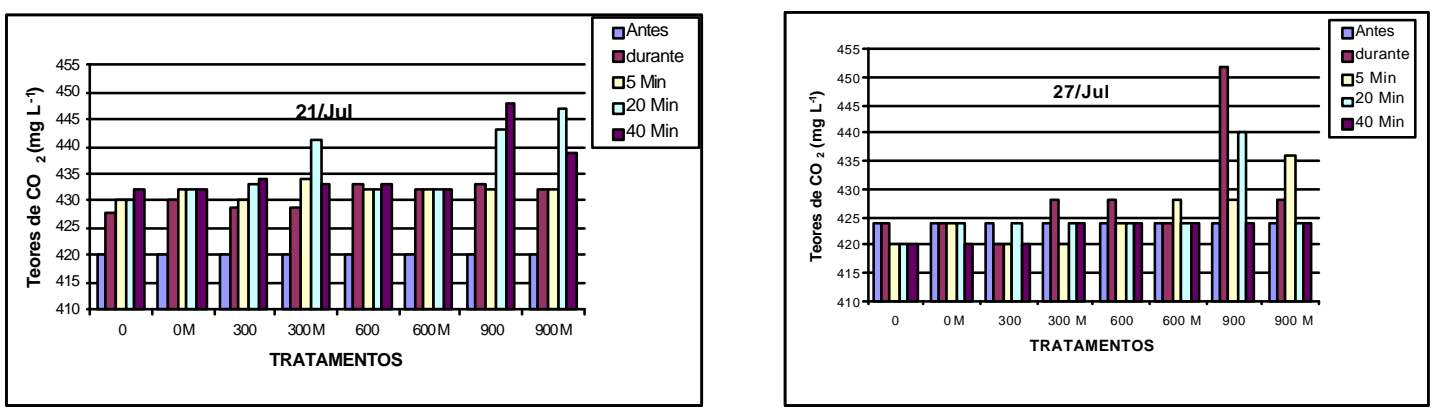

Figura 8 - Valores do teor de $\mathrm{CO}_{2}$ no ar $\left(\mathrm{mg} \mathrm{L}^{-1}\right)$ captados nos diferentes tratamentos nos dias 21/julho e 27/julho de 2000, antes, durante e após a irrigação.

Por outro lado, Storlie \& Heckman (1996a) analisaram uma série de outros experimentos em que se mediu o perfil de $\mathrm{CO}_{2}$, verificando que pouca ou 
nenhuma elevação nos teores de $\mathrm{CO}_{2}$ aéreo ocorreu, e atribuiu isso à velocidade do vento sobre o experimento, durante as medidas.

\subsubsection{Análise de crescimento}

A área foliar foi influenciada significativamente, em nível de $5 \%$ de probabilidade pelo teste $\mathrm{F}$, pelos fatores dose e cobertura do solo. A Tabela 9 mostra as equações de regressão ajustadas para a área foliar $\left(\mathrm{cm}^{2}\right)$ da abobrinha, aos 68 DAT. Foi possível ajustar-se um modelo quadrático, que explica 53,1\% das variações da variável dependente dentro do solo nu, com um ponto de máxima obtido com 129,9 $\mathrm{kg} \mathrm{ha}^{-1}$ de $\mathrm{CO}_{2}$. Para o solo coberto, foi ajustado um modelo quadrático que explica $57,0 \%$ das variações, com ponto de máximo de $86,5 \mathrm{~kg} \mathrm{ha}^{-1}$ de $\mathrm{CO}_{2}$.

Resultados semelhantes foram obtidos por Guri et al. (1999), quando aplicaram $\mathrm{CO}_{2}$ em solução nutritiva e obtiveram incrementos na área foliar em plantas de pimentão. Acock et al. (1990) observaram aumentos de área foliar e de material vegetal seco das folhas em melão, quando aplicaram dióxido de carbono via ar. Vessey et al. (1990) também verificaram aumentos nos níveis de $\mathrm{N}$ total e área foliar, mas não no número de folhas, ao estudarem o efeito da elevação da concentração do $\mathrm{CO}_{2} \mathrm{em}$ plantas de soja. Mudrik et al. (1997) observaram aumentos de 30\% na área foliar e 54\% na biomassa de ervilha e atribuíram os resultados às condições gerais de melhoria da nutrição mineral, acrescida de uma boa translocação de assimilados.

Tabela 9. Equações de regressão para a área foliar $\left(\mathrm{cm}^{2}\right)$ de abobrinha aos 68 DAT em função das doses de $\mathrm{CO}_{2}(\mathrm{X})$ via água de irrigação e da cobertura do solo. Piracicaba, SP, 2000

\begin{tabular}{lcc}
\hline Área Foliar $\left(\mathrm{cm}^{2}\right)$ & Equação de Regressão & $\mathrm{R}^{2}$ \\
\hline Para solo nu & $\mathrm{Ye}=7594,2086+27,2578^{*} . \mathrm{X}-0,1049^{*} . \mathrm{X}^{2}$ & 0,531 \\
Para solo coberto & $\mathrm{Ye}=10831,9721+13,4672^{\circ} . \mathrm{X}-0,0778^{\circ} . \mathrm{X}^{2}$ & 0,570 \\
\hline${ }^{\circ},{ }^{*}$, significativos a 10 e 5\% de probabilidade, respectivamente, pelo teste t. &
\end{tabular}


A massa de material seco da parte aérea (MMSPA) e das raízes (MMSR) foi influenciadas pela água carbonatada e pela cobertura plástica do solo, não havendo interação entre os fatores. A Figura 9 mostra as médias da massa de material seco (g) da parte aérea e a equação de regressão ajustada para a variável no solo nu. Foi possível ajustar uma modelo linear crescente para essa variável.

A massa de material seco (g) da parte aérea das plantas, com cobertura plástica, apresentou valores significativamente maiores pelo teste de Tukey, no nível de $5 \%$ de probabilidade, em relação a seus pares em solo descoberto. Porém não foi possível ajustar uma equação com significado biológico para a variável, sendo a média geral da MMSPA 168,6 g. Resultados semelhantes foram obtidos por Bhella \& Kwolek (1984) e Abdul-Baki et al. (1992), quando a cobertura plástica do solo estimulou o crescimento da cultura. Os autores concluíram que a elevação de temperatura do solo, propiciada pelo plástico, estimulou uma maior absorção de água e nutrientes.

Vários trabalhos observaram o aumento da biomassa com a adição de $\mathrm{CO}_{2}$ (Mauney \& Hendrix, 1988; Novero et al., 1991; Idso \& Idso, 1994). A influência das doses de $\mathrm{CO}_{2}$ sobre o crescimento da massa aérea é discutida na literatura como resultado do estímulo na absorção de nutrientes, quando ocorre a redução do $\mathrm{pH}$ do solo (Moore, 1990); o aumento da atividade biológica do solo (Baker, 1988); a assimilação de carbono diretamente pelo sistema radicular (Arteca et al., 1979; Arteca \& Poovaiah, 1982; Baron \& Gorski, 1986) e o aumento na atividade fotossintética (Harper et al., 1973) também são discutidos. 


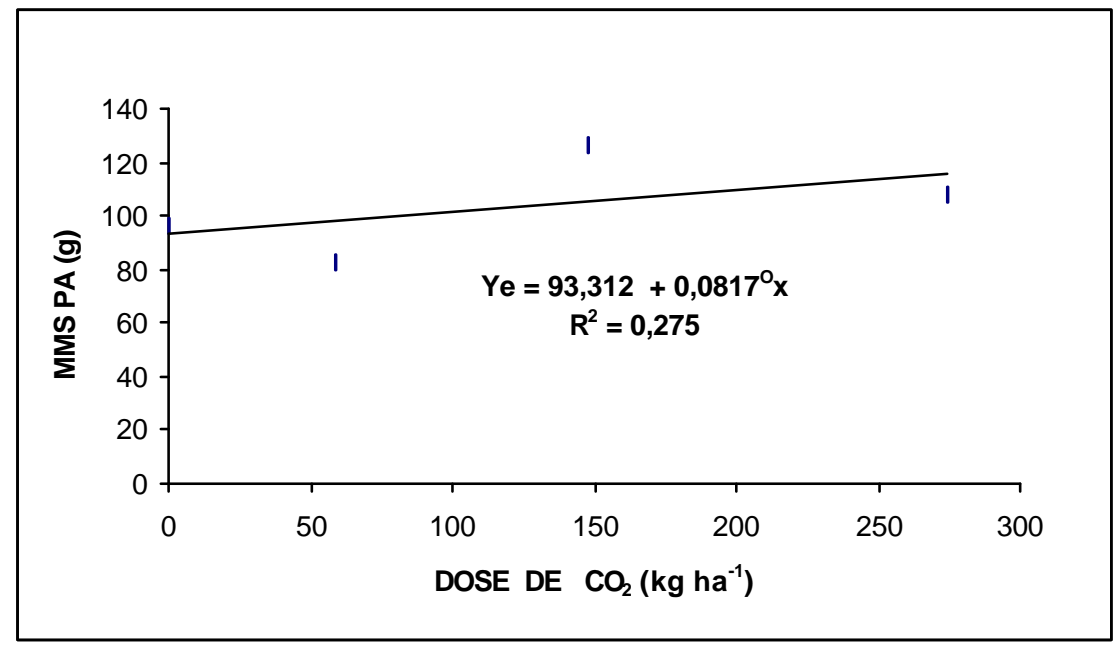

${ }^{\circ}$, significativo a $10 \%$ de probabilidade pelo teste $\mathrm{t}$

Figura 9 - Médias da massa de material seco da parte aérea (MMSPA), em g, de abobrinha, em função das doses de $\mathrm{CO}_{2}$ via água de irrigação, e equação de regressão para dados em solo nu. Piracicaba, SP, 2000.

Em relação ao sistema radicular, não foi possível ajustar equações de regressão com significado biológico em função dos tratamentos. No geral, a média da massa de material seco das raízes (g) foi de 4,45 g. Visualizou-se que o sistema radicular da abobrinha foi superficial, concentrando-se nos primeiros $15 \mathrm{~cm}$ de profundidade do solo, mas possuía uma extensão superior a $2 \mathrm{~m}$, ficando paralelo à linha de gotejo. Supostamente, o sistema de irrigação localizada com frequiência diária de aplicação de água, associado à fertirrigação, definiram esse perfil de raízes.

Vários autores também comentam que o sistema de irrigação localizado estimula as plantas ao desenvolvimento superficial das raízes, havendo concentração próxima aos emissores (Bhella, 1988; Sampaio,1996). Makishima \& Miranda (1992) reportam também que o uso da cobertura plástica sobre o solo propicia o crescimento superficial das raízes. Filgueira (2000) comenta, ainda, que a abobrinha apresenta sistema radicular superficial naturalmente, enquanto Fontes \& Lima (1993) enfatizaram que as raízes da abobrinha são do tipo fasciculado, concentrando-se numa porção superficial, e com grande crescimento lateral. 


\subsubsection{Número de frutos e rendimento}

$\mathrm{Na}$ Tabela 10, estão o número médio de frutos (frutos $\mathrm{ha}^{-1}$ ) e o rendimento $\left(\mathrm{kg} \mathrm{ha}^{-1}\right)$ de abobrinha. Ambas as varáveis dependentes foram influenciadas tanto pela cobertura plástica quanto pela água carbonatada, sendo significativa a interação entre os fatores. Entretanto não foram observadas diferenças significativas, quando comparados o número médio de frutos dos tratamentos sem cobertura plástica aos seus respectivos pares com cobertura, acontecendo quanto ao rendimento de abobrinha o mesmo fato.

Tabela 10. Número de Frutos (Frutos $\mathrm{ha}^{-1}$ ) e rendimento $\left(\mathrm{kg} \mathrm{ha}^{-1}\right)$ de abobrinha cultivada com água carbonatada em solo com e sem cobertura plástica.

\begin{tabular}{|c|c|c|c|c|}
\hline \multirow{2}{*}{$\begin{array}{c}\text { Dose de } \mathrm{CO}_{2} \\
\left(\mathrm{~kg} \mathrm{ha}^{-1}\right)\end{array}$} & \multicolumn{2}{|c|}{ Número de Frutos (Frutos ha ${ }^{-1}$ ) } & \multicolumn{2}{|c|}{ Rendimento $\left(\mathrm{kg} \mathrm{ha}^{-1}\right)$} \\
\hline & Sem Cobertura & Com cobertura & Sem Cobertura & Com cobertura \\
\hline 0 & $63.000 \mathrm{a}$ & $88.750 \mathrm{a}$ & $9.327 \mathrm{a}$ & $14.427 \mathrm{a}$ \\
\hline 59 & $88.333 \mathrm{a}$ & $100.889 \mathrm{a}$ & $14.322 \mathrm{a}$ & $16.356 \mathrm{a}$ \\
\hline 148 & $66.250 \mathrm{a}$ & $86.250 \mathrm{a}$ & $9.331 \mathrm{a}$ & $13.482 \mathrm{a}$ \\
\hline 274 & $41.000 \mathrm{a}$ & $61.667 \mathrm{a}$ & $5.886 \mathrm{a}$ & $7.886 \mathrm{a}$ \\
\hline
\end{tabular}

Para a variável, médias seguidas da mesma letra na horizontal, não diferiram estatisticamente entre si a $5 \%$ de probabilidade pelo teste de Tukey.

Modelos quadráticos foram ajustados para número de frutos, explicando 93,1\% e 79,6 \% dos resultados para solo coberto e solo nu, respectivamente (Figura 10). Para o solo coberto, a produtividade máxima foi de 95.281 frutos ha $^{-1}$, para a dose de $68,5 \mathrm{~kg} \mathrm{ha}^{-1}$ de $\mathrm{CO}_{2}$, enquanto para o solo nu, a produtividade máxima foi 77.908 frutos ha $^{-1}$ para a dose de $90,6 \mathrm{~kg} \mathrm{ha}^{-1}$ de $\mathrm{CO}_{2}$. 


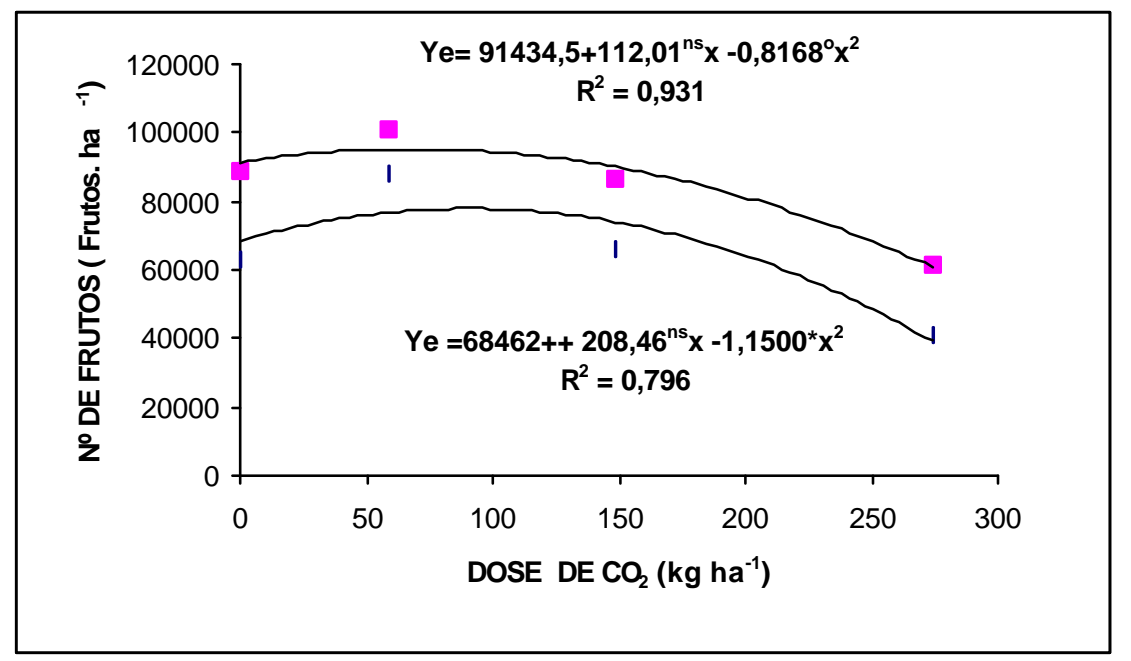

$\mathrm{ns},{ }^{\circ}, *$, não significativo e significativos a 10 e $5 \%$ de probabilidade, respectivamente, pelo teste $\mathrm{t}$

Figura 10 - Número médio de frutos (frutos $\mathrm{ha}^{-1}$ ) de abobrinha e equações de regressão em função das doses de $\mathrm{CO}_{2}$ aplicadas via água de irrigação para solo nu $(\bullet)$ e coberto (ם). Piracicaba, SP, 2000.

O aumento no rendimento de frutos, como conseqüência da irrigação com água carbonatada e o uso de cobertura plástica, coincide com outros estudos realizados com algodão, pepino, melão e pimentão (Mauney \& Hendrix, 1988; Ibrahim, 1992; Pinto, 1997 e Guri et al. ,1999). Os aumentos observados na área foliar e na massa de material seco da parte aérea influenciaram os resultados, propiciando aumento na produção de frutos.

Verificourse, pela análise de variância, que o rendimento comercial $\left(\mathrm{kg} \mathrm{ha}^{-1}\right.$ ) de abobrinha foi influenciado pelas doses de $\mathrm{CO}_{2}$ e pela cobertura do solo, não havendo interação entre tais fatores. O uso da água carbonatada, associado à cobertura plástica, influenciou positivamente a produção. Os tratamentos, com uma determinada dose de $\mathrm{CO}_{2}$ e com cobertura plástica, foram mais produtivos que seus pares em solo nu, supostamente pela melhoria nas condições térmicas, pela boa manutenção hídrica do solo e pela maior disponibilidade de $\mathrm{CO}_{2}$ para as plantas, uma vez que o gás não se dissipa tão rapidamente sob a influência do vento. 
A Figura 11 apresenta os modelos quadráticos, ajustados para o rendimento de frutos.

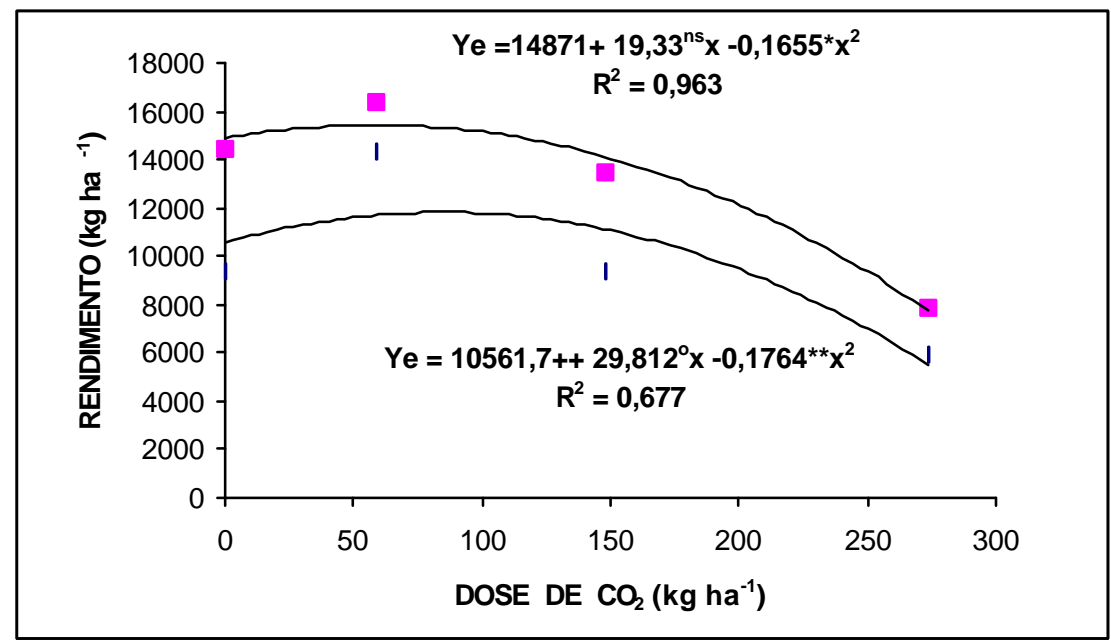

ns, ${ }^{\circ}, *, * *$, não significativo e significativos a 10,5 e $1 \%$ de probabilidade, respectivamente, pelo teste $\mathrm{t}$

Figura 11 - Rendimento de frutos $\left(\mathrm{kg} \mathrm{ha}^{-1}\right)$ de abobrinha e equações de regressão em função das doses de $\mathrm{CO}_{2}$ aplicadas via água de irrigação para solo nu $(\bullet)$ e coberto (ם). Piracicaba, SP, 2000.

Para o experimento, a eficiência máxima de rendimento foi de $15.435 \mathrm{~kg} \mathrm{ha}^{-1}$, com o uso de $58,4 \mathrm{~kg} \mathrm{ha}^{-1}$ de $\mathrm{CO}_{2}$, associado à cobertura plástica do solo. Esse rendimento foi $65 \%$ superior ao do tratamento-testemunha, que foi de $9.328 \mathrm{~kg} \mathrm{ha}^{-1}$. Esses resultados são convergentes com aqueles encontrados por Pinto (1997), que obteve, com a aplicação de $50 \mathrm{~kg} \mathrm{ha}^{-1}$ de $\mathrm{CO}_{2}$ via água, aumento de $70 \%$ na produtividade comercial de melão. Outros autores, utilizando água carbonatada, também encontraram incremento de $50 \%$ na produção de algodão (Mauney \& Hendrix, 1988), 30\% em pepino (Ibrahim, 1992), 8,7\% em tomate (Cararo, 2000) e 10\% em pimentão (Guri et al., 1999).

Por outro lado, Hartz \& Holt (1991) estudaram o efeito do $\mathrm{CO}_{2}$, aplicado via água de irrigação sobre as culturas de tomate e da abóbora em campo, e não observaram qualquer aumento de produção. Segundo Storlie \& Heckman (1996b), 
apesar dos resultados positivos da água carbonatada para a cultura, existe uma série de fatores ainda não compreendidos que levam a resultados inconsistentes, fazendo com que, em termos práticos, ainda não seja recomendado o uso dessa técnica.

A média geral do experimento foi de $11.378 \mathrm{~kg} \mathrm{ha}^{-1}$, considerando-se bons rendimentos segundo Filgueira (2000). Entretanto os valores foram inferiores aos obtidos por Silva et al. (1988) e Lunardi et al. (1999).

\subsubsection{Análise da solução do solo}

A Figura 12 apresenta os teores dos macronutrientes minerais, o $\mathrm{pH}$ e a CE da solução do solo. Em todos os tratamentos, o cálcio foi o elemento predominante na solução do solo, influenciando a CE observada, enquanto o pH apresentou uma ligeira elevação com a adição de $\mathrm{CO}_{2}$. Nos tratamentos 600 e $600 \mathrm{M}$, verificoutse uma tendência de maior disponibilidade de $\mathrm{Ca}$ e $\mathrm{Mg}$, em relação aos demais tratamentos.

Isso talvez tenha ocorrido porque a água carbonatada aumentou a disponibilidade dos cátions $\mathrm{Ca}$ e $\mathrm{Mg}$, ao trocá-los por $\mathrm{H}$, liberando-os para a solução, tornando-os prontamente disponíveis à cultura. Cararo (2000) também observou elevação no teor de cálcio na solução do solo, com o uso de água carbonatada e o acompanhamento dessa tendência em função da CE.
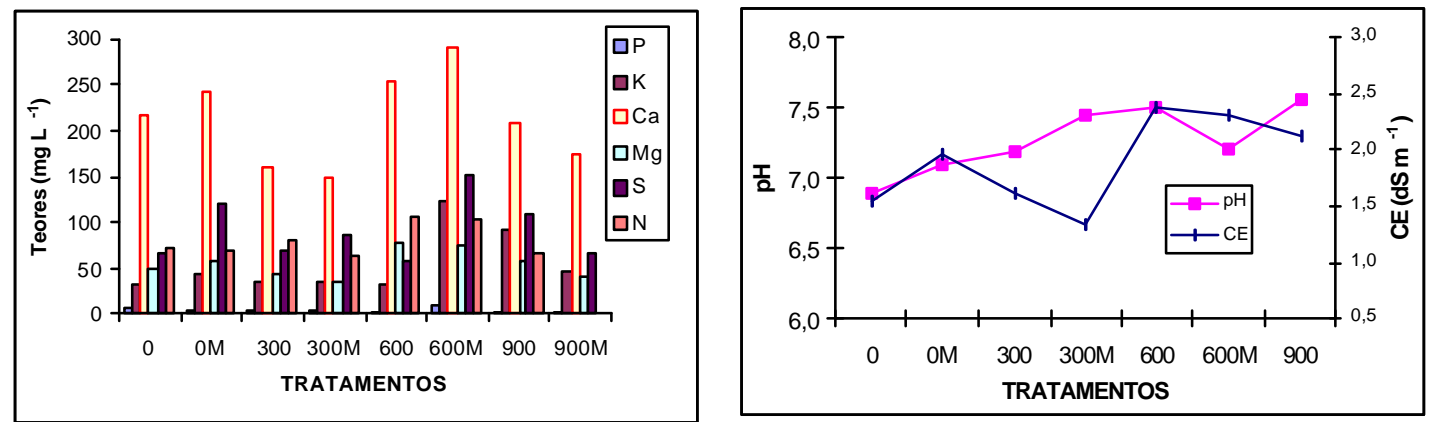

Figura 12 - Teores de alguns macronutrientes $\left(\mathrm{mg} \mathrm{L}^{-1}\right), \mathrm{pH}$ e $\mathrm{CE}\left(\mathrm{dS} \mathrm{m}{ }^{-1}\right)$ da solução do solo em função dos tratamentos. Piracicaba, 2000. 


\subsubsection{Análise das folhas e dos frutos}

Aos 39 DAT, próximo à primeira colheita, coletou-se uma amostra composta em cada tratamento, para a análise química das folhas (Tabela 11). Aparentemente, não foram observadas alterações nas concentrações dos elementos quando do uso da água carbonatada associado, ou não, ao uso da cobertura plástica. A sequiência crescente de macronutrientes presentes nas folhas foi: $\mathrm{K}>\mathrm{N}>\mathrm{Ca}>\mathrm{Mg}>\mathrm{P}>\mathrm{S}$, enquanto a de micronutrientes foi: $\mathrm{Fe}>\mathrm{Mn}>\mathrm{Zn}>\mathrm{B}$.

Exceto para boro, os teores nas folhas para os nutrientes analisados encontram-se acima ou na faixa dos limites recomendados por Mills \& Jones Junior (1996), para a cultura da abobrinha, que são: 40 a $60 \mathrm{~g} \mathrm{~kg}^{-1}$ para $\mathrm{N} ; 3$ a $5 \mathrm{~g} \mathrm{~kg}^{-1}$ para P; 30 a $50 \mathrm{~g} \mathrm{~kg}^{-1}$ para $\mathrm{K} ; 12$ a $25 \mathrm{~g} \mathrm{~kg}^{-1}$ para Ca; 3 a $10 \mathrm{~g} \mathrm{~kg}^{-1}$ para $\mathrm{Mg}$; 50 a $200 \mathrm{mg} \mathrm{kg}^{-1}$ para Fe; 50 a $250 \mathrm{mg} \mathrm{kg}^{-1}$ para $\mathrm{Mn} ; 25$ a $75 \mathrm{mg} \mathrm{kg}^{-1}$ para B e 20 a $200 \mathrm{mg} \mathrm{kg}^{-1}$ para $\mathrm{Zn}$.

Tabela 11 . Teores de nutrientes em folhas de abobrinha, cultivadas com água carbonatada e cobertura plástica (M). Piracicaba, 2000.

\begin{tabular}{|c|c|c|c|c|c|c|c|c|c|c|}
\hline \multirow[t]{2}{*}{ Trat. } & $\mathrm{N}$ & $P$ & $\mathrm{~K}$ & $\mathrm{Ca}$ & $\overline{\mathrm{Mg}}$ & $\mathrm{S}$ & $\mathrm{B}$ & $\mathrm{Fe}$ & $\mathrm{Mn}$ & $\mathrm{Zn}$ \\
\hline & & & \multicolumn{4}{|c|}{$\mathrm{g} \mathrm{kg}^{-1}$} & & \multicolumn{3}{|c|}{$\mathrm{mg} \mathrm{kg}^{-1}$} \\
\hline 0 & 50,3 & 5,7 & 58,1 & 23,5 & 7,4 & 1,6 & 16,2 & 167,0 & 88,0 & 65,5 \\
\hline $0 \mathrm{M}$ & 47,7 & 5,5 & 59,7 & 27,9 & 7,3 & 2,1 & 15,8 & 204,6 & 99,5 & 59,4 \\
\hline 300 & 46,9 & 5,2 & 56,6 & 26,3 & 8,3 & 1,8 & 15,4 & 188,8 & 129,5 & 64,1 \\
\hline $300 \mathrm{M}$ & 57,5 & 5,7 & 52,0 & 25,3 & 7,0 & 2,4 & 16,2 & 170,3 & 111,8 & 60,8 \\
\hline 600 & 46,8 & 5,4 & 56,6 & 23,2 & 7,1 & 1,6 & 10,5 & 180,7 & 109,1 & 57,4 \\
\hline $600 \mathrm{M}$ & 49,1 & 5,9 & 55,1 & 24,9 & 8,4 & 1,7 & 18,7 & 192,3 & 106,9 & 65,2 \\
\hline 900 & 51,4 & 5,7 & 44,4 & 18,7 & 7,8 & 2,0 & 15,3 & 180,3 & 100,0 & 57,3 \\
\hline $900 \mathrm{M}$ & 54,2 & 6,0 & 42,8 & 24,4 & 7,9 & 1,7 & 13,4 & 187,3 & 98,3 & 59,8 \\
\hline Média & 50,5 & 5,6 & 53,2 & 24,3 & 7,7 & 1,9 & 13,9 & 183,9 & $\overline{105,4}$ & 61,2 \\
\hline
\end{tabular}


A análise dos frutos está apresentada na Tabela 12. Em média, os teores de N, P, K, Ca, Mg e S foram de 47,3 $\mathrm{g} \mathrm{kg}^{-1} ; 6,3 \mathrm{~g} \mathrm{~kg}^{-1} ; 53,5 \mathrm{~g} \mathrm{~kg}^{-1} ; 4,3 \mathrm{~g} \mathrm{~kg}^{-1}$, $3,1 \mathrm{~g} \mathrm{~kg}^{-1}$ e $2,3 \mathrm{~g} \mathrm{~kg}^{-1}$, respectivamente. Para N, K, Ca e S, os teores encontrados no experimento foram superiores aos encontrados por Furlani et al. (1978) para a cultura da abobrinha, enquanto para $\mathrm{P}$ e $\mathrm{Mg}$ os teores encontrados foram inferiores aos dos autores citados. Essas diferenças ocorreram em função das cultivares utilizadas e de variáveis ambientais e nutricionais envolvidas nos dois trabalhos. Porém os resultados são importantes, pois dão indicativos dos totais exportados do solo em cada colheita. Assim, considerando-se a massa de material seco como $4 \%$ da matéria fresca, tem-se para cada tonelada de fruto produzido um consumo de $1,89 \mathrm{~kg}$ de $\mathrm{N} ; 0,25 \mathrm{~kg}$ de P; 2,34 $\mathrm{kg}$ de $\mathrm{K}$; $0,17 \mathrm{~kg}$ de Ca e $0,12 \mathrm{~kg}$ de $\mathrm{Mg}$ e $0,092 \mathrm{~kg}$ de $\mathrm{S}$.

Para os micronutrientes, os teores médios de B, Fe, Mn e Zn foram de $20,8 \mathrm{mg} \mathrm{kg}^{-1} ; 105,5 \mathrm{mg} \mathrm{kg}^{-1} ; 34,9 \mathrm{mg} \mathrm{kg}^{-1}$ e 64,8 $\mathrm{mg} \mathrm{kg}^{-1}$, respectivamente (Tabela 12). Dessa forma, o total de micronutrientes exportados por tonelada de fruto produzido foi de $0,83 \mathrm{~g}$ de $\mathrm{B} ; 4,22 \mathrm{~g}$ de Fe; $1,39 \mathrm{~g}$ de Mn e 2,59 $\mathrm{g}$ de $\mathrm{Zn}$.

Tabela 12. Teores de nutrientes nos frutos de abobrinha, cultivados com água carbonatada e cobertura plástica (M). Piracicaba. 2000.

\begin{tabular}{|c|c|c|c|c|c|c|c|c|c|c|}
\hline \multirow[t]{2}{*}{ Trat. } & $\mathrm{N}$ & $\mathrm{P}$ & $\mathrm{K}$ & $\mathrm{Ca}$ & $\mathrm{Mg}$ & $S$ & $\mathrm{~B}$ & $\mathrm{Fe}$ & $\mathrm{Mn}$ & $\mathrm{Zn}$ \\
\hline & \multicolumn{6}{|c|}{$\mathrm{g} \mathrm{kg}^{-1}$} & \multicolumn{4}{|c|}{$\mathrm{mg} \mathrm{kg}^{-1}$} \\
\hline$\overline{0}$ & 49,0 & 5,8 & 56,4 & 3,8 & 3,2 & 2,8 & 12,3 & 122,5 & 32,9 & 71,0 \\
\hline $0 \mathrm{M}$ & 59,5 & 6,8 & 50,5 & 4,2 & 2,6 & 2,1 & 24,0 & 88,4 & 34,1 & 62,2 \\
\hline 300 & 40,3 & 5,8 & 44,4 & 4,4 & 2,9 & 2,2 & 18,0 & 91,3 & 29,1 & 58,6 \\
\hline $300 \mathrm{M}$ & 42,8 & 6,3 & 45,9 & 4,9 & 2,6 & 2,3 & 16,2 & 103,4 & 30,6 & 58,0 \\
\hline 600 & 54,9 & 6,1 & 53,5 & 3,8 & 3,3 & 2,4 & 28,8 & 94,2 & 30,1 & 64,8 \\
\hline $600 \mathrm{M}$ & 40,3 & 4,5 & 52,0 & 4,1 & 3,1 & 2,0 & 22,9 & 86,6 & 40,1 & 58,3 \\
\hline 900 & 52,1 & 7,0 & 55,1 & 4,1 & 3,3 & 1,7 & 18,8 & 123,9 & 37,7 & 66,3 \\
\hline $900 \mathrm{M}$ & 39,2 & 7,7 & 70,4 & 5,3 & 3,9 & 3,1 & 25,1 & 133,4 & 44,4 & 78,9 \\
\hline Média & 47,3 & 6,3 & 53,5 & 4,3 & 3,1 & 2,3 & 20,8 & 105,5 & 34,9 & 64,8 \\
\hline
\end{tabular}


A seqüência de macronutrientes presentes nos frutos foi: $\mathrm{K}>\mathrm{N}>\mathrm{P}>\mathrm{Ca}>\mathrm{Mg}>\mathrm{S}$, enquanto a de micronutrientes foi $\mathrm{Fe}>\mathrm{Zn}>\mathrm{Mn}>\mathrm{B}$, semelhante aos resultados obtidos por Furlani et al. (1978), exceto para o teor de Ca que tinha sido superior ao de $\mathrm{P}$.

\subsection{Experimento II}

\subsubsection{Elementos meteorológicos}

Os dados meteorológicos, observados durante o experimento, revelaram temperaturas médias do ar na faixa ideal para o crescimento da cultura, a qual está entre $18{ }^{\circ} \mathrm{C}$ e $24^{\circ} \mathrm{C}$ (Lorenz \& Maynard, 1988) (Tabela 13). Dessa forma, foram propiciados bom desenvolvimento e boa uniformidade no stand para a cultura, quando comparada ao primeiro experimento (Figura 13).

Os termômetros de relva revelaram temperaturas máximas médias de $32,5^{\circ} \mathrm{C}$, para os tratamentos com mulch, e $29,2^{\circ} \mathrm{C}$, para os tratamentos com solo nu. Para as temperaturas mínimas, as médias foram $22,4^{\circ} \mathrm{C}$, para o primeiro caso, e $18,4^{\circ} \mathrm{C}$, para o segundo. As amplitudes médias calculadas foram semelhantes para os tratamentos com e sem cobertura plástica, sendo de $10,1^{\circ} \mathrm{C}$ e $10,8^{\circ} \mathrm{C}$, respectivamente (Figura 14).

Tabela 13 . Elementos climáticos na área durante o experimento em 2000, Piracicaba.

\begin{tabular}{|c|c|c|c|c|c|c|c|c|}
\hline \multirow[b]{2}{*}{ MÊS } & \multicolumn{2}{|c|}{$\begin{array}{l}\text { TEMP. MÉDIA } \\
\text { DO AR }\left({ }^{0} \mathrm{C}\right)\end{array}$} & \multirow{2}{*}{$\begin{array}{c}\text { TEMP. } \\
\text { MÉDIA DO } \\
\text { AR }\left({ }^{\circ} \mathrm{C}\right)\end{array}$} & \multirow[t]{2}{*}{$\begin{array}{l}\text { U.R. } \\
(\%)\end{array}$} & \multirow{2}{*}{$\begin{array}{c}\text { PREC. } \\
\text { TOTAL } \\
(\mathrm{mm})\end{array}$} & \multirow{2}{*}{$\begin{array}{c}\text { DIAS } \\
\text { COM } \\
\text { CHUVA }\end{array}$} & \multirow[t]{2}{*}{$\begin{array}{l}\text { EVAP. } \\
(\mathrm{mm})\end{array}$} & \multirow{2}{*}{$\begin{array}{c}\text { VEL. DO } \\
\text { VENTO } \\
\left(\mathrm{m} \mathrm{s}^{-1}\right)\end{array}$} \\
\hline & MÍN. & MÁX. & & & & & & \\
\hline SET & 15,1 & 27,2 & 21,1 & 73,0 & 91,2 & 9 & 136,5 & 2,5 \\
\hline OUT & 17,9 & 32,1 & 25,0 & 68,5 & 104,4 & 6 & 168,9 & 2,2 \\
\hline NOV & 17,7 & 29,8 & 23,7 & 77,3 & 264,4 & 9 & 137,3 & 2,1 \\
\hline DEZ & 19,0 & 29,8 & 24,4 & 81,0 & 196,2 & 16 & 177,3 & 1,9 \\
\hline
\end{tabular}



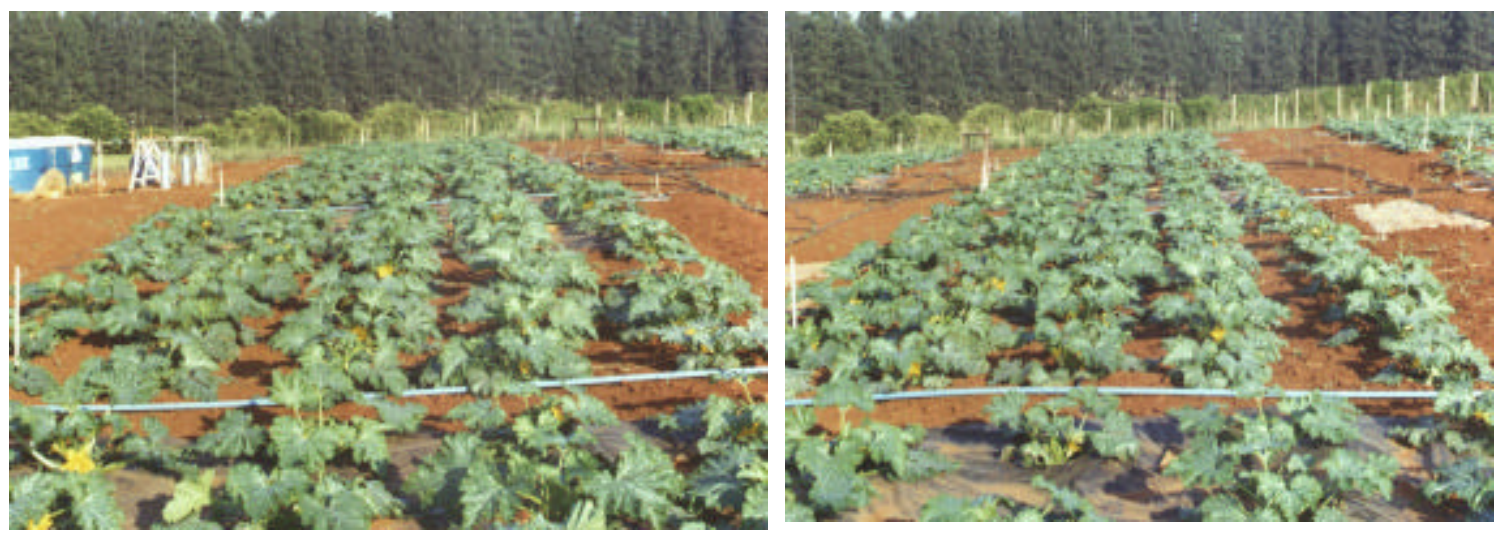

Figura 13 - Vista da área experimental em plena fase de colheita de abobrinha (foto à esquerda, referente ao bloco I; foto à direita, referente ao bloco II). Piracicaba, 2000.



Figura 14 - Valores diários de temperaturas de relva máxima e mínima observadas, durante o período experimental.

As temperaturas mais elevadas do ar propiciaram uma antecipação do ciclo reprodutivo, que se iniciou aos 29 DAT, em comparação ao primeiro experimento, 
cujo início ocorreu aos 41 DAT. Porém não foi observada antecipação do ciclo em função dos tratamentos. Contrariamente, Mormeneo \& Cantamutto (1999) observaram antecipação nos estádios de desenvolvimento, com o uso do mulch.

\subsubsection{Manejo da irrigação}

O manejo de água foi realizado de forma a proporcionar às plantas um adequado suprimento hídrico, procurando-se deixar o potencial mátrico do solo sempre próximo à capacidade de campo. A lâmina de água, aplicada na cultura entre 22 de setembro e 5 de dezembro, ou dos 2 aos 76 DAT, foi cerca de 129,6 mm. Nesse período, o total de chuvas foi de $68,8 \mathrm{~mm}$, com maior incidência entre os 52 e 71 DAT, representando $53,9 \%$ do total precipitado. O total evaporado pelo tanque Classe A foi 374,2 mm. Da germinação até a última colheita, transcorreram 89 dias.

Os potenciais mátricos da água no solo $(-\mathrm{kPa})$ foram medidos 24 horas após a irrigação (Figura 15). As leituras menores do potencial ocorreram em virtude das precipitações. As médias dos potenciais para todo o ciclo foram de $-10,7 \mathrm{kPa}$ e $-7,9 \mathrm{kPa}$ para a profundidade de $10 \mathrm{~cm}$ em solo nu e solo coberto, respectivamente. Ficaram evidentes, dessa forma, uma boa manutenção da umidade nas camadas superficiais do solo, para todos os tratamentos, e um maior conteúdo de umidade nos tratamentos com o uso de mulch, devido à redução no processo de evaporação do solo. Vários autores observaram resultados semelhantes, quando se utilizou a cobertura plástica no solo (Makishima \& Miranda, 1992; Sampaio, 1996; Sandres, 1996).

A Figura 16 apresenta os valores de precipitação e da evaporação do tanque classe A, ocorridos dos 12 aos 73 dias após o transplantio.

Os aumentos abruptos dos potenciais de água do solo observados na Figura 15, podem ser atribuídos às precipitações que ocorreram no período (Figura 16), e que se caracterizaram pela alta intensidade e pela curta duração. 


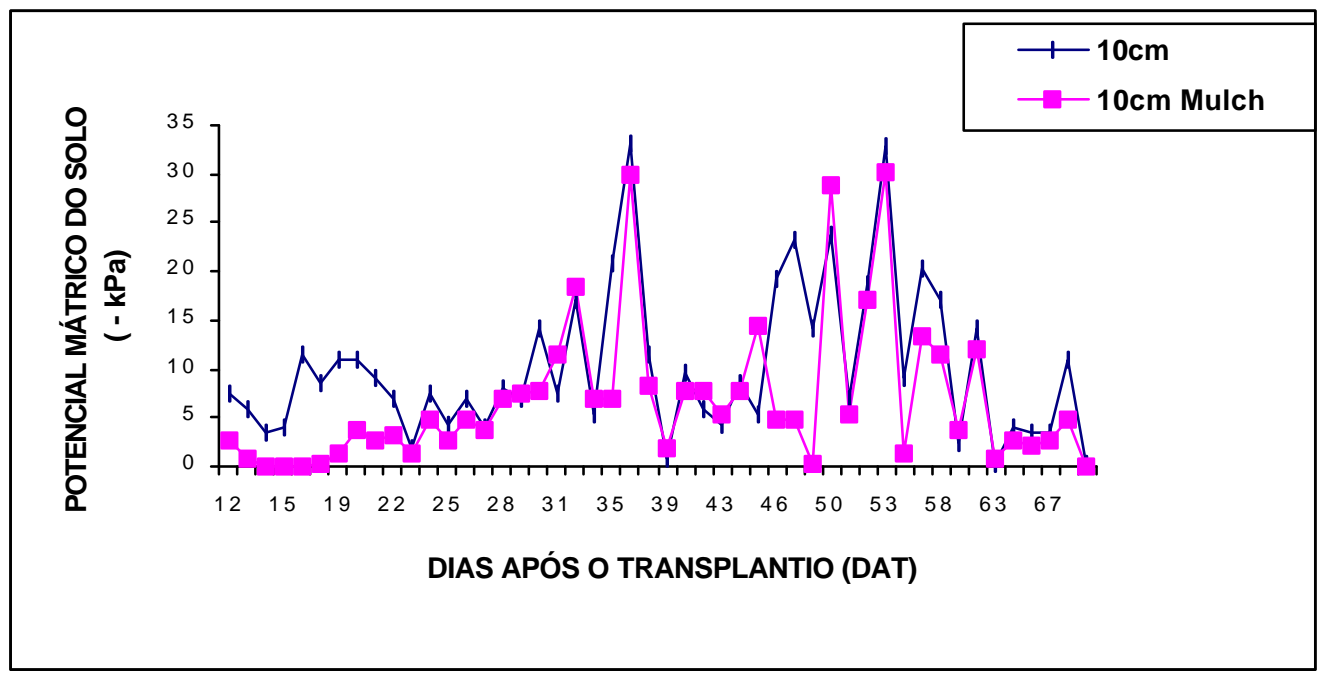

Figura 15 - Leituras dos tensiômetros $(-\mathrm{kPa})$ a $10 \mathrm{~cm}$ de profundidade nas parcelas sob cobertura plástica (Mulch) ou sob solo nu durante o período experimental.



Figura 16 - Leituras de precipitação $(\mathrm{mm})$ e evaporação $(\mathrm{mm})$ do tanque classe A ocorridas durante o período experimental. 


\subsubsection{Uso da água carbonatada}

A Figura 17 apresenta os valores de $\mathrm{pH}$ e $\mathrm{CE}$ da água da fonte e da coletada junto aos gotejadores, nos diferentes tratamentos, no momento da irrigação. As médias do pH para a água da fonte e para os tratamentos 0, 300, 600 e 900 foram 7,8; 7,$5 ; 6,9 ; 5,8$ e 5,6, respectivamente. De forma semelhante aos resultados obtidos no primeiro experimento, a água dos tratamentos que utilizaram o $\mathrm{CO}_{2}$ apresentou uma redução substancial no pH, em virtude da formação de ácido carbônico.

As diferenças nas médias de leituras do $\mathrm{pH}$, observadas entre a água da fonte e o tratamento testemunha, podem ser explicadas pelo uso da uréia como fonte de $\mathrm{N}$, durante a fertirrigação, a qual também reduz o pH da água (Pavan \& Miyazawa, 1996). Não foram feitas leituras de $\mathrm{pH}$ do solo durante a aplicação da água carbonatada, porém acredita-se que tenha ocorrido numa redução, sobretudo, nas faixas de solo próximas às linhas de gotejadores.

Os valores de condutividade elétrica entre a água da fonte e os tratamentos foram semelhantes exceto aos 27, 29, 51 e 62 DAT, estando essa diferença associada à fertirrigação (Figura 17). A água da fonte apresentou CE médio de $0,32 \mathrm{dS} \mathrm{m}^{-1}$, ao longo do experimento, enquanto, para os tratamentos 0, 300, 600 e 900, as CE médias foram de $0,73 \mathrm{dS} \mathrm{m} \mathrm{m}^{-1} ; 0,68 \mathrm{dS} \mathrm{m} \mathrm{m}^{-1} ; 0,86 \mathrm{dS} \mathrm{m} \mathrm{m}^{-1}$ e $0,86 \mathrm{dS} \mathrm{m} \mathrm{m}^{-1}$, respectivamente.
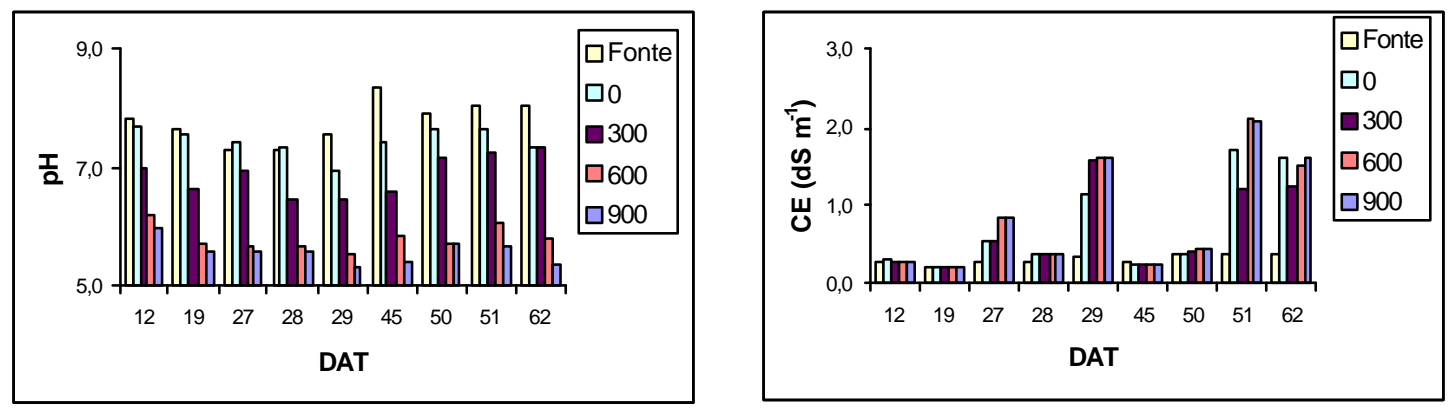

Figura 17 - $\mathrm{pH}$ e $\mathrm{CE}\left(\mathrm{dS} \mathrm{m}^{-1}\right)$ da água coletada na fonte e nos gotejadores nas diferentes doses de $\mathrm{CO}_{2}$ no experimento. 
Novero et al. (1991) observaram redução no pH do solo durante a irrigação com água carbonatada. Segundo Storlie \& Heckman (1996b), a adição de $\mathrm{CO}_{2}$ pode causar uma redução momentânea no $\mathrm{pH}$ do solo, disponibilizando alguns elementos para a planta. Entretanto, se o solo for ácido, pode haver uma maior disponibilidade de alumínio, causando toxidez e/ou indisponibilização de elementos essenciais para a planta. Moore (1990) comenta que o dióxido de carbono possui comportamento de quelato, podendo associar-se a elementos do solo como cálcio, cobre, ferro, magnésio, manganês e cobalto, formando complexos facilmente carreáveis até as raízes das plantas para absorção.

A Figura 18 apresenta a modificação nos teores de $\mathrm{CO}_{2}$ aéreo, com o uso da água carbonatada.


Figura 18 - Teores de $\mathrm{CO}_{2}$ no ar $\left(\mathrm{mg} \mathrm{L}^{-1}\right)$ captados a $15 \mathrm{~cm}$ do solo nos diferentes tratamentos nos dias 11/outubro, e 4, 9 e 10/novembro de 2000, antes, durante e 5, 20 e 40 minutos após a irrigação com água carbonatada.

Quanto à modificação nos teores de $\mathrm{CO}_{2}$ do ar com o uso de água carbonatada, observa-se que os valores se elevaram durante a irrigação com água 
carbonatada e após 5 minutos do término dela; entretanto isso não foi generalizado, ou seja, esse fato não foi verificado em todas as parcelas, possivelmente devido à ação do vento durante as leituras.

Storlie \& Heckman (1996b) verificaram, em uma série de outros experimentos, onde se mediu o perfil de $\mathrm{CO}_{2}$, que pouca ou nenhuma elevação nos

teores de $\mathrm{CO}_{2}$ aéreo ocorreu, e atribuíram isso à velocidade do vento sobre o experimento durante as medidas. De fato, Hartz et al. (1991) comentam que a aplicação de $\mathrm{CO}_{2}$, via aérea, em experimento sob túneis, era mantida com extrema dificuldade, quando a velocidade do vento fora deles excedia $5 \mathrm{~m} \mathrm{~s}^{-1}$.

\subsubsection{Análise de crescimento}

\subsubsection{1 Área foliar aos $64 \mathrm{DAT}$}

A análise de variância revelou efeito significativo da interação entre as doses de $\mathrm{CO}_{2}$ e a cobertura plástica sobre a área foliar de abobrinha, aos 64 DAT.

Para o solo coberto, não foi possível um ajuste de modelo com significado biológico, sendo a média geral da área foliar de $16.923 \mathrm{~cm}^{2}$. Para o solo nu, foi obtido um modelo linear em função das doses de $\mathrm{CO}_{2}$ para a área foliar, indicando uma redução dessa, com o aumento das doses de $\mathrm{CO}_{2}$ (Figura 19). Contrariamente, Mauney \& Hendrix (1988) e Guri et al. (1999) obtiveram aumento na área foliar com o uso de água carbonatada em algodão e pimentão, respectivamente. Entretanto os autores trabalharam somente com uma dose. Storlie \& Heckman (1996b) sugerem que não há consenso sobre os efeitos quantitativos do gás carbônico no desenvolvimento das plantas, devido às diferenças entre as espécies e porque o efeito dos fatores ambientais pode limitar a resposta da cultura. 


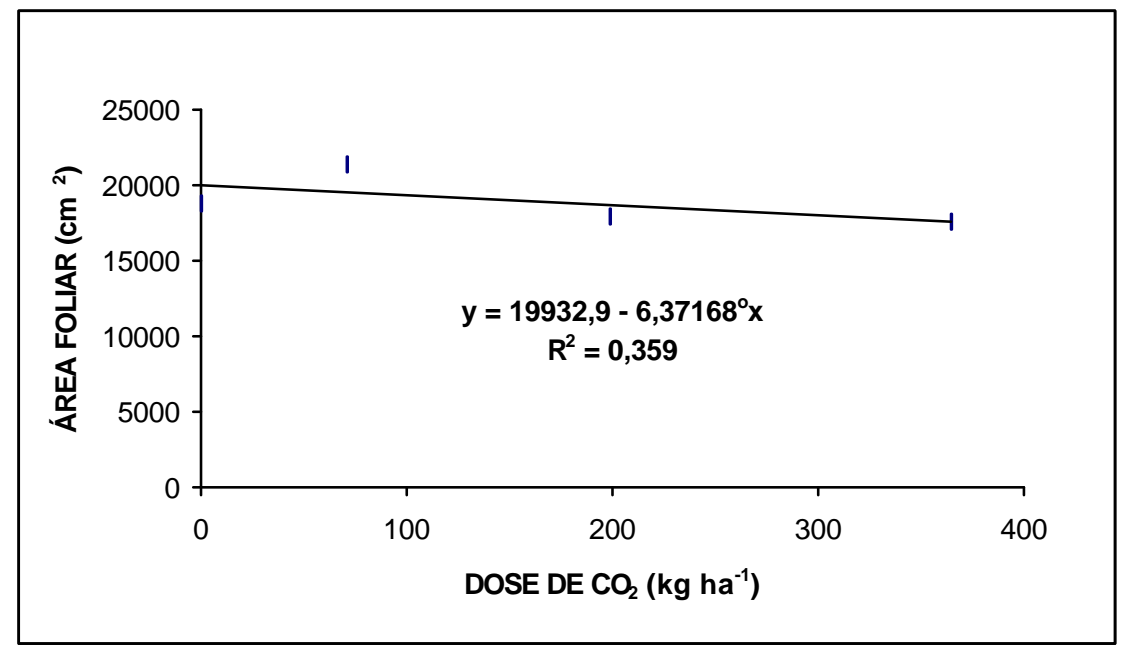

${ }^{\circ}$, significativo a $10 \%$ de probabilidade pelo teste $\mathrm{t}$

Figura 19 - Área foliar $\left(\mathrm{cm}^{2}\right)$ de abobrinha e sua equação de regressão, em função das doses de $\mathrm{CO}_{2}$ aplicadas via água de irrigação, para solo nu. Piracicaba, SP, 2000 .

\subsubsection{Massa de material seco aos 64 DAT}

A massa de material seco da parte aérea (MMSPA) e das raízes (MMSR) foi influenciada significativamente apenas pelas doses de $\mathrm{CO}_{2}$, sendo ajustados modelos quadráticos para ambas as variáveis.

A equação de regressão para MMSPA, em função das doses de $\mathrm{CO}_{2}$, apresenta ponto de valor máximo de $208,4 \mathrm{~g}$, com a adição de $177,4 \mathrm{~kg} \mathrm{ha}^{-1}$ de gás carbônico na água (Figura 20). 


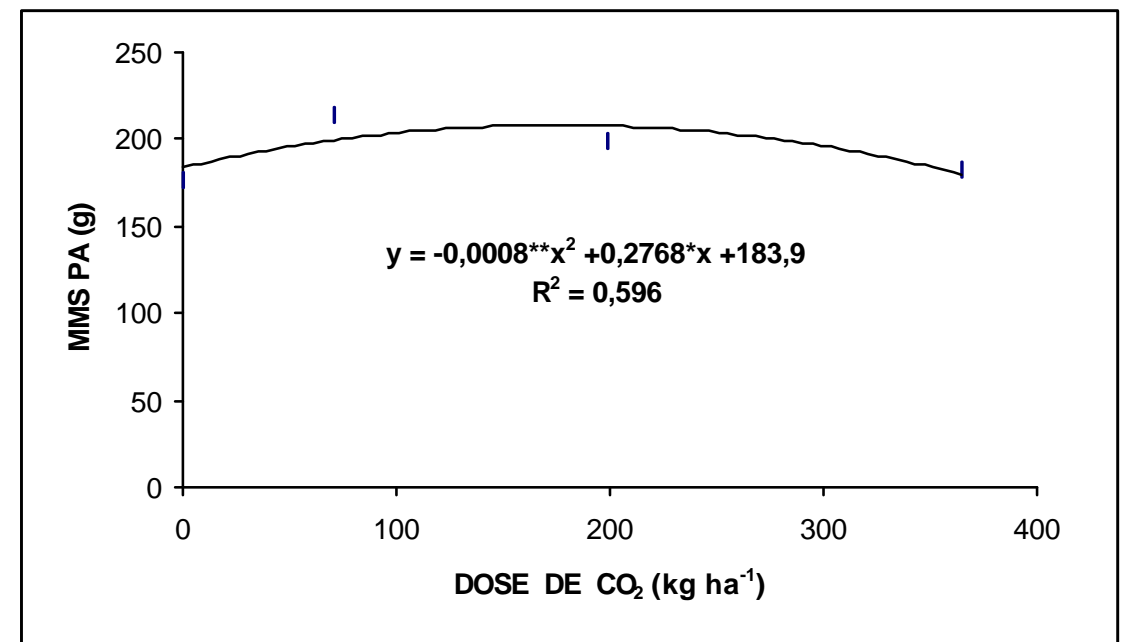

*,**, significativos a 5 e $1 \%$ de probabilidade, respectivamente, pelo teste $\mathrm{t}$

Figura 20 - Massa de material seco da parte aérea (MMSPA) de abobrinha em (g) e sua equação de regressão, em função das doses de $\mathrm{CO}_{2}$ aplicadas via água de irrigação. Piracicaba, SP, 2000.

Vários autores reportaram que o $\mathrm{CO}_{2}$ estimula a produção de biomassa (Mauney \& Hendrix, 1988; Vessey et. al., 1990; Hartz et. al., 1991; Idso \& Idso,1994 ). Storlie \& Heckman (1996b) sugerem que o uso da água carbonatada estimula o crescimento da planta, quer pelo fornecimento de carbono diretamente às raízes, que estimula o seu desenvolvimento, quer pela melhora das condições nutricionais da planta, ou por ambos os motivos; porém vários são os fatores que podem interferir no balanço positivo do carbono, tais como: irrigação, adubação, pragas, doenças e fatores ambientais.

No experimento, o suprimento hídrico e de nutrientes adequados para a cultura ficou evidenciado pelo manejo da irrigação e da adubação utilizada. A literatura cita que a absorção de carbono pelas raízes da planta ocorre, porém, em pequenas proporções, chegando no máximo a $5 \%$ do total requerido pela cultura (Arteca et. al., 1979; Baron \& Gorski, 1986). O que parece mais evidente é o estímulo que a água carbonatada causa na absorção de nutrientes e de carbono. Segundo Moore (1990), o $\mathrm{CO}_{2}$ reage com os cátions da solução do solo, produzindo bicarbonatos, os quais são 
absorvidos pelas plantas. Os resultados estão de acordo com Idso \& Idso (1994), que apresentaram uma ampla revisão sobre a aplicação de $\mathrm{CO}_{2}$; no geral, os trabalhos indicam elevação na produção de biomassa com o uso do gás.

A Figura 21 apresenta a equação de regressão para MMSR, em função das doses de $\mathrm{CO}_{2}$. O ponto de valor máximo da variável dependente foi 4,18 g, obtido com a adição de $139,5 \mathrm{~kg} \mathrm{ha}^{-1}$ de gás carbônico na água.

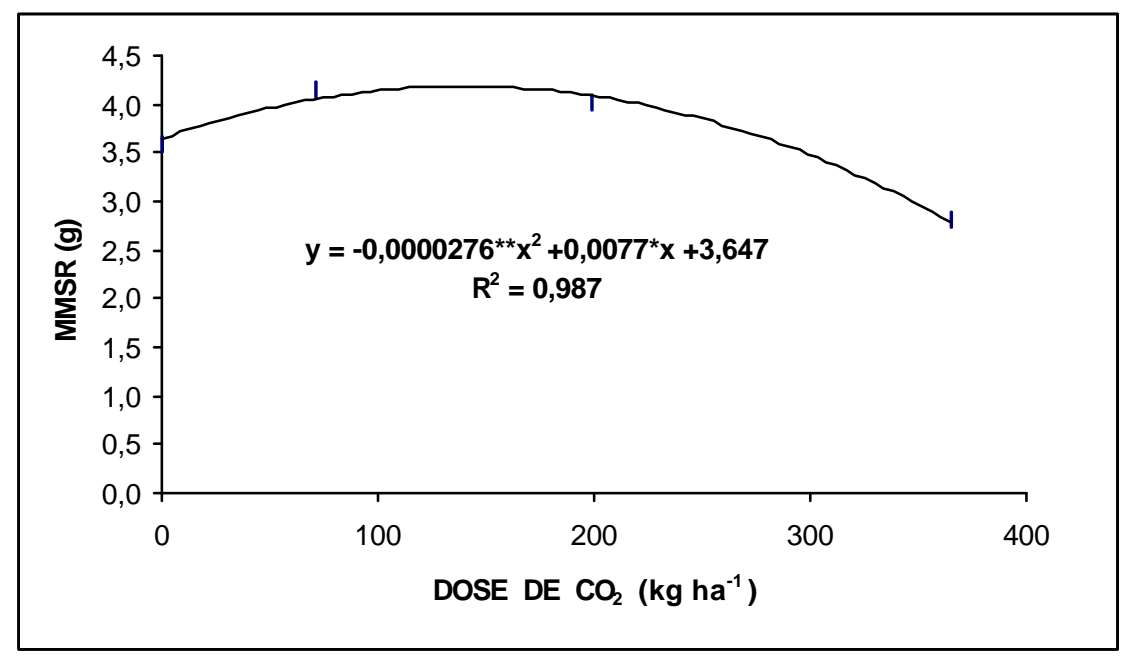

$*$, **, significativos a 5 e $1 \%$ de probabilidade, respectivamente, pelo teste $\mathrm{t}$

Figura 21 - Massa de material seco da raiz (MMSR) de abobrinha em (g), em função das doses de $\mathrm{CO}_{2}$ aplicadas via água de irrigação. Piracicaba, SP, 2000.

De posse dos resultados, calculou-se a razão entre as raízes e a parte aérea, sendo possível ajustar um modelo quadrático para as doses de $\mathrm{CO}_{2}$, aplicadas via água (Figura 22). A maior razão foi de $2 \%$, obtida com a dose de $83,3 \mathrm{~kg}^{-1}$ de $\mathrm{CO}_{2}$.

A literatura é contraditória quanto a esse aspecto, pois alguns autores sugerem que o uso de $\mathrm{CO}_{2}$ estimula a parte aérea da planta, alterando a razão raízes/parte aérea (Sionit et al., 1981; Vessey et al., 1990). Mudrik et al. (1997) sugerem aumento na razão raízes/parte aérea por alterações no balanço hormonal, induzido pelas altas concentrações de $\mathrm{CO}_{2}$. Contrariamente, Gifford (1979) não observou qualquer efeito na razão (raízes/parte aérea) em ambiente rico em $\mathrm{CO}_{2}$. Chaudhuri et al. (1990) observaram 
aumento na massa de material das raízes, sem, entretanto, observarem efeito na razão raízes/parte aérea. Aparentemente, experimentos com aplicação de $\mathrm{CO}_{2}$, mas com alguma redução na disponibilidade hídrica ou nutricional, promovem alterações na razão raízes/parte aérea.

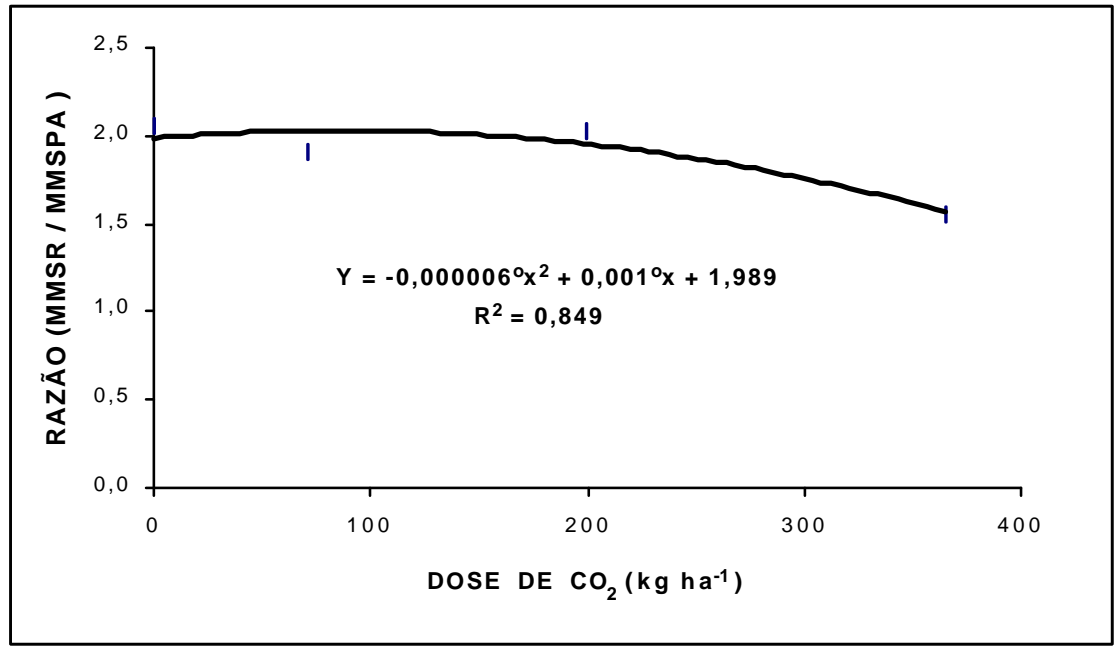

o, significativo a $10 \%$ de probabilidade pelo teste $\mathrm{t}$

Figura 22 - Razão da massa de material seco da raiz e da parte aérea (MMSR/MMSPA) de abobrinha, em função das doses de $\mathrm{CO}_{2}$ aplicadas via água de irrigação. Piracicaba, SP, 2000.

\subsubsection{Análise da solução do solo.}

Os teores médios de macronutrientes minerais, o pH e a $\mathrm{CE}$ da solução do solo coletada ao longo do ciclo da cultura são apresentados na Figura 23. Em geral, a solução do solo apresentou teores de nutrientes inferiores aos encontrados na solução do solo do primeiro experimento. Possivelmente, pela maior utilização de nutrientes pela cultura neste experimento, constatados pela maior produção de massa de material seco e de frutos. $\mathrm{O}$ pH apresentou uma ligeira elevação com a adição de $\mathrm{CO}_{2}$, tal como ocorrido no primeiro experimento. 



Figura 23 - Teores de médios dos macronutrientes minerais $\left(\mathrm{mg} \mathrm{L}^{-1}\right), \mathrm{pH}$ e $\mathrm{CE}\left(\mathrm{dS} \mathrm{m} \mathrm{m}^{-1}\right)$ da solução do solo em função dos tratamentos, em diferentes dias após o tansplante (DAT). Piracicaba, 2000.

\subsubsection{Absorção de nutrientes}

As concentrações de nutrientes variam com o tempo e nas diferentes partes da planta. Porém é nas folhas que ocorre a maioria dos processos fisiológicos para a produção. Dessa forma, a avaliação do seu conteúdo em nutrientes reflete o estado nutricional da planta (Epstein, 1975; Malavolta et al, 1989). A Figura 24 apresenta os teores de N, P, K e Ca, encontrados nas folhas de abobrinha, aos 17, 28, 64 e 76 DAT .

Aos 17 DAT, pouco antes do florescimento, o qual ocorreu aos 22 DAT, os teores de $\mathrm{N}$ e $\mathrm{K}$ nas folhas eram semelhantes em todos os tratamentos, com média geral de $56,19 \mathrm{~g} \mathrm{~kg}^{-1}$ e 52,98 $\mathrm{g} \mathrm{kg}^{-1}$, respectivamente. O teor de Ca foi inferior a esses nutrientes e superior ao do fósforo. A média do teor de fósforo, considerando-se todos os tratamentos, foi de $7,1 \mathrm{~g} \mathrm{~kg}^{-1}$. Esse valor encontra-se dentro dos limites críticos para a abobrinha, segundo Buwalda \& Freeman (1988). Os autores comentam que a deficiência de fósforo nesse período pode afetar a taxa de crescimento e a produção. No geral, os teores nas folhas, para os diferentes elementos, encontravam-se dentro ou acima dos limites recomendados por Mills \& Jones Junior (1996) para a cultura da abobrinha, que são de 40 a $60 \mathrm{~g} \mathrm{~kg}^{-1}$ de $\mathrm{N} ; 3$ a $5 \mathrm{~g} \mathrm{~kg}^{-1}$ para P; 30 a $50 \mathrm{~g} \mathrm{~kg}^{-1}$ para $\mathrm{K} \mathrm{e}$ 
12 a $25 \mathrm{~g} \mathrm{~kg}^{-1}$ para Ca. Os resultados indicaram que a cultura não apresentava qualquer problema de deficiência nutricional.
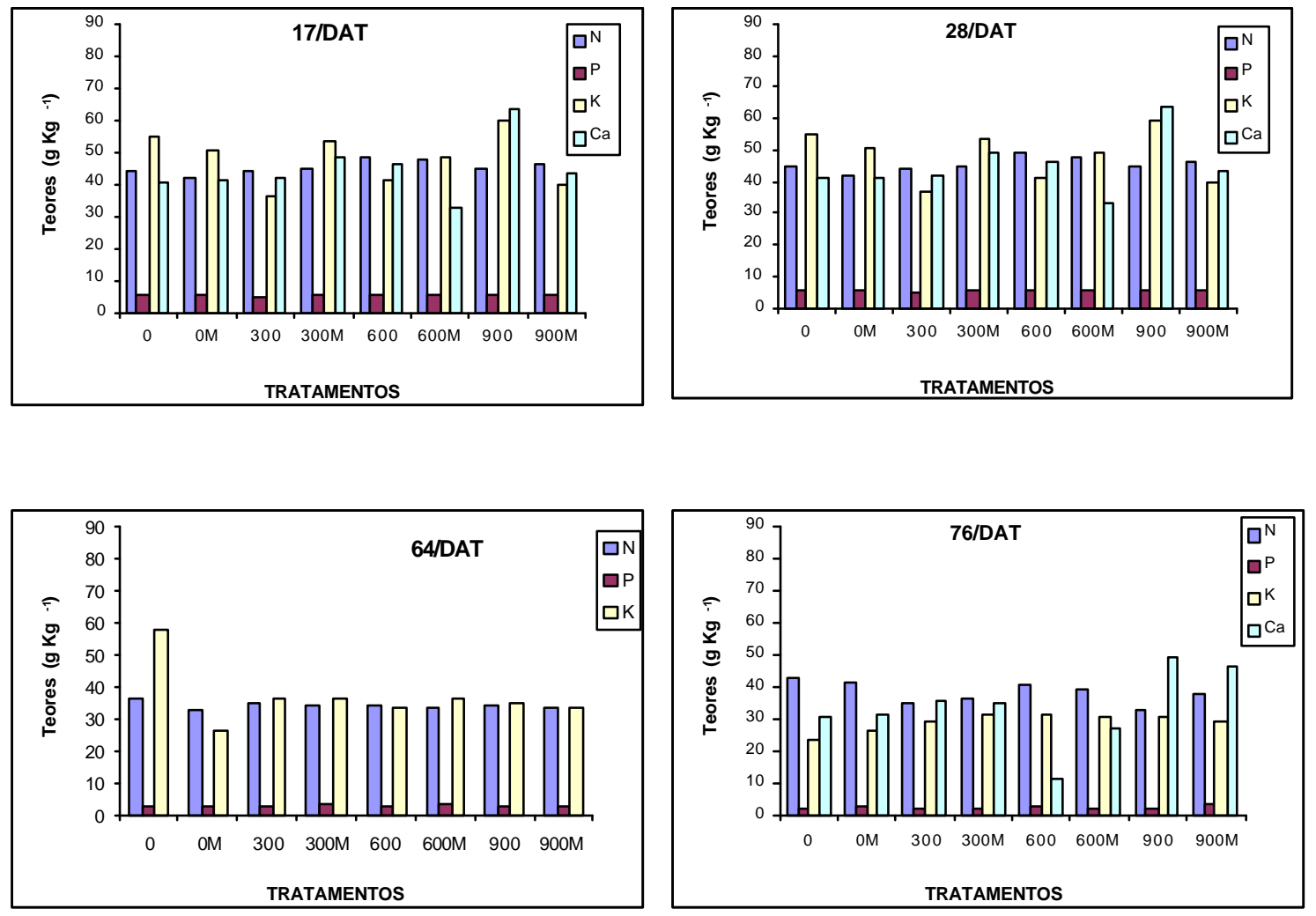

Figura 24 - Teores de N, P, K e Ca observados em folhas de abobrinha cultivada com água carbonatada e cobertura plástica (M) aos 17, 28, 64 e 76 DAT.

Aos 28 DAT, houve uma elevação nos teores de cálcio, com média de $44,9 \mathrm{~g} \mathrm{~kg}^{-1}$, assemelhando-se às quantidades de $\mathrm{N}$ e $\mathrm{K}$, que sofreram uma redução e mostraram médias de $45,4 \mathrm{~g} \mathrm{~kg}^{-1}$ e $48,2 \mathrm{~g} \mathrm{~kg}^{-1}$, respectivamente.

Aos 64 DAT, no tratamento testemunha a quantidade de $\mathrm{K}$ superou aparentemente o teor dos demais nutrientes, mantendo a tendência que já se mostrava nas coletas anteriores. Nesse período, a análise do teor de cálcio nas folhas apresentou problemas e não foi mostrada na Figura 24. Ressalta-se, entretanto, que Solis et al. (1988c) encontraram elevação no teor de cálcio nas folhas, com a idade, da planta de 
pepino (Cucumis sativus L.) cultivado em condições de campo. Os autores observaram que o acúmulo da $\mathrm{Ca}$ obedeceu à curva de massa do material seco da parte aérea.

No período entre 66 e 76 DAT, conforme relatado anteriormente, ocorreram precipitações excessivas, o que propiciou uma queda na produção e uma depreciação visual na cultura. Assim, com os valores coletados aos 76 DAT, optou-se por fazer uma análise dos nutrientes contidos em toda a parte aérea, exceto nos frutos. A idéia é que esses nutrientes podem ser exportados, caso a cultura seja removida para fora da área de cultivo, ou reaproveitados, caso os restos culturais sejam incorporados ao solo ao término do ciclo.

A Tabela 14 apresenta o conteúdo de alguns nutrientes na planta de abobrinha, aos 76 DAT. No geral, as doses de $\mathrm{CO}_{2}$ levaram à maior absorção de nutrientes pela cultura.

Tabela 14. Quantidade de minerais na parte aérea (caule e folhas) de abobrinha aos 76 DAT cultivados com água carbonatada e cobertura plástica (M).

\begin{tabular}{|c|c|c|c|c|c|c|c|c|c|c|}
\hline \multirow[t]{2}{*}{ Trat. } & $\mathrm{N}$ & $\mathrm{P}$ & $\mathrm{K}$ & $\mathrm{Ca}$ & $\mathrm{Mg}$ & \multirow[t]{2}{*}{ S } & $\mathrm{B}$ & $\mathrm{Fe}$ & $\mathrm{Mn}$ & $\mathrm{Zn}$ \\
\hline & \multicolumn{5}{|c|}{ g planta ${ }^{-1}$} & & \multicolumn{4}{|c|}{ mg planta $^{-1}$} \\
\hline 0 & 7,61 & 0,47 & 6,58 & 5,70 & 1,52 & 0,58 & 6,77 & 783,13 & 23,07 & 7,24 \\
\hline $0 \mathrm{M}$ & 6,56 & 0,51 & 5,93 & 5,43 & 1,46 & 0,53 & 5,89 & 359,89 & 30,61 & 7,53 \\
\hline 300 & 9,08 & 0,72 & 9,13 & 10,83 & 2,94 & 0,65 & 9,46 & 1036,90 & 46,58 & 11,76 \\
\hline $300 \mathrm{M}$ & 7,18 & 0,61 & 7,81 & 8,72 & 2,18 & 0,61 & 6,91 & 613,90 & 27,59 & 7,68 \\
\hline 600 & 8,18 & 0,64 & 8,66 & 4,38 & 2,08 & 0,72 & 8,67 & 861,13 & 31,21 & 8,91 \\
\hline $600 \mathrm{M}$ & 7,70 & 0,59 & 7,81 & 5,73 & 2,07 & 0,69 & 8,42 & 427,55 & 23,84 & 8,55 \\
\hline 900 & 8,10 & 0,56 & 9,13 & 10,32 & 2,52 & 0,82 & 11,47 & 936,96 & 51,96 & 8,87 \\
\hline $900 \mathrm{M}$ & 7,80 & 0,72 & 8,06 & 8,95 & 3,57 & 0,74 & 7,44 & 494,25 & 28,30 & 8,92 \\
\hline Média & 7,78 & 0,60 & 7,89 & 7,51 & 2,29 & 0,67 & 8,13 & 689,21 & 32,90 & 8,68 \\
\hline
\end{tabular}

Dentre os nutrientes analisados, o $\mathrm{P}$ apresentou resposta apenas para $\mathrm{o}$ fator cobertura, sendo observada uma média geral de 0,596 e 0,616 $\mathrm{g} \mathrm{planta}^{-1}$ para as plantas cultivadas em solo nu e sob cobertura plástica, respectivamente. Os conteúdos 
de $\mathrm{Ca}, \mathrm{Zn}, \mathrm{K}$ e $\mathrm{B}$ foram significativos para o fator dose, enquanto a maioria dos nutrientes ( $\mathrm{Mg}, \mathrm{S}, \mathrm{Mn}, \mathrm{Fe}$ e $\mathrm{Cu}$ ) se mostraram significativos, no nível de 5\% de probabilidade pelo teste F, para a interação entre dose e cobertura.

A Tabela 15 apresenta as equações de regressão de $\mathrm{Fe}$ e $\mathrm{Cu}$ para abobrinha cultivada em solo nu, enquanto a Tabela 16, equações de regressão de $\mathrm{Fe}$ e $\mathrm{Cu}$ para abobrinha cultivada em solo com cobertura plástica. A literatura aponta dois mecanismos possíveis para o aumento na absorção de nutrientes. O primeiro considera que a diminuição do $\mathrm{pH}$ do solo, causada pelo $\mathrm{CO}_{2}$, disponibilizaria certos nutrientes para a planta. O outro seria o prolongamento da vida útil das raízes, que teria como conseqüência maior possibilidade de absorção de nutrientes. Poderia haver, ainda, a combinação dos dois processos, levando a uma maior absorção de nutrientes pela cultura. Moore (1990) comenta que o dióxido de carbono possui comportamento de quelato, podendo associar-se a elementos do solo, formando complexos facilmente carreáveis até as raízes das plantas para absorção.

Tabela 15. Equações de regressão relacionando o conteúdo de $\mathrm{Fe}$ e $\mathrm{Cu}$ em abobrinha com as doses de $\mathrm{CO}_{2}(\mathrm{X})$ em solo nu.

\begin{tabular}{cccc}
\hline Variáveis & \multicolumn{1}{c}{ Equações de regressão } & $\mathrm{R}^{2}$ \\
\hline $\mathrm{Fe}$ & $\mathrm{Ye}=$ & $2,57546+0,009659 * \mathrm{X}-0,0000243 * \mathrm{X}^{2}$ & 0,413 \\
$\mathrm{Cu}$ & $\mathrm{Ye}=$ & $7,426449+0,0105158 * * \mathrm{X}$ & 0,595 \\
\hline$*, * *$, significativos a 5 e 1\% de probabilidade, respectivamente, pelo teste $\mathrm{t}$ &
\end{tabular}

Tabela 16. Equações de regressão relacionando o conteúdo de $\mathrm{Fe}$ e $\mathrm{Cu}$ em abobrinha com as doses de $\mathrm{CO}_{2}(\mathrm{X})$ em solo com cobertura plástica.

\begin{tabular}{lcc}
\hline Variáveis & Equações de regressão & $\mathrm{R}^{2}$ \\
\hline $\mathrm{Fe}$ & $\mathrm{Ye}=2,12889+0,0014295^{\circ} \mathrm{X}$ & 0,395 \\
$\mathrm{Cu}$ & $\mathrm{Ye}=5,78641+0,022199 * \mathrm{X}-0,000048175^{*} \mathrm{X}^{2}$ & 0,522 \\
\hline${ }^{\circ},{ }^{* *}$, significativos a 10,5 e $1 \%$ de probabilidade, respectivamente, pelo teste t &
\end{tabular}


Esses resultados são coerentes com aqueles apresentados por outros autores que utilizaram água carbonatada. Arteca et al. (1979) observaram elevação nos teores de $\mathrm{Ca}$ e $\mathrm{Mg}$ em batata. Em vários trabalhos, os nutrientes $\mathrm{Zn}$ e $\mathrm{Mn}$ têm apresentado maiores concentrações nos tratamentos com o uso de água carbonatada em diversas culturas (Mauney \& Hendrix, 1988; D’Andria et al., 1990; Novero et al., 1991). Novero et al. (1991) observaram elevação significativa nos teores de Zn, nos tratamentos com aplicação de água carbonata e uso do mulch na cultura do tomateiro. Embora não significativa, os teores de $\mathrm{P}, \mathrm{K}, \mathrm{Ca}, \mathrm{Mg}, \mathrm{Fe}, \mathrm{Mn}, \mathrm{Cu}$ e $\mathrm{B}$ apresentaram uma aparente elevação com o uso da água carbonatada.

\subsubsection{Avaliação dos teores de nutrientes nos frutos}

Os teores dos nutrientes do fruto foram avaliados em duas épocas distintas, aos 30 e 64 DAT, sendo apresentados nas Tabelas 17 e 18, respectivamente.

Tabela 17. Teores de nutrientes contidos em frutos de abobrinha cultivada com água carbonatada e cobertura plástica (M) determinado aos 30 DAT.

\begin{tabular}{|c|c|c|c|c|c|c|c|c|c|c|}
\hline \multirow[t]{2}{*}{ Trat. } & $\mathrm{N}$ & $\mathrm{P}$ & $\mathrm{K}$ & $\mathrm{Ca}$ & $\mathrm{Mg}$ & $S$ & $\bar{B}$ & $\mathrm{Fe}$ & $\mathrm{Mn}$ & $\mathrm{Zn}$ \\
\hline & \multicolumn{4}{|c|}{$\mathrm{g} \mathrm{kg}^{-1}$} & & & \multicolumn{4}{|c|}{$\mathrm{mg} \mathrm{kg}^{-1}$} \\
\hline 0 & 49,6 & 10,6 & 71,9 & 5,2 & 3,7 & 2,6 & 33,7 & 164,6 & 35,0 & 68,5 \\
\hline $0 \mathrm{M}$ & 59,6 & 9,4 & 65,8 & 5,0 & 3,3 & 2,0 & 30,9 & 177,6 & 36,2 & 63,2 \\
\hline 300 & 54,0 & 9,2 & 73,4 & 3,3 & 9,4 & 2,4 & 18,2 & 161,4 & 38,4 & 58,9 \\
\hline $300 \mathrm{M}$ & 55,6 & 9,1 & 70,4 & 5,2 & 10,9 & 2,8 & 34,6 & 144,0 & 35,0 & 67,1 \\
\hline 600 & 58,2 & 10,0 & 79,6 & 7,2 & 10,2 & 3,1 & 38,2 & 215,9 & 48,6 & 71,5 \\
\hline $600 \mathrm{M}$ & 56,0 & 9,3 & 73,4 & 5,7 & 3,4 & 2,9 & 59,8 & 145,8 & 31,8 & 56,4 \\
\hline 900 & 55,3 & 7,6 & 70,4 & 5,5 & 3,6 & 2,5 & 55,0 & 144,2 & 36,9 & 57,3 \\
\hline $900 \mathrm{M}$ & 51,5 & 9,9 & 76,5 & 6,2 & 3,6 & 2,7 & 40,0 & 129,6 & 32,3 & 63,7 \\
\hline Média & 55,0 & 9,4 & 72,7 & 5,4 & 6,0 & 2,6 & 38,8 & 160,4 & 36,8 & 63,3 \\
\hline
\end{tabular}


Aos 30 DAT, o teor de $\mathrm{K}$ nos frutos apresentou maior valor, com média de 72,7 $\mathrm{g} \mathrm{kg}^{-1}$, seguido por N, P, Mg, Ca e S (Tabela 17).

Aos 64 DAT, o teor de $\mathrm{K}$ nos frutos apresentou também maior valor, porém caiu de 72,7 $\mathrm{g} \mathrm{kg}^{-1}$, na análise anterior, para 48,0 $\mathrm{g} \mathrm{kg}^{-1}$ nesta análise (Tabela 18). Essa tendência de queda foi seguida por todos os nutrientes analisados. Isso leva a crer que os frutos das primeiras colheitas são mais ricos em nutrientes.

Trabalhos sobre abobrinha são escassos; porém, em plantas da mesma família, foram relatadas diminuições dos teores de nutrientes no fruto com o decorrer do tempo, como em pepino (Solis et al., 1988b) e melão (Belfort et al., 1988). Entretanto D`Andria et al. (1993) estudaram as modificações no estado nutricional do tomateiro, quando irrigado com água carbonatada, e observaram alterações na composição do fruto, de acordo com o período de colheita.

Tabela 18. Teores de nutrientes contidos em abobrinha cultivada com água carbonatada e cobertura plástica (M) determinado aos 64 DAT.

\begin{tabular}{|c|c|c|c|c|c|c|c|c|c|c|}
\hline \multirow[t]{2}{*}{ Trat, } & $\mathrm{N}$ & $\mathrm{P}$ & $\mathrm{K}$ & $\mathrm{Ca}$ & $\mathrm{Mg}$ & $\mathrm{S}$ & B & $\mathrm{Fe}$ & $\mathrm{Mn}$ & \multirow[t]{2}{*}{$\mathrm{Zn}$} \\
\hline & \multicolumn{5}{|c|}{$\mathrm{g} \mathrm{kg}^{-1}$} & \multicolumn{4}{|c|}{$\mathrm{mg} \mathrm{kg}^{-1}$} & \\
\hline 0 & 41,0 & 5,5 & 39,8 & 5,6 & 3,2 & 2,2 & 19,6 & 73,4 & 29, & 44,9 \\
\hline $0 \mathrm{M}$ & 38 & 5,8 & 47,4 & 5,2 & 3,1 & 2,1 & 29,0 & 76 , & 32,0 & 46,0 \\
\hline 300 & 42,4 & 5,8 & 45,9 & 5,0 & 2,6 & 2,1 & 25,9 & 63,7 & 29,4 & 46,9 \\
\hline $300 \mathrm{M}$ & 40,6 & 6,2 & 52,0 & 5,8 & 3,1 & 2,2 & 27,5 & 60,4 & 34 & 49,5 \\
\hline 600 & 40,9 & 5,8 & 49,0 & 4,9 & 3,3 & 2,3 & 19,8 & 83 & 35,9 & 47,7 \\
\hline $600 \mathrm{M}$ & 41,9 & 5,3 & 50,5 & 5,3 & 3,2 & 2,3 & 19,8 & 83,4 & 35,9 & 47,7 \\
\hline 900 & 40,7 & 6,0 & 52,0 & 5,6 & 3,5 & 2,9 & 25,7 & 83,4 & 34,7 & 53,0 \\
\hline $900 \mathrm{M}$ & 40,5 & 5,5 & 47,4 & 4,8 & 3,1 & 2,2 & 15,9 & 76,4 & 30,5 & 42,5 \\
\hline Média & 40,8 & 5,7 & 48,0 & 5,3 & 3,1 & 2,3 & 22,9 & 75,0 & 32,7 & 47,3 \\
\hline
\end{tabular}

Os teores dos nutrientes nos frutos observados no primeiro experimento, (Tabela 12) foram inferiores aos da primeira análise do segundo experimento (Tabela 17) e superiores, no geral, aos valores da segunda análise (Tabela 18). Apesar dessa 
flutuação, a seqüência de macronutrientes e micronutrientes presentes no fruto foi praticamente a mesma nos dois experimentos, independente dos tratamentos: $\mathrm{K}>\mathrm{N}>\mathrm{P}>\mathrm{Ca}>\mathrm{Mg}>\mathrm{S}>\mathrm{Fe}>\mathrm{Zn}>\mathrm{Mn}>\mathrm{B}$. De forma semelhante, Solis et al. (1988a) observaram, em plantas de pepino, que as quantidades de nutrientes exportados por meio das colheitas obedecia à seguinte ordem: $\mathrm{K}>\mathrm{N}>\mathrm{P}>\mathrm{Ca}>\mathrm{Mg}>\mathrm{Fe}>\mathrm{Zn}>\mathrm{Mn}>\mathrm{B}$. Furlani et al. (1978) verificaram, para a abobrinha, a mesma sequiência, exceto para o teor de cálcio que foi maior que o de fósforo.

Os teores de $\mathrm{Ca}$ nas folhas dos tratamentos irrigados com água carbonatada apresentaram problemas na análise, não sendo possível detectar relação com o teor de Ca nos frutos. Entretanto Solis et al. (1988c) verificaram, em pepino, uma relação linear entre o teor de Ca nas folhas e o acúmulo do elemento no fruto. Para os teores de $\mathrm{Mg}$, foram encontrados valores três vezes mais elevados no tratamento 300, em relação ao da testemunha, indicando boa translocação do elemento das folhas para os frutos. Segundo Malavolta et al. (1989), o Mg tende a competir com o Ca e K pelos sítios de adsorção no solo; entretanto, dentro da planta, ele não sofre restrição à sua translocação, sendo facilmente transportado das folhas para os frutos.

\subsubsection{Número de frutos e rendimento}

A primeira colheita foi realizada no dia 18 de outubro (29 DAT), prolongando-se até o dia 3 de dezembro de 2000 (74 DAT). Nesse período, colheitas diárias foram realizadas e praticamente não houve frutos não comerciais.

Na Tabela 19, são apresentados os número médio de frutos (frutos $\mathrm{ha}^{-1}$ ) e o rendimento $\left(\mathrm{kg} \mathrm{ha}{ }^{-1}\right)$ de abobrinha. Ambas as varáveis dependentes foram influenciadas, tanto pela cobertura plástica, quanto pela água carbonatada, sendo significativa a interação entre os dois fatores. Para o número de frutos, observa-se que a dose de $71 \mathrm{~kg} \mathrm{ha}^{-1}$ de $\mathrm{CO}_{2}$ em solo sem cobertura, produziu número maior que aquele obtido com a mesma dose em solo coberto. De forma semelhante, o rendimento de frutos foi significativamente superior na dose de $71 \mathrm{~kg} \mathrm{ha}^{-1} \mathrm{de} \mathrm{CO}_{2}$, em solo sem cobertura plástica, em relação ao rendimento obtido com a mesma dose em solo coberto. 
Para doses mais elevadas que $71 \mathrm{~kg} \mathrm{ha}^{-1}$ de $\mathrm{CO}_{2}$, os resultados foram pouco consistentes, variando conforme a dose utilizada, associada ou não à cobertura do solo.

Tabela 19. Número de Frutos (Frutos ha ${ }^{-1}$ ) e rendimento $\left(\mathrm{kg} \mathrm{ha}^{-1}\right)$ de abobrinha cultivada com água carbonatada em solo com e sem cobertura plástica.

\begin{tabular}{ccccc}
\hline $\begin{array}{c}\text { Dose de } \mathrm{CO}_{2} \\
\left(\mathrm{~kg} \mathrm{ha}^{-1}\right)\end{array}$ & \multicolumn{2}{c}{$\begin{array}{c}\text { Número de Frutos }(\text { Frutos ha } \\
\text { Sem Cobertura }\end{array}$} & Com cobertura & \multicolumn{2}{c}{ Rem Cobertura } & Com cobertura \\
\hline 0 & $129.444 \mathrm{a}$ & $136.667 \mathrm{a}$ & $41.156 \mathrm{a}$ & $42.047 \mathrm{a}$ \\
71 & $153.333 \mathrm{a}$ & $127.500 \mathrm{~b}$ & $51.790 \mathrm{a}$ & $39.228 \mathrm{~b}$ \\
199 & $127.778 \mathrm{~b}$ & $152.222 \mathrm{a}$ & $40.156 \mathrm{~b}$ & $46.538 \mathrm{a}$ \\
365 & $139.028 \mathrm{a}$ & $122.222 \mathrm{~b}$ & $45.564 \mathrm{a}$ & $38.400 \mathrm{~b}$
\end{tabular}

Para a variável, médias seguidas da mesma letra na horizontal, não diferiram estatisticamente entre si a 5\% de probabilidade pelo teste de Tukey.

Modelos de regressão para solo nu e solo coberto foram ajustados para o número de frutos e o rendimento (Tabela 20).

Tabela 20. Equações de regressão, relacionando o número de frutos (Frutos ha ${ }^{-1}$ ) e o rendimento de abobrinha às doses de $\mathrm{CO}_{2}$ em solo com e sem cobertura plástica.

\begin{tabular}{cccc}
\hline Variável & & Equações de regressão & $\mathrm{R}^{2}$ \\
\hline $\left.\begin{array}{c}\text { Número de frutos } \\
(\text { frutos ha }\end{array}{ }^{-1}\right)$ & s/cob. & $\mathrm{Y}_{\mathrm{e}}=131811,43+2256,2713^{\circ} \mathrm{X}^{0,5}-112,7697^{\circ} \mathrm{X}$ & 0,214 \\
& c/cob. & $\mathrm{Y}_{\mathrm{e}}=130179,76+176,0994 * \mathrm{X}-0,5281 * * \mathrm{X}^{2}$ & 0,489 \\
\hline Rendimento & s/cob. & $\mathrm{Y}_{\mathrm{e}}=42240,98+967,0355^{*} \mathrm{X}^{0,5}-48,1296^{*} \mathrm{X}$ & 0,192 \\
$\left(\mathrm{~kg} \mathrm{ha}^{-1}\right)$ & c/cob. & $\mathrm{Y}_{\mathrm{e}}=40145,72+48,9280^{*} \mathrm{X}-0,1430 * \mathrm{X}^{2}$ & 0,437 \\
& & & \\
\hline${ }^{\circ}, *, * *$, significativos a 10, 5 e 1\% de probabilidade, respectivamente, pelo teste t.
\end{tabular}

Para solo nu, estima-se um número máximo de frutos por ha de 142.514, com uma dosagem de $100 \mathrm{~kg} \mathrm{ha}^{-1}$ de $\mathrm{CO}_{2}$, enquanto, para solo coberto, estimam-se 144.860 frutos ha ${ }^{-1}$ com uma dosagem de $166,7 \mathrm{~kg} \mathrm{ha}^{-1}$ de $\mathrm{CO}_{2}$. 
Quanto ao rendimento, a eficiência máxima foi de $47.098 \mathrm{~kg} \mathrm{ha}^{-1}$, com uma dosagem de $100 \mathrm{~kg} \mathrm{ha}^{-1}$ de $\mathrm{CO}_{2}$, enquanto, para solo coberto, foi atingido o valor de $44.330,9 \mathrm{~kg} \mathrm{ha}^{-1}$, com uma dosagem de $171 \mathrm{~kg} \mathrm{ha}^{-1}$ de $\mathrm{CO}_{2}$.

Neste segundo experimento, as produções obtidas foram bastante superiores às do primeiro experimento e à média nacional. Isso deve estar relacionado à diferença de cultivar utilizada, ao maior período de colheita e, principalmente, às temperaturas do ar mais elevadas, que favoreceram o pleno desenvolvimento da cultura. Supostamente pelo mesmo motivo, a cobertura plástica sobre o solo não incrementou a produção, tal como o ocorrido no primeiro experimento. Porém, as doses de $\mathrm{CO}_{2}$ foram importantes em ambos os experimentos, embora, em termos relativos, tenham gerado resultados mais expressivos no período de temperaturas do ar mais baixas, visto terem sido empregadas menores doses do gás, para se atingirem produções bem superiores às do tratamento-testemunha.

Os resultados são consistentes com os de outras pesquisas, que demonstraram aumento de produção com o uso da água carbonatada (Mauney \& Hendrix, 1988; Novero et. al., 1991; Ibrahim, 1992; Pinto, 1997; Cararo, 2000; Guri et al., 1999). Entretanto, diferentemente, D`Andria et al. (1990) trabalharam com água carbonatada e cobertura plástica sobre o solo na cultura do tomate e encontraram efeito sobre a produção somente quando o gás foi associado à cobertura plástica.

Segundo Storlie \& Heckman (1996b), encontra-se na literatura uma série de variáveis, tais como o pH do solo, o pH da água de irrigação, a temperatura, a variedade utilizada e a cultura; associadas ao processo de carbonatação, podem promover resultados diferentes entre si. $\mathrm{O}$ não entendimento dessa interação entre a planta e os fatores ambientais e os resultados adversos é que tem limitado a recomendação da técnica aos agricultores. 


\subsection{Avaliação econômica}

Nos dois experimentos de campo, foram detectados efeitos na produção com o uso da água carbonata e da cobertura plástica. No primeiro experimento, onde foram observadas temperaturas médias do ar mais baixas, a associação das doses de $\mathrm{CO}_{2}$, via água de irrigação, e de cobertura plástica no solo trouxe benefícios à produção da cultura. A rentabilidade econômica foi avaliada, comparando-se a relação benefício custo do rendimento do tratamento testemunha $\left(9.328 \mathrm{~kg} \mathrm{ha}^{-1}\right)$ com a dos tratamentos de máximo valor de rendimento extraído da curva de produção em função das doses de $\mathrm{CO}_{2}$ para solo nu (11.821 $\left.\mathrm{kg} \mathrm{ha}^{-1}\right)$ e para solo com cobertura (15.435 $\left.\mathrm{kg} \mathrm{ha}^{-1}\right)$, sendo utilizados $84,5 \mathrm{~kg} \mathrm{ha}^{-1}$ de $\mathrm{CO}_{2}$ e 58,4 $\mathrm{kg} \mathrm{ha}^{-1}$ de $\mathrm{CO}_{2}$, respectivamente. A Tabela 21 apresenta a relação benefício custo para esse período.

Tabela 21. Valores da relação benefício/custo para a cultura da abobrinha cultivada com diferentes doses de $\mathrm{CO}_{2}$, aplicadas via água de irrigação, com e sem cobertura plástica, durante o primeiro experimento em Piracicaba.

\begin{tabular}{lcccc}
\hline \multicolumn{1}{c}{ Tratamento } & $\begin{array}{c}\text { Dose de } \mathrm{CO}_{2} \\
\left(\mathrm{~kg} \mathrm{ha}^{-1}\right)\end{array}$ & Menores & Médios & Maiores \\
\cline { 3 - 5 } & 0,0 & 0,34 & 0,53 & 0,71 \\
\hline Testemunha & 58,4 & 0,43 & 0,68 & 0,92 \\
Com cobertura & 84,5 & 0,57 & 0,90 & 1,21 \\
Sem cobertura & & & & \\
\hline
\end{tabular}

Pela Tabela 22, observa-se que somente quando são praticados os maiores preços para o tratamento com $\mathrm{CO}_{2}$ e sem cobertura, as receitas são maiores que o capital empatado no investimento. Porém é interessante ter em mente alguns aspectos: i) o período de colheita ocorreu por somente trinta dias, sendo que ele poderia ser prolongado por mais tempo, o que aumentaria a relação benefício custo; ii ) considerout se a produção somente de abobrinha tipo extra A, cujo preço é normalmente duas vezes inferior ao do tipo extra AA; iii) para a região de Piracicaba, o ano de 2000, 
especialmente durante a realização desse primeiro experimento, foi atípico em termos climáticos, o que interferiu nos resultados obtidos.

No segundo experimento com temperaturas do ar mais elevadas, a rentabilidade econômica foi avaliada, comparando-se a relação benefício custo do tratamento testemunha $\left(41.156 \mathrm{~kg} \mathrm{ha}^{-1}\right)$ com a dos outros tratamentos, sendo considerados os rendimentos de $47.098 \mathrm{~kg} \mathrm{ha}^{-1}$ para solo nu e de $44.331 \mathrm{~kg} \mathrm{ha}^{-1}$ para solo com cobertura, ambos extraídos da curva de produção, em função das doses de $\mathrm{CO}_{2}$. As doses do gás consideradas foram de $100,9 \mathrm{~kg} \mathrm{ha}^{-1}$ de $\mathrm{CO}_{2}$ e $171 \mathrm{~kg} \mathrm{ha}^{-1}$ de $\mathrm{CO}_{2}$, respectivamente para solo com cobertura e nu. A Tabela 21 apresenta a relação benefício/custo para esse período.

Tabela 22. Valores da relação benefício/custo para a cultura da abobrinha, cultivada com diferentes doses de $\mathrm{CO}_{2}$, aplicadas via água de irrigação, com e sem cobertura plástica durante o segundo experimento em Piracicaba.

\begin{tabular}{lcccc}
\hline Tratamento & Dose de $\mathrm{CO}_{2}$ & \multicolumn{3}{c}{ Considerando preços } \\
\cline { 3 - 5 } & $\left(\mathrm{kg} \mathrm{ha}^{-1}\right)$ & Menores & Médios & Maiores \\
\hline Testemunha & 0,0 & 1,48 & 2,34 & 3,14 \\
Com cobertura & 171,0 & 1,20 & 1,90 & 2,55 \\
Sem cobertura & 100,9 & 2,24 & 3,55 & 4,77 \\
\hline
\end{tabular}

No período quente, as receitas superaram o capital empatado no investimento, sendo que o emprego do $\mathrm{CO}_{2}$, sem a cobertura plástica, apresentou maior rentabilidade entre todos os tratamentos (Tabela 22). Isso ocorreu devido à melhor uniformidade da cultura e à menor incidência de pragas, o que permitiu prolongar a colheita por um período maior (45 dias), gerando aumento de produtividade. 


\section{CONCLUSÕES}

- Em temperaturas do ar mais baixas, a aplicação de $\mathrm{CO}_{2}$, via água de irrigação, associada à cobertura plástica sobre o solo, propiciou incremento na área foliar e na massa de material seco da parte aérea e das raízes, maior número de frutos e maior rendimento;

- Em temperaturas do ar mais baixas, o maior rendimento foi obtido com a dose de $58,4 \mathrm{~kg} \mathrm{ha}^{-1}$ de $\mathrm{CO}_{2}$, aplicada via água de irrigação, associada à cobertura plástica;

- Em temperaturas do ar mais elevadas, a aplicação de $\mathrm{CO}_{2}$, via água de irrigação, sem o uso da cobertura plástica sobre o solo, propiciou incremento na massa de material seco da parte aérea e das raízes, além de maior número de frutos e maior rendimento;

- Em temperaturas do ar mais elevadas, o maior rendimento foi obtido com a dose de $100 \mathrm{~kg} \mathrm{ha}^{-1}$ de $\mathrm{CO}_{2}$, aplicada via água de irrigação, sem cobertura plástica;

- O uso do dióxido de carbono, aplicado via água de irrigação, associado ou não à cobertura plástica do solo, mostrou viabilidade econômica no período de temperaturas mais elevadas;

- Plantas cultivadas sob irrigação com água carbonatada extraíram mais nutrientes do solo; 
- Os teores de $\mathrm{CO}_{2}$ aéreo apresentaram pequena elevação, quando se fez a aplicação da água carbonatada. 


\section{REFERÊNCIAS BIBLIOGRÁFICAS}

ABDUL-BAKI, A.; SPENCE,C. ; HOOVER, R. Black polyethylene mulch doubled yield of fresh-market field tomatoes. Hortscience, v.27, n.7, p.787-789, 1992.

ACOCK,B.; ACOCK,M.C.; PASTERNAK,D. Interactions of $\mathrm{CO}_{2}$ enrichment and temperature on carbohydrate production and accumulation in muskmelon leaves. Journal of the American Society for Horticultural Science, v.115, n.4, p.525$529,1990$.

ALLEN, L.H. Plant response to rising carbon dioxide and potential interactions with air pollutants. Journal of Environmental, v.19,p.15-34, 1990.

ALLEN, L.H.; DRAKER,B.G.; ROGERS,H.H. et al. Fields techniques for exposure of plants and ecosystems to elevated $\mathrm{CO}_{2}$ and other trace gases. Critical Reviews in Plant Science,v.11,n.2/3, p.85-119, 1992

AMTHOR,J.S. Perspective on the relative insignificance of increasing atmospheric $\mathrm{CO}_{2}$ concentration to crop yield. Field Crops Research,v.58, p. 109-127, 1998.

ARAÚJO, W.F.; BOTREL, T.A.; OLIVEIRA de, R.F. et al. Estimativa da área foliar de abobrinha usando método não destrutivo. Horticultura Brasileira, v.18, p.327-328, 2000.

ARTECA, R.N. ; POOVAIAH, B.W. Absorption of ${ }^{14} \mathrm{CO}_{2}$ by potato roots and its subsequent translocation. Journal of the American Society Horticultural Science, v.107, n.3, p.398-401, 1982.

ARTECA, R.N. ; POOVAIAH, B.W.; SMITH, O.E. Changes in carbon fixation, tuberization, and growth induced by $\mathrm{CO}_{2}$ applications to the root zone of potato plants. Science, v. 205, n.21, p. 1279-1280, 1979. 
AYRES,R.S. ; WESTCOT,D.W. A qualidade da água na agricultura. Trad. de H.R. Gheyi et al. Campina Grande: UFPB, 1991. 218p. (FAO. Estudos de Irrigação e Drenagem,29).

BAKER,R. Trichoderma spp, as plant-growth stimulants. Critical Reviews in Biotechnology, v.7, n.2, p.97-106,1988.

BARON,J.J. ; GORSKI,S.F. Response of eggplant to a root environment enriched with $\mathrm{CO}_{2}$. HortScience, v. 21, p.495-498,1986.

BELFORT,C.C.; HAAG,H.P.; MATSUMOTO,T. et al. Nutrição mineral de hortaliças. Acumulação de matéria seca e recrutamento de macronutrientes pelo Melão (Cucumis melo . cv. Valenciano Amarelo CAC) cultivado em Latossolo Vermelho Amarelo em Pressidente Venceslau, SP. In: HAAG, H.P., MINAMI,K. Nutrição mineral de hortaliças. Campinas: Fundação Cargill, 1988. p.293-349.

BERNARDO, S. Manual de irrigação. Viçosa: UFV, 1995.657p.

BHELLA,H.S. Effect of trickle irrigation and black mulch on growth, yield, and mineral composition of watermelon. Hortscience, v.23, n.1, p.123-125, 1988.

BHELLA,H.S.; KWOLEK,W.F. The effects of trickle irrigation and plastic mulch on zucchini. Hortscience, v.19, n.3, p.410-411, 1984.

BUWALDA,J.G.; FREEMAN,R.E. Effects of phosphorus fertilizer level on phosphorus accumulation, growth and yield of hybrid squash in the field. Scientia Horticulturae, v.34, p.201-210, 1988.

CAMARGO FILHO,W.P.; MAZZEI ,A.R. Abastecimento de legumes: tendência de preços. Informações Econômicas, v.30, n.10, p.35-49, 2000.

CAMARGO, L.S. As hortaliças e seu cultivo. Campinas: Fundação Cargill, 1981. $321 \mathrm{p}$.

CARARO, D.C. Efeito de diferentes lâminas de água na presença e ausência de $\mathrm{CO}_{2}$ injetado na água de irrigação sobre a cultura do tomate (lycopersicon esculentum Mill,) cultivado em estufa. Piracicaba, 2000. 70p, Dissertação (Mestrado) - Escola Superior de Agricultura "Luiz de Queiroz", Universidade de São Paulo. 
CARDOSO, A.I.I. A cultura da abobrinha-de-moita. In: GOTO, R. Produção de hortaliças em ambiente protegido: condições subtropicais. Botucatu: UNESP, 1998.p.105-135.

CHAUDHURI,U.N.; KIRKHAM,M.B.; KANEMASU,E.T. Root growth of winter wheat under elevated carbon dioxide and drought. Crop Science, v. 30, p. 853-857, 1990.

CHRISTOFIDIS,D. Os recursos hídricos e a prática da irrigação no Brasil e no mundo. ITEM, n.49, p.8-13, 2001.

CLOUGH,G.H.; LOCASCIO,S.J.; OLSON,S.M. Mineral concentration of yellow squash responds to irrigation method and fertilization management. Journal of the American Society for Horticultural Science, v.117, n.5, p. 725-729. 1992.

COCUCCI, S.; COCUCCI,M.; POMA TRECCONI,C. Effect of water deficit on the growth of squash fruit. Plant physiology, v.36, p.379-382, 1976.

COMPANHIA DE ABASTECIMENTO DO ESTADO DE SÃO PAULO. http://www.ceagesp.com (12 Out. 2000).

D’ANDRIA, R.; MAGLIULO,V.; MAGGIO A. et al. Soil and plant nutrient modifications in response to irrigation with $\mathrm{CO}_{2}$ enriched water on tomato. Acta Horticulturae, n. 335, p.557-562, 1993.

D’ANDRIA, R.; NOVERO, R.; SMITH, D.H. Drip irrigation of tomato using carbonated water and mulch in colorado. Acta Horticulturae, n. 278, p. 179-185, 1990.

DERWERKEN VAN, J.E.; WILCOX-LEE,D. Influence of plastic and type and frequency of irrigation on growth and yield of bell pepper. HortScience, v.23, n.6, p.985-988, 1988.

DOORENBOS,J. ; PRUITT,W.O. Necessidades hídricas das culturas. Trad. de H.R.Gheyi et al. Campina Grande: UFPB, 1997. 204p. (Estudos FAO. Irrigação e Drenagem, 24).

DRAKE, B.G.; JACOB,J.; GONZÁLEZ-MELER, M.A. Photosynthesis, respiration and global climate change. Cambridge: Cambridge University Press, 1998. 376p. (Photosynthesis. A comprehensive treatise). 
ENOCH,H.Z.; OLESEN, J.M. Plant response to irrigation with water enriched with carbon dioxide. New Phytology, v. 125, n.54, p.249-258, 1993.

EPSTEIN, E. Nutrição mineral de plantas: princípios e perspectivas. São Paulo: EDUSP; Livros Técnicos e Científicos, 1975. 341p.

ESCOLA SUPERIOR DE AGRICULTURA “LUIZ DE QUEIROZ”. Departamento de Ciências Exatas. Base de dados. http://ce.esalq.usp.br/dce/postocon.htm (10 out. 2001).

FILGUEIRA,F.A.R Novo manual de olericultura: agroteconologia moderna na produção e comercialização de hortaliças. Viçosa: UFV, 2000. 402p.

FONTES,R.R.; LIMA, J. A. Nutrição mineral e adubação do pepino e da abóbora, In: FERREIRA,M.E.; CASTELLANE,P.D.; CRUZ, M.C.P. Nutrição e adubação de hortaliças. Piracicaba: POTAFOS, 1993. p. 281-300.

FURLANI,A.M.C.; FURLANI,P.R.; BATAGLIA,O.C. et al. Composição mineral de diversas hortaliças. Bragantia,v.37, n.5, p.34-44, 1978.

GARNAUD,J.C. The intensification of horticultural crop production in the mediterranean basin by protected cultivation. Rome: FAO, 1974. 148p.

GIFFORD,R.M. Growth and yield of $\mathrm{CO}_{2}$-enriched wheat under water-limited conditions. Australian Journal of Plant Physiology, v. 6, p.367-378, 1979.

GOMIDE,R.L. Monitoramento para manejo da irrigação:instrumentação, automação e métodos. In: FARIA, M.A. Manejo da irrigação. Lavras: Ed. Suprema Gráfica, 1998. cap. 2, p.133-280.

GURI,S.; MARFA,O.; SAVÉ,R. Efecto de la irrigación carbónica en la producción de un cultivo de pimiento.Barcelona: IRTA, Departamento de Tecnologia Hortícola, 1999. 6p.

HALL,D.O.; RAO,K.K. Fotossíntese. São Paulo: E.P.U., 1980. 89p. (Coleção Temas de Biologia, 10)

HARPER,L,A.; BAKER,D.N.; BOX,J.E. et al. Carbon dioxide and the photosynthesis of field crops: A metered carbon dioxide release in cotton under field conditions. Agronomy Journal, v. 65, p.7-11, 1973. 
HARTZ, T.K. Water management in drip-irrigated vegetable production. HortTechnology, v.6, n.3, p.165-167, 1996.

HARTZ,T.K. ; BAAMEUR A.; HOLT,D.B. Carbon dioxide enrichment of high-value crops under tunnel culture. Journal of the American Society for Horticultural, v.116, n.6, p.970-973, 1991.

HARTZ,T.K. ; HOCHMUTH,G.J. Fertility management of drip-irrigated vegetables. HortTechnology, v. 6, n.3, p.168-172, 1996.

HARTZ,T.K.; HOLT,D.B. Root-zone Carbon Dioxide Enrichment in field does not improve tomato or cucumber yield. HortScience, v. 26, n.11, p.1423, 1991.

HOPEN, H.J.; OEBKER,N.F. Mulch effects on ambient carbon dioxide levels and growth of several vegetables. HortScience, v. 10, n.2, p. 159-161, 1975.

IBARRA, L.; FLORES,J.; DÍAZ-PÉREZ,J.C. Growth and yield of muskmelon in response to plastic mulch and row covers. Scientia Horticulturae, v.87, p.139-145. 2001

IBRAHIM, A. Response of plant to irrigation with $\mathrm{CO}_{2}$ enrichment water. Acta Horticulturae, n.323, p.205-214. 1992

IDSO, K.E.; IDSO, S.B. Plant response to atmospheric $\mathrm{CO}_{2}$ enrichment in the face of environmental constraints: a review of the past 10 years research. Agricultural and Forest Meteorology, v.69,p.153-203, 1994.

INFORME AGROPECUÁRIO. Curcubitáceas. EPAMIG, v.8, n.85, jan/1982, 84p.

INSTITUTO BRASILEIRO DE GEOGRAFIA ESTATÍSTICA, 2001. Censo agropecuário de 1996. http://www.sidra.ibge.gov.br/bda/ tabela/protabl.asp (27 maio. 2001).

JONES, M.B. Plant microclimate, In: HALL,D.O. ; SCURLOCK,J,M.O.; BOLHÀRNORDENKAMPF, H.R. et al. (Ed.) Photosynthesis and production in changing environment. London: Chapman and Hall, 1993. v.7, p.47-64.

KELLER, J.; BLIESNER,R.D. Sprinkle and trickle irrigation New York: Ed. International Thomson, 1990. cap. 3, p.453-477: Trickle irrigation. 
KIMBALL, B.A., La MORTE,R.L.; SEAY,R.S. et al. Effects of free air $\mathrm{CO}_{2}$ enrichement on energy balance and evapotranspiration of cotton. Agricultural and Forest Meteorology, v.70, n.1/4, p.259-278, 1994.

KLOSOWSKI,E.S.; LUNARDI, D.M.C.; SANDANIELO,A. Determinação do consumo de água e do coeficiente de cultura da abóbora na região de Botucatu, SP. Revista Brasileira de Engenharia Agrícola e Ambiental, v.3, n.3, p.409-412, 1999.

LAMONT Jr., W.J. What are the components of a plasticulture vegetable system? HortTechnology, v. 6, n.3, p. 150-154, 1996.

LOCASCIO,S.J.; SMAJSTRLA, A.G. Water application scheduling by pan evaporation for drip-irrigated tomato. Journal of the American Society for Horticultural Science, v.121, n.1, p. 63-68, 1996.

LORENZ,O.A.; MAYNARD,D.N. Knott's handbook for vegetable growers. New York: Jonh Willey, 1988. 456p.

LUNARDI, D.M.C.; KLOSOWSKI,E.S.; SANDANIELO,A. Consumo hídrico e coeficiente de cultura da abóbora italiana na região de Botucatu-SP. Revista Brasileira de Agrometeorologia, v.7, n.2, p.179-182, 1999.

MAKISHIMA,N. ; MIRANDA,J.E.C. Cultivo do tomate (lycopersicon esculentum Mill,). Brasília: EMBRAPA, CNPH, 1992. 22p. (Instrução Técnica, 11).

MALAVOLTA, E. Manual de química agrícola. São Paulo: Ed. Ceres, 1976. 528p.

MALAVOLTA, E; VITTI,G.C.; OLIVEIRA,S.A. Avaliação do estado nutricional das plantas: princípios e aplicações. Piracicaba: POTAFOS, 1989. 201p.

MAROTO,J.V. Horticultura herbacea especial. 4. ed. Madri: Ed. Mundi-Prensa, 1995. $611 \mathrm{p}$.

MAUNEY,J.R.; HENDRIX, D.L. Responses of glasshouse grown cotton to irrigation with carbon dioxide-satures water. Crop Science, v. 28, p.835-838, 1988.

MILLS,H.A.; JONES JUNIOR, J.B. Plant analysis handbook II a practical sampling, preparation, analysis and interpretation guide. Georgia: Micromacro, 1996. 422p.

MOORE, F.D. Potential for irrigation with carbon dioxide. Acta Horticulturae, n. 278, p.171-178, 1990. 
MORMENEO,I. ; CANTAMUTTO,M.A. Modification of soil temperature for a mulch effect. Revista Brasileira de Agrometeorologia, v.7, n.2, p.169-172, 1999.

MUDRIK, V. A.; ROMANOVA, A. K.; IVANOV, B. N. et al. Effect of increased $\mathrm{CO}_{2}$ concentration on growth, photosynthesis and composition of pisum sativum L. plant. Russian Journal of Plant Physiology, v.44, n.2, p,165-171, 1997.

NAKAYAMA,F.S.; BUCKS,D.A. Using subsurface trickle system for carbon dioxide enrichment. In: NATIONAL AGRICULTURAL PLASTIC CONGRESS, 15, Tucson, 1980, p.13-17.

NOVERO,R.; SMITH, D.H.; MOORE, F.D. et al. Field-Grown tomato response to carbonated water application. Agronomy Journal, v. 83, p. 911-916, 1991.

OMETTO,J.C. Registros e estimativas de parâmetros meteorológicos da região de Piracicaba, SP. Piracicaba: FEALQ, 1989. 76p.

PARIS,H.S. Summer squash: history, diversity and distribution. HortTechonology, v.6, n.1,p.6-13, 1996.

PAVAN,M.A. ; MIYAZAWA, M. Análises químicas de solo: parâmetros para interpretação. Londrina: IAPAR, 1996. 46p. (Circular IAPAR, 91).

PEREIRA, A.R.; VILLA NOVA,N.A.; SEDIYAMA,G.C. Evapo(transpi)ração. Piracicaba: FEALQ, 1997. 183p.

PINTO,J.M. Aplicação de dióxido de carbono via água de irrigação em meloeiro. Piracicaba, 1997. 82p. Tese (Doutorado) - Escola Superior de Agricultura Luiz de Queiroz, Universidade de São Paulo.

PIZARRO,F. Riegos localizados de alta frecuencia. Madri: Mundi-Prensa, 1986. 461p.

REICHARDT, K. Capacidade de campo. Revista Brasileira de Ciência do Solo, v. 12, p.211-216, 1988.

REINERT,R.A.; EASON,G.; BARTON,J. Growth and frutiing of tomato as influenced by elevated carbon dioxide and ozone. New Phytlotosy, v. 137, p.411-420, 1997.

REZENDE, F.C. Resposta de plantas de pimentão (Capsicum annum L.) à irrigação e ao enriquecimento da atmosfera com $\mathrm{CO}_{2}$ em ambiente protegido. Piracicaba, 2001. 107p. Tese (Doutorado) - Escola Superior de Agricultura “Luiz de Queiroz”. 
SAMPAIO,R. A. Produção, Qualidade dos frutos e teores de nutrientes no solo e no pecíolo do tomateiro, em função da fertirrigação potássica e da cobertura plástica do solo. Viçosa, 1996. 117p. Tese (Doutorado) - Universidade Federal de Viçosa.

SANDERS,D.C. Using plastic mulches and drip irrigation for vegetable production. 1996.http://www.ces.ncsu.edu/depts/hort/hil/hil-33.html (9 jun. 2000).

SARRUGE,J.R.; HAAG,H.P. Análise químicas em plantas. Piracicaba: ESALQ, Departamento de Química, 1974. 56p.

SHANI,M. La fertilización combinada com el riego. Tel Aviv: Ministério de Agricultura: Serviço de Extensión, 1981. 36p.

SILVA, U.D.; LOUREIRO, B.T.; BERNARDO, S. et al. Efeitos dos emissores de água “Trorion" e "Gotasa"sobre a produção de abobrinha italiana (Cucurbita pepo L.). Revista CERES, v. 35, n.202, p.529-541, 1988.

SILVA,W.L.C.; MAROUELLI, W.A. Manejo da irrigação em hortaliças no campo e em ambiente protegidos. In: FARIA, M.A. Manejo da irrigação. Lavras: Ed. Suprema, 1998. cap. 5, p.311-348.

SIONIT,N.; STRAIN,B.R.; HELLMERS,H. Effects of different concentrations of atmosferic $\mathrm{CO}_{2}$ on growth and yield components of wheat. Journal of Agricultural Science, v. 70, p. 335-339, 1981.

SOLIS,F,A.M.; HAAG, H.P.; MINAMI,K. Desenvolvimento dos frutos da cultura do pepino (Cucumis sativus L,) var, aoadi e exportação dos nutrientes através da colheita, In: HAAG, H.P.; MINAMI,K. Nutrição mineral de hortaliças. Campinas: Fundação Cargill, 1988a. p. 237-251.

SOLIS,F,A.M.; HAAG, H.P.; MINAMI,K. et al. Concentração de nutrientes na cultura do pepino (Cucumis sativus L.) var. aoadi cultivado em condições de campo. In: HAAG, H.P.; MINAMI,K. Nutrição mineral de hortaliças. Campinas: Fundação Cargill, 1988b.p. 183-235.

SOLIS,F.A.M.; HAAG, H.P.; MINAMI,K. et. al. Acumulação de nutrientes na cultura do pepino (Cucumis sativus L.) var. aoadi cultivado em condições de campo, In: HAAG, H.P.; MINAMI,K. Nutrição mineral de hortaliças. Campinas: Fundação Cargill, 1988c. p.235-241. 
SOUZA, L.D. ; REICHARDT, K. Estimativa da capacidade de campo. Revista Brasileira de Ciência do solo, v. 20, p.183-189, 1996.

STANSELL, J.R.; SMITTLE,D.A. Effects of irrigation regimes on yield and water use of summer squash. Journal of American Society of Horticultural Science, v. 117, n.5, p.717-720, 1992.

STORLIE, C.A.; HECKMAN, J.R. Bell pepper yield response to carbonated irrigation water. Journal of Plant Nutrition, v. 19, n.10/11, p.1477-1484, 1996a.

STORLIE, C.A.; HECKMAN, J.R. Soil, plant, and canopy responses to carbonated irrigation water. HortTechnology, v. 6, n.2, p.111-114, 1996 b.

SWEENEY,D.W.; GRAETZD.A.; BOTTCHER,A.B. et al. Tomato yield and nitrogen recovery as influenced by irrigation method, nitrogen source and mulch. HortScience, v.22, p.27-29, 1987.

TRANI, P.E.; RAIJ,B.van. Hortaliças. Boletim Técnico. IAC, n. 100, p. 157-165, 1996.

TSEKLEEV,G.; BOYADJIEVA,N.; SOLAKOV, Y. et al. Influence of photoselective mulch films on tomatoes in greenhouses. Plasticulture, v.95, p.45-49, 1993.

VESSEY,J.K.; HENRY,L.T.; RAPER Jr.; C.D. Nitrogen nutrition and temporal effects of enhanced carbon dioxide on soybean growth. Crop Science, v.30, n.2, p.287294, 1990.

VITOUSEK,P.M. Can planted forests counteract increasing atmospheric carbon dioxide?. Journal of Environmental Quality, v.20, n.2, p.348-354, 1991. 